\title{
Tesis \\ Kosovo: una visión desde el Neorrealismo Internacional
}

M aestrando: Leonardo Javier Balmaceda 2001

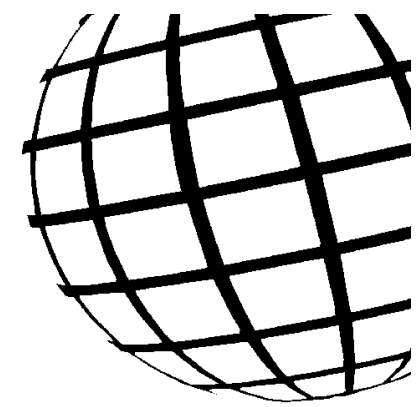




\section{Agradecimientos}

La presente tesis no pudo haberse realizado sin la indispensable participación, colaboración y generosa aportación de las siguientes personas:

El apoyo moral y aliento continuo del Dr. Norberto Consani, fue un incentivo muy importante para llevar adelante la presente investigación.

La guía e innumerables comentarios útiles del Lic. Roberto Miranda, sobre la investigación histórica y teórica fue indispensable, para todo el análisis del caso hasta llegar a cobrar forma.

Mucho me beneficiaron las sugerencias y aportes del Dr. Eduardo Barragán Thenon, sobre todo en la confección y materialización del proyecto de Tesis.

Mi familia, como siempre, fue una buena consejera y un indispensable apoyo moral.

Leonardo Javier Balmaceda 


\section{Introducción:}

La finalización de la pugna ideológica entre Estados Unidos y la Unión Soviética dio por terminada la vigencia del Sistema Bipolar, que había regido entre los años 1947-1989. Como consecuencia de ello se produjo un reordenamiento del "Orden Internacional", dando lugar a la aparición de grandes potencias o actores polares como Alemania y Japón que desarrollaron su capacidad para ser competidores y desafiar, como lo afirma Luis Dallanegra Pedraza ${ }^{1}$, en ciertos "ejes de poder" a los anteriores líderes de bloque. En especial en el eje económico y financiero.

El cambio en la importancia de los ejes de poder, provocó una dispersión del "poder" y una mayor libertad de maniobras tanto política, económica y financiera en comparación al sistema bipolar. Este cambio generó la gestación de un "Nuevo Orden Internacional" con característica Multipolar.

La elección del tema parte de la ausencia de un análisis del conflicto desde una visión de la teoría del realismo estructural sobre la problemática internacional originada en la ex Yugoslavia, que constituye un importante acontecimiento en la historia de las relaciones internacionales y que evidencia la necesidad de redefinir y lograr un sistema de seguridad internacional.

Así como también puso de manifiesto la forma en que una organización internacional de defensa, como es la Organización del Tratado del Atlántico Norte (OTAN) ha tomado la iniciativa haciendo caso omiso a los procedimientos y reglamentos acordados en la Organización de las Naciones Unidas (Capítulo VII de la Carta de la ONU)

La crisis de Kosovo demostró, por un lado, la importancia que los Estados dan a su capacidad para resolver o tratar de contener los conflictos que amenacen o afecten sus intereses vitales, y por otro lado, evidenció que las "potencias polares" no dudan en proclamar como discurso de legitimación la protección de los Derechos Universales del Hombre y el ejercicio de sus libertades fundamentales para lograr la justificación de sus acciones ante la opinión mundial.

La guerra de Kosovo también refleja las amenazas o crisis, que deben enfrentar el nuevo orden internacional, representadas en la desintegración y desmembramiento de los Estadosnación.

A partir de la situación planteada, la presente tesis, tiene como eje central analizar la participación Estados Unidos en la guerra de Kosovo, desde la perspectiva del realismo estructural, tratando de sugerir un modelo explicativo/predictivo de respuestas esperables por parte de los Estados Unidos ante conflictos que surjan en un contexto similar al de Kosovo.

La elección de la teoría del realismo estructural, a su vez sirve como paradigma de análisis Estados Unidos, considerado como un actor racional para establecer su posición e intereses geopolíticos que motivaron su participación en el conflicto. Para justificar la elección del realismo estructural se analizan otras teorías con el fin de señalar las falencias de estas sobre la base de la explicación del conflicto.

De esa manera, se demuestra por qué los postulados del Realismo Estructural, permiten una explicación clara y un análisis más satisfactorio sobre la conducta de Estados Unidos en el

\footnotetext{
${ }^{1}$ Dallanegra Pedraza, Luis (1998) "El Orden Mundial del Siglo XXI”. Buenos Aires. De la Universidad, p. 18. Subsistema dominante o actor polar, es aquél actor que ha alcanzado, por su capacidad-cualquiera sea la forma en que la haya demostrado: militar o económica - el rango de generador de reglas o pautas direccionadoras, de manera individual o compartida con otros "subsistemas dominante" o actores "polares".
} 
conflicto, para establecer cuál es la razón de que, Estados Unidos (única potencia con alcance mundial) tenga la necesidad de asegurar la gobernabilidad global.

Este contexto internacional nos coloca frente a la formulación del problema principal de la presente tesis, el cual reside, en que el actual escenario universal se caracteriza por la ausencia de un único pensamiento político, ideológico, religioso y cultural, que permita enunciar un discurso aglutinado y homogéneo capaz de canalizar las distintas aspiraciones que coexisten en esta época de cambios vertiginosos favorecidos por la globalización.

El marco teórico del análisis estará basado fundamentalmente en las premisas del realismo estructural, que explica el comportamiento de los Estados a través de la comprensión de la naturaleza del sistema internacional, el que estaría condicionado por los cambios en las capacidades relativas de los Estados. Las capacidades se refieren principalmente a los recursos económicos, a la productividad de los Estados y a su poderío militar.

La caída del comunismo no supuso el surgimiento de un pensamiento homogéneo, debido a que la globalización puede interpretarse como un acontecimiento estructural de la época, lo que no implica que su ideología (neoliberal) sea aceptada como un discurso globalizado.

La guerra de Kosovo, constituye una muestra de la manera en que Estados Unidos instrumenta sus recursos y capacidades a fin de lograr la necesaria legitimación internacional para concretar su planificación geoestratégica, con la menor oposición cuestionamientos y suspicacias posibles, por parte de la Comunidad Internacional y en especial de sus aliados.

El acontecer internacional evidencia una transformación económica, política y social en general. En esta transición hacia un Nuevo Orden Internacional, va perdiendo coherencia la diferenciación entre lo nacional y lo internacional como estamentos separados e incompatibles. Lo que nos lleva a la determinación del problema secundario, el que esta constituido por el estudio y análisis de la articulación de la variable individual: Kosovo; de la variable relacional: Kosovo con respecto a Estados Unidos, la Unión Europea y la OTAN; y de la variable contextual: Kosovo en consideración al acontecer histórico y la actualidad.

Del estudio y análisis de la articulación de las variables se determinara las repercusiones y relaciones existente entre la estrategia de las potencias polares comprometidas en el conflicto con las instituciones encargadas de velar por la paz y la seguridad internacional.

También se analizara la consecuencia que tuvo la crisis en el Orden Internacional y en el plano nacional de las naciones comprometidas. En consideración a sus respectivos sistemas políticos y jurídicos internos, su colisión, superposición y articulación con los objetivos de las políticas domésticas y externas de los Estados.

En este contexto mundial se le presenta a los Estados Unidos, la necesidad de asegurar la gobernabilidad global, para resguardar los objetivos planteados en su geoestrategia.

Así mismo, se comprobara la validez de los conceptos de la teoría neorrealista como herramienta de análisis para hallar una posible explicación a la guerra de Kosovo y, para tratar de establecer cuáles serían las respuestas esperables de las potencias polares, ante conflictos similares. 


\section{Capítulo 1 \\ El fracaso de Rambouillet y la intervención armada.}

\section{Ubicación geográfica:}

El territorio conocido como los "Balcanes", constituye la zona más oriental de las penínsulas mediterráneas del sur de Europa, limitadas al este con los mares Negro y Mármara, al sudeste y sur con el mar Egeo y al oeste con el Adriático y Jónico, su extensión es de 510.000 $\mathrm{km}$ cuadrados. Está habitada por distintos grupos étnicos entre los que se encuentran Serbios, Macedonios, Eslovenos, Montenegrinos, Albaneses, Húngaros, Ucranianos, Rusos, Rumanos, Eslovaco, Alemanes, Checos e Italianos.

En el aspecto religioso encontramos, como las corrientes más importantes, a creyentes cristianos ortodoxos, mahometanos y católicos romanos.

La provincia serbia de Kosovo ("provincia serbia", ya que se halla bajo la jurisdicción territorial de Serbia) limita con Macedonia, Montenegro y Albania, comprende una región de $11.000 \mathrm{~km}$ cuadrados, tiene 2 millones de habitantes aproximadamente, donde la mayoría albanesa constituye el $90 \%$, y una minoría serbia que configura el 7 a $8 \%$ de la población.

\section{Antecedentes históricos:}

\section{Antecedentes remotos:}

La mayoría de los analistas, sobre los origines de los conflictos en la región de los Balcanes, coinciden en que ya desde la Edad Media, ocurrieron diferentes invasiones hasta la constitución del Imperio Bizantino que los serbios invadieron en el siglo XIV, estableciendo allí su sitio espiritual más relevante.

En el año 1389, los turcos otomanos vencieron a los serbios en Kosovo Polje, a partir de ese momento el lugar se considera como la cuna de la tradición del nacionalismo serbio. Los turcos, posteriormente, invadieron toda la región de los Balcanes, luego este territorio pasó a ser controlado, por albaneses y por bosnios de fe musulmana en su mayoría.

El 22 de septiembre de 1815, tuvo lugar un Congreso en Viena en el que concurrieron representantes de las principales potencias europeas de entonces (Imperio Austro-Húngaro, Prusia, Francia, Gran Bretaña y Rusia), donde se discutió no sólo el destino de Francia, tras el derrumbe del Imperio Napoleónico, sino también como se reconstruiría política y territorialmente a Europa.

El resultado de aquella negociación llevada no fue relevante para la situación de los Balcanes, que seguía en poder del Imperio Turco-Otomano pero que sirvió para que comenzara a mostrar indicios de debilidad.

En 1878 en el Congreso de Berlín, como consecuencia de la guerra Ruso-Turca, lograron su independencia Rumania, Serbia y Montenegro. Así empezó la decadencia de los imperios dominantes en la región; surgían los movimientos independentistas y nacionalistas que buscaban el apoyo de la gente para materializar las identidades étnicas en los estados soberanos.

Si bien Serbia se convirtió en un país de tamaño reducido ( $5000 \mathrm{~km}$ cuadrados, con una estructura arcaica, con una población de dos millones de habitantes, sin acceso al mar y sin líneas férreas) con Belgrado, como su ciudad más importante, el Imperio Otomano siguió dominando el territorio albanés.

En 1908 Bulgaria se independizó de Turquía. Este acontecimiento da ímpetu a los intentos independentistas más al sur y en 1912 Bulgaria, Grecia, Serbia y Montenegro, con la asistencia y apoyo de Rusia, declaran la guerra a Turquía.

La derrota de Turquía le permite a los Serbios recuperar por primera vez desde la Edad Media el control sobre Kosovo, este territorio comenzó a denominarse "Vieja Serbia", este dominio territorial choca con las aspiraciones expansionistas de los Albaneses que querían a 
Kosovo para constituir un Estado más grande y con el cual pasarían a constituir la "Gran Albania".

Los serbios, evitaron el proyecto de construcción de la Gran Albania con el apoyo de otros estados de origen eslavo que se unieron para expulsar a los turcos de las regiones de Europa del Este, el apoyo de Rusia fue el más importante.

Rusia continuó su apoyo a Serbia para llevar adelante la constitución de la "Gran Serbia". Los serbios ambicionaron para ello los territorios de Bosnia y de Croacia, y muy especialmente, la localidad de Krajina, pues allí habitaban numerosos serbios. La razón del apoyo ruso a las aspiraciones serbias tenía un fundamento estratégico, ya que con ello se buscaba contener tanto la influencia del Imperio Astro-Húngaro como el del Imperio Turco-Otomano.

Finalizada la primera guerra en los Balcanes, se celebró un acuerdo de paz en Londres, en donde se estableció la división de los territorios ocupados por los turcos entre todos los estados balcánicos, esto produjo la oposición de los serbios con lo acordado pues ellos ambicionaban el territorio perteneciente a Albania, para tener la ansiada salida al mar, razón por demás fuerte como para que Albania conservara su territorio.

Las razones geopolíticas pesaron a favor de Albania para que la misma conservara su integridad territorial, este acontecimiento fue apoyado por Austria, Alemania y Gran Bretaña. Estos países no querían que Rusia aumentara su influencia en la región a través de Serbia.

También Bulgaria había demostrado su disconformidad, porque aspiraba apoderarse de Macedonia, y como la mayor parte del territorio quedó en poder de los serbios, se produjo una segunda guerra balcánica (1913) pues Bulgaria atacó a Serbia. Los griegos, rumanos y turcos apoyaron a Serbia. Vencidos los búlgaros fueron obligados a entregar casi la totalidad del territorio que habían obtenido en la primera guerra.

En ambas guerras, Serbia, siempre resulto ser la nación más beneficiada, esto despertaba el recelo del Imperio Austro-Húngaro que estaba decidido a evitar la realización del proyecto de construcción de la "Gran Serbia".

La animosidad y desconfianza entre Serbia y Austro-Hungría se profundizaron con la muerte del Archiduque Franz Ferdinand, heredero de la corona imperial, ocurrida el 28 de junio de 1914, en manos de Gavrilo Princip miembro de la organización nacionalista conocida como "mano negra". En consecuencia Austria - Hungría, con el apoyo de Alemania, le declarara la guerra a Serbia acusándola de ser la instigadora del asesinato, puntapié que iniciaría la Primera Guerra Mundial (1914-1918).

Como se dijo el impero Austro-Húngaro le declara la guerra a Serbia, así se inicia una secuencia de intervenciones de otros Estados que por causa de las alianzas existentes produjeron un agravamiento del conflicto, que Ilevaron a Rusia a auxiliar a Serbia, a Alemania a apoyar a los Austro-Húngaros; y más tarde se sumaron también, en apoyo a los serbios, Francia, Gran Bretaña y Estados Unidos.

Luego de finalizada la Primera Guerra Mundial y de producida la disolución del Imperio Otomano, surge el Reino de los Serbios, Croatas y Eslovenos, que en 1929 pasó a denominarse Yugoslavia.

La integridad de Yugoslavia desaparece en 1941, durante la Segunda Guerra Mundial, a causa de una fragmentación política del territorio, dominado por los nazis. Yugoslavia aparece ahora como un Estado republicano y federal bajo el régimen comunista del mariscal Tito.

\section{b. Antecedentes recientes}

En el año 1974 se promulgó una nueva constitución en Yugoslavia, donde se reconocía a Kosovo y a la Vojvodina la condición de regiones autónomas dentro de Serbia. Kosovo, de este modo, era territorio de la República Federal Yugoslava, conformada en 1945; con Eslovenia, Croacia, Bosnia, Serbia, Montenegro y Macedonia.

Esta constitución propició posiciones enfrentadas entre el nacionalismo albano-kosovar y el nacionalismo serbio. Por un lado, los albano-kosovares creyeron que la constitución determinaba que kosovo tendría un territorio con delimitación diferenciada, es decir, con derechos de autogobierno; aunque Kosovo seguía siendo una provincia y no una república, por lo tanto, sin derecho a la autodeterminación. 
Por otro lado, para los nacionalistas serbios, Kosovo, se estaba rebelando al control y soberanía de Belgrado, porque consideraban a Kosovo como territorio serbio. Consideración que en 1989, lleva al gobierno serbio, mediante una decisión anticonstitucional, a anular la condición autónoma de Kosovo e instalar un régimen militar en ésta provincia.

Al llegar los años 90, se inicia nuevamente un período de desintegración, como consecuencia de la muerte del mariscal Tito (1980) y la caída del comunismo (Recordemos que Yugoslavia hacia 1991-1992 está integrada, solamente, por Serbia y Montenegro).

A partir de 1989, tiene lugar en Kosovo un movimiento albanés de resistencia pacifica en contra de las autoridades serbias que culmina en 1997. Dicho movimiento comenzó a organizar desde la clandestinidad un parlamento, un sistema educativo y un sistema sanitario.

En 1998, como consecuencia del aumento de la represión serbia y del descontento de la mayoría de la población, en especial de la juventud albanesa de kosovo, que a causa del infructuoso resultado de la desobediencia civil, se aumentó el número de los efectivos del Ejército de Liberación de Kosovo (ELK) que creía en la necesidad de la acción violenta para la adquisición de la independencia.

En el primer trimestre de 1998, el ELK profundizó la insurrección contra las autoridades serbias en Kosovo, asesinando a policías, funcionarios y civiles serbios, atacando instalaciones y edificios del gobierno.

Belgrado respondió a la insurrección del ELK con represión militar, dirigida en especial sobre las agrupaciones de las zonas rurales de Kosovo. La represión del gobierno serbio produjo una sucesión de violencias, lo que provocó la intervención de Occidente.

En marzo de 1998, la Secretaría de Estado, estadounidense, insistió en tomar medidas extremas para detener a Belgrado por la represión en Kosovo. Lo que condujo a que Estados Unidos reimplantara sanciones contra Belgrado y que interviniera la OTAN. Dos meses más tarde, el entonces ex Subsecretario de Estado, Richard Holbrooke, fue enviado a los Balcanes para intentar negociar el conflicto de Kosovo.

La diplomacia norteamericana fracasó pues los kosovares albanos pretendían su independencia, Belgrado no estaba dispuesto a renunciar a su soberanía sobre la provincia. La diplomacia norteamericana mostró contradicciones, ya que por un lado, era contraria a la idea de independencia de Kosovo, y por el otro lado, se oponía a la intención de Belgrado de suprimir la insurrección guerrillera dentro de su territorio.

En junio de 1998, la OTAN realizó maniobras aéreas sobre Albania y Macedonia con la intención de disuadir a Belgrado en su política de represión contra los insurgentes en Kosovo. Simultáneamente, los ministros de Defensa de la Alianza Atlántica autorizaron la planificación de bombardeos sobre Yugoslavia y de despliegue de fuerzas terrestres en Kosovo. 
La antigua Yugoslavia

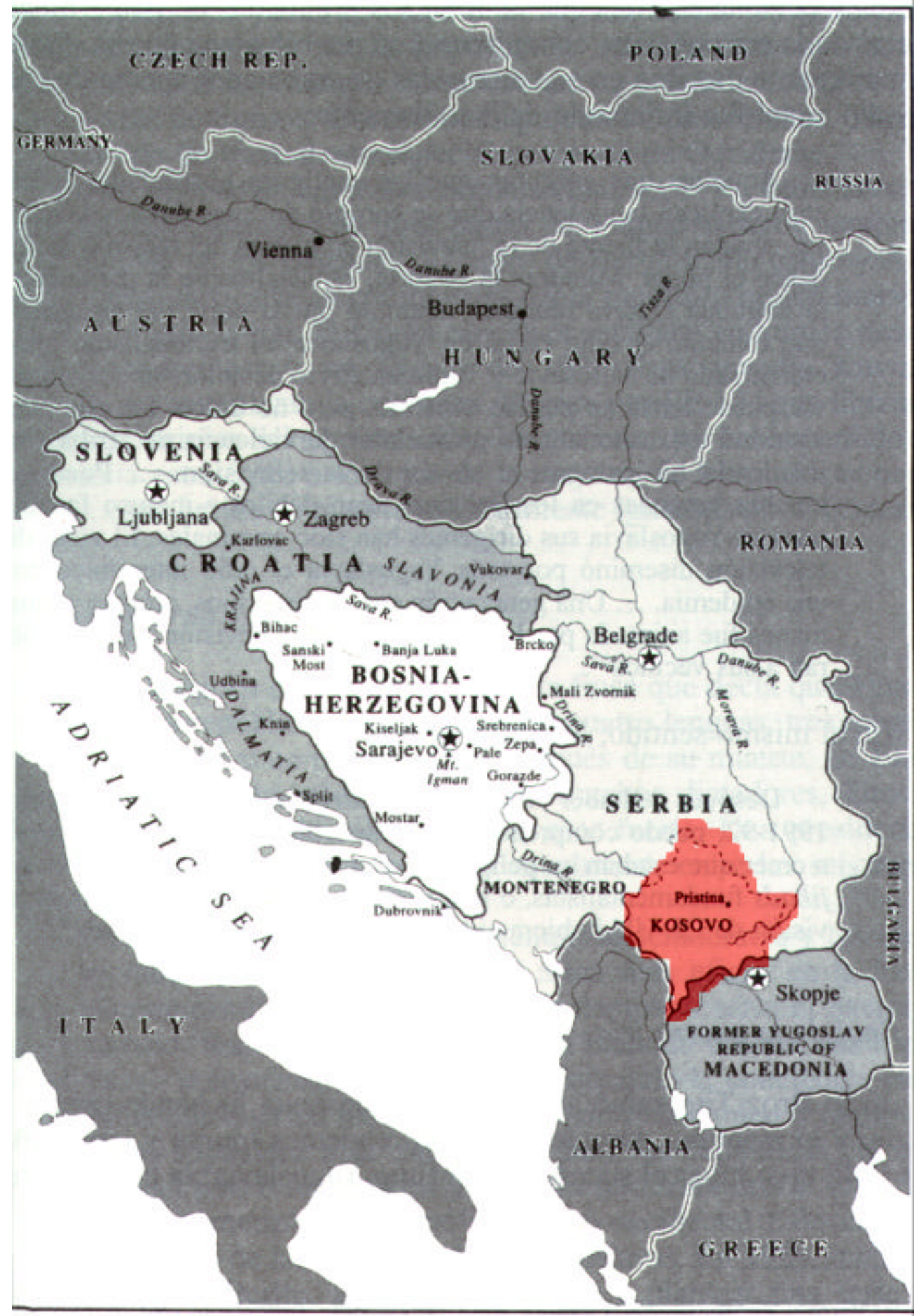

Serbia y Montenegro continúan existiendo dentro de una única estructura federal, que se denomina República Federal de Yugoslavia; las demás repúblicas ex-yugoslavas son todas Estados independientes. Kosovo es una "provincia autónoma» dentro de Serbia 
Fuente: Richard Holbrooke, "Para acabar una Guerra”

La sucesión de ataques del ELK aumentó las operaciones de represión de la guerrilla. En enero de 1999, esas operaciones son anunciadas por la prensa internacional como crímenes de lesa humanidad, por considerarlas acciones de limpieza étnica, llevadas a cabo en contra de los kosovares albanos.

El aumento de las hostilidades alarmó a Estados Unidos y a Europa Occidental, temían que el enfrentamiento condujera a una tragedia, que podía extenderse a Albania y Macedonia, y desestabilizar a los Balcanes. Causa suficiente para motivar las negociaciones de Rambouillet.

Fundamentación de la intervención armada de Estados Unidos y de la Alianza Atlántica (OTAN)

En la guerra de Kosovo la OTAN intervino, sin un mandato expreso del Consejo de Seguridad de la ONU, fuera del límite estipulado en el Tratado de Washington del año 1949 y en una crisis que no representaba una agresión ni un peligro estratégico-militar importante para los países miembros de la Alianza Atlántica.

Estados Unidos fundamentó su intervención en la guerra, con la necesidad de resguardar los valores universales compartidos, con el compromiso de amparar y proteger el cumplimiento del Derecho Internacional Humanitario, así como también, asegurar el efectivo ejercicio de las libertades fundamentales del hombre.

Sin embargo esta justificación fue puesta en duda, por los críticos que manifestaron que la misma carece de solidez, basados en el desgano demostrado por la Casa Blanca y los miembros de la Unión Europea frente a las solicitudes de intervenciones a la acción aliada en Kosovo, para poner fin a violaciones de los Derechos Humanos en Argelia, Sudán, Sierra Leona y Ruanda.

La Secretaría de Estado, de los Estados Unidos, justificó la intervención de la OTAN en el conflicto, diciendo que los Estados miembros de la Alianza deben involucrarse, no solo en crisis con connotaciones estratégico-militar, sino también, cuando estuvieran en peligro los "intereses y valores compartidos".

A partir de estas declaraciones, puede constatarse cómo los valores culturales occidentales comunes confluyen en las relaciones internacionales, y justifican el compromiso efectivo de los integrantes de la OTAN, con un margen potencial de jurisdicción que excede los limites estipulados en su Tratado constitutivo.

\section{Las negociaciones de Rambouillet}

La prioridad, de Estados Unidos y sus aliados de Europa Occidental en las negociaciones de Rambouillet, era alcanzar un acuerdo de paz entre Belgrado y el ELK. Rambouillet estipulaba lo siguiente:

El retiro de fuerzas militares y paramilitares de Yugoslavia en Kosovo.

Restauración de la autonomía política de kosovo.

Un período de transición de tres años, al final del cual en un referéndum se establecería el futuro de Kosovo.

Desarme del Ejército de Liberación de Kosovo (ELK)

Despliegue de fuerzas armadas de la OTAN para mantener la paz en Kosovo.

Después de dieciocho días las negociaciones de Rambouillet llegaron al punto en que tanto Belgrado como el ELK se negaron a firmar. Como consecuencia, las conversaciones se postergaron por diecinueve días más, porque los enviados del ELK regresaron a Kosovo para informar a sus líderes.

La causa de la negación de los representantes del ELK fue que no se garantizaba de forma explícita que Kosovo lograría su independencia al término de los tres años del período de transición. Además la Casa Blanca y los europeos occidentales, se comprometían sólo a 
considerar los resultados del referéndum en la precisión del futuro estado de Kosovo. Como queda establecido en el Capítulo 8, Artículo 1, Sección 3 del acuerdo de Rambouillet. ${ }^{2}$

Al reunirse otra vez las partes, en Rambouillet, después de una fuerte presión ejercida por Estados Unidos, el ELK firmó el acuerdo, pero los serbios se rehusaron a hacerlo, por ello la Alianza Atlántica inició su intervención armada sobre Yugoslavia.

Esta situación nos conduce al punto de partida de la presente investigación que responde al siguiente interrogante:

\section{¿Por qué fracasó la diplomacia en Rambouillet?}

Respuesta que se apoyará en las premisas del realismo estructural, que a su vez servirá de fundamento para demostrar por qué las teorías del Imperialismo Económico, del Realismo Clásico y de la Interdependencia en cascada, resultan insuficientes para explicar la participación y conducta de Estados Unidos.

\footnotetext{
${ }^{2}$ Interim Agreement for Peace and Self-Government in Kosovo (Rambouillet agreement), “Tres años luego de la instrumentación de este Acuerdo, se convocará una convención internacional para determinar el mecanismo del arreglo para Kosovo, en base a la voluntad de la gente, las opiniones de las autoridades relevantes, los esfuerzos de cada lado en relación con la instrumentación de este Acuerdo y el Protocolo Final de Helsinki, llevando a cabo una amplia evaluación de la instrumentación del Acuerdo y para considerar propuestas de cualquier lado en cuanto a medidas adicionales”. Febrero 23, 1999.
} 


\section{Capítulo II Limitaciones de la teoría económica imperialista}

\section{El supuesto económico}

Cuando se inició la guerra en Yugoslavia, la mayoría de los medios de comunicación describieron a Kosovo como una región montañosa con escasos recursos económicos y naturales. De esta forma se fortalecía la versión oficial ante la opinión pública internacional que la Organización del Tratado del Atlántico Norte (OTAN) intervenía por motivaciones exclusivamente humanitaria. ${ }^{3}$

Sin embargo, la región cuenta con el complejo minero Tepca, que posee plomo, zinc, cadmio, oro y plata, considerado como una de las posesiones más importantes de la República Federal Yugoslava. Su valor estimado es de 5.000 millones de dólares, además se calculan sus reservas de carbón en aproximadamente 17.000 millones de tonelada 4 .

La mina de Stari Trg, está rodeada de plantas para el tratamiento de metal, fundiciones, muelles de carga, vías de ferrocarril, de una planta energética y de la fábrica más grande del país en baterías. Estos yacimientos, de plomo y zinc, son los más ricos de Europa.

En opinión de los expertos los depósitos de lignito, de la mina de Stari Trg, podrían abastecernos por los siguientes trece siglos, sus refinerías de plomo y zinc ocupan el tercer lugar en el mundo. Su trascendencia económica no es reciente, ya que uno de los objetivos de la Alemania nacional-socialista en la región, durante la Segunda Guerra Mundial (1939-1945), fue precisamente el dominio de las mismas aspiración que compartían con los británicos.

El New York Times, público el 2 de junio de 1999, un artículo titulado 'El premio: la cuestión del control de las ricas minas de Kosovo", donde planteaba lo siguiente:

"Se ha hecho una serie de repartos no oficiales de Kosovo. Todos los repartos plantean la cuestión de quién controlará la importante región minera norteña. El bombardeo hace difícil encontrar cifras al día de producción. Los expertos dicen que en esa región, existen grandes depósitos carboníferos, además de níquel, plomo, zinc y otros minerales".

La posesión de las minas pertenece al Estado de la República Federal de Yugoslavia. En las tratativas realizadas por el presidente Milosevic con el Fondo Monetario Internacional (FMI), con el propósito de obtener capitales de inversión para la región, una de las condiciones impuestas por el órgano económico fue la privatización de las mismas.

El Estado yugoslavo se opuso a la privatización, ya que las ganancias provenientes de la explotación de las minas eran una de sus fuentes más importantes de recursos. Dentro del círculo político serbio se originó una lucha de intereses entre el presidente S. Milosevic y la oposición.

Milosevic estaba de acuerdo que con una parte de las minas fuera privatizada a una empresa griega, pero la oposición, favorecía la idea de un acuerdo con empresas de capitales norteamericanos y alemanes.

\footnotetext{
${ }^{3}$ El Tratado constitutivo de la OTAN fue realizado en 1949 y en el se establece su carácter de alianza militar con fines defensivos. Incorpora, sin embargo, un conjunto de objetivos adicionales de carácter cooperativo y estructuras necesarias para satisfacer los mismos. Establece asimismo fines y mecanismos de carácter preventivo y incluye objetivos relacionados con la seguridad global en colaboración con sus nuevos socios, en el contexto de los procedimientos de seguridad cooperativa creados a partir de 1992-1993.

Los Estados miembros de la OTAN son: Estados Unidos, Canadá, Gran Bretaña, Islandia, Luxemburgo, Francia, España, Portugal, Noruega, Dinamarca, Alemania, Holanda, Bélgica, Turquía, Grecia, Italia. Los nuevos socios que se incorporaron en 1997 son: Polonia, Hungría y República Checa.

Una de las características de la OTAN es que nunca contó con tropas permanentes. Depende de los medios y los efectivos que dan los países miembros. Uno de los principios fundamentales de la alianza es que el ataque contra uno de los países miembros constituye un ataque contra el conjunto.

${ }^{4}$ The New York Times, 7-99.
} 
La Casa Blanca siempre tuvo especial interés hacia la región de los Balcanes, interés que perduró luego de la caída del comunismo como lo evidencia el informe de la National Security Decisión Directive (NSDD) 133, titulado Política de Estados Unidos hacia Yugoslavia, en el que sé específico la importancia de:

"ampliar los esfuerzos para promover una revolución tranquila que deponga a gobierno y partido comunistas e integren los países de Europa del Este a la economía de mercado"

A partir de esta situación planteada, surgió la creencia de que la intervención norteamericana y la de los principales miembros de la OTAN, respondía a motivaciones económicas, creencia que se fundamenta en los intentos de alcanzar el dominio económico realizados por capitales de origen occidental, para obtener el control de los principales recursos como los complejos mineros de Trepca y Staritrg en posesión del gobierno Serbio.

\section{Intereses económicos; factores determinantes de la intervención de Estados Unidos}

Esta situación nos lleva al siguiente interrogante:

¿El dominio de la riqueza de la región puede ser la causa principal de la intervención de los Estados Unidos y de los principales miembros de la OTAN?

Los que adhieren a la creencia sobre la intervención armada de los Estados Unidos y de las principales potencias que integran la Alianza Atlántica (Gran Bretaña, Francia y Alemania) han visto en el origen de la confrontación causas y fines que los acercan a los enfoques reduccionistas, es decir, que se identifican con la concepción teórica de que la política internacional está condicionada por el comportamiento nacional de los actores internacionales.

La creencia de que la guerra de Kosovo se inició por intereses económicos, no se limitó sólo al enfoque del marxismo sino, también, incluyó a representantes opositores al régimen de la República Popular China (RPCh) como fue el caso de Li Minqui y Wang Chaohua, líderes del movimiento estudiantil de Pekín en marzo de 1989.

La importancia del movimiento estudiantil se evidenció al extenderse a otros sectores de la población, pues produjo una oposición de millones de personas a las medidas políticas de la RPCh, y que culminó con la represión ordenada por el gobierno comunista en la plaza de Tiananmen.

Li Minqui y Wang Chaohua, fueron consultados sobre lo que opinaban a cerca del bombardeo de los Estados Unidos, sobre la embajada China en Belgrado y cada uno respondió:

LI MINQUI:

“...El ataque sobre Yugoslavia es una guerra imperialista sin justificación legal o moral. La "misión humanitaria" de la OTAN ha matado ya a miles de civiles y ha dejado a millones de ellos sin casa y sin trabajo. El bombardeo estadounidense sobre la embajada China fue sólo uno de los crímenes..." 6

WANG CHAOHUA:

“...Creo que el ataque aéreo de la OTAN contra Yugoslavia es ilegal. Es una invasión de un Estado soberano cuyo gobierno, no perfectamente, sino a grandes rasgos, fue elegido democráticamente. Semejante intervención armada en los asuntos de otro país por parte de las grandes potencias supone el resurgimiento de la actitud colonialista bajo nuevas formas. La OTAN justifica sus acciones sobre la base de que hoy la soberanía del "Estado-nación" debe dejar paso a los valores "universales". Mientras tanto, ni un solo país de la OTAN ha renunciado a su propio aparato de seguridad nacional, ni ha compartido su riqueza con los que están sufriendo las consecuencias de las espantosas guerras entre Estados en África o las crisis financieras en Asía..." 7

\footnotetext{
${ }_{6}^{5}$ Jan Oberg, The information warfare about Kosovo, 15-4-99, www.transnational.org.

${ }^{6}$ New Left review (2000). Madrid, $N^{\circ} 1$. Akal, pág. 118.

${ }^{7}$ Ibídem, pág. 119.
} 
Los analistas que comparten esta creencia, se valen como fuente de inspiración de las premisas enunciadas en la Teoría Económica Imperialista (TEI.), desarrollada por John A. Hobson (1858-1940) y por Vladimir Ilich Ulianof Lenin (1870-1924).

\section{Categorías básicas de la Teoría Económica Imperialista (TEI)}

La teoría económica del imperialismo intenta explicar los acontecimientos políticos internacionales más importantes, haciendo mención no solamente al imperialismo, sino también, a los orígenes de la mayoría de las guerras modernas, incluso las circunstancias que permitirían la consolidación de la paz.

Los supuestos básicos de la teoría de Hobson y de Lenin son de carácter económico y no políticos. Hobson estaba convencido de que el imperialismo se gestaba en desbarajustes del sistema capitalista, dado que una minoría tenía posesiones y ahorros en exceso. Mientras que una mayoría carecía del dinero necesario para adquirir bienes de la industria moderna.

Esta situación trae, en los países capitalistas, un dilema representado por el exceso de producción y el bajo consumo. Hobson supone, además que si los capitalistas decidieran realizar una distribución del superávit de la riqueza, fomentarían el bienestar doméstico, lo que, a su vez, evitaría la existencia de problemas estructurales.

Sin embargo, esa minoría propietaria y rica opta por destinar su superávit en reinversiones en el extranjero. Esta situación es la que origina el surgimiento del imperialismo.

“...el empeño de los grandes controladores de la industria por ampliar el canal del flujo de su superávit de riqueza, buscando mercados extranjeros e inversiones extranjeras para ubicar los bienes y el capital que no puedan vender o usar en su país..." ${ }^{8}$

Hobson, también sostenía que el capitalismo financiero manipulaba las otras fuerzas imponiéndoles sentido, por lo que el interés patriótico y la ambición expansionista eran funcionales a los propósitos y fines capitalistas. La causa principal de la guerra internacional, dentro del sistema capitalista, es el desmedido deseo de obtener ganancias.

Estas afirmaciones incluyen la creencia de que las guerras imperialistas benefician a los fabricantes de armas, debido a que las guerras aumentarían las deudas públicas y la inestabilidad en los valores de la Bolsa, un hecho que incrementaría la riqueza de los inescrupulosos financistas. Hobson, argumenta, basándose en James Mill, que el imperialismo era "un vasto sistema de alivio externo para las clases altas".

"No hay guerra, una revolución, un asesinato anarquista, o cualquier otra conmoción pública, que no sea ocasión de ganancia para estos hombres, son harpías que chupan sus ganancias de cada nuevo gasto forzado y toda súbita perturbación del crédito público..."9

Según los supuestos económicos básicos de la TEl de Hobson, el ordenamiento internacional político y económico estaría configurado por una disminuida economía nacional, es decir, con escasos recursos, lo que motivaría a los capitalistas financieros a la busca mayores márgenes de ganancias en el extranjero.

Pero la obtención y dominio de nuevos mercados se materializa en el control de los países menos desarrollados, quienes son víctimas fáciles por necesitar capitales, para cubrir esa falencia, se ven forzados a otorgar elevadas tasas de interés para motivar el crédito extranjero.

Estos financistas especuladores, aseguran el retorno de sus ganancias en los intereses que deben pagar los Estados deudores, este pago se relaciona con los sectores políticos que hacen que el interés nacional se confunda con el interés sectorial, comprometiendo la política exterior de los países, situación que desencadena la competencia entre los países desarrollados por el dominio de los mercados periféricos.

Lenin se baso, para la elaboración de su Teoría del Imperialismo, en los presupuestos de la teoría de Hobson y de Hilferding. Lenin consideraba:

“El imperialismo es el capitalismo en estado de desarrollo en el cual el dominio de los monopolios y el capital ha adquirido una pronunciada importancia, en el cual la invasión de todos los territorios del globo entre las grandes potencias capitalistas se ha completado..."10

\footnotetext{
${ }^{8}$ Hobson J.A. (1965). “Imperialism A Study.” University of Michigan Pres. Pág. 85

${ }^{9}$ Ibídem. Pág. 58
} 
Según esta teoría el capitalismo monopólico o imperialismo, está caracterizado pr la centralización de la producción en asociaciones (cárteles, sindicatos, truts, etc.), y por una desenfrenada competencia por la obtención de materias primas. De ello resultaría la consolidación de las oligarquías financieras y la materialización de la expansión colonial. Además de la dominación y explotación de los países débiles por parte de las potencias capitalistas.

Las diferencias entre Hobson y Lenin residen, esencialmente, en que el primer teórico creía que el imperialismo podía ser evitado si los capitalistas dieran lugar a una redistribución de la riqueza de manera más equitativa, a través de políticas gubernamentales adecuadas. Por el contrario, Lenin, estaba convencido de que la redistribución de la riqueza no tendría lugar y ello se debía a la propia idiosincrasia de la dirigencia política capitalista. Por consiguiente el imperialismo era ineludible y formaba parte de la política de los Estados capitalistas en su etapa desarrollada.

\section{El realismo estructural y su crítica a la explicación de la TEI sobre la guerra}

Según la TEI, lo que determina que un Estado sea poderoso o débil es su capacidad económica. Para ella, el poder económico sería esencial para establecer el margen de libertad política de un actor internacional.

En cambio, el realismo estructural, considera que la capacidad económica no puede separarse de las otras capacidades de los Estados, para él, los Estados combinan los medios económicos para la obtención de metas políticas y militares, y disponen, medios militares y políticos para el logro de fines económicos.

Sin embargo el neorrealismo sostiene que, en vez de analizar las capacidades, deben comprenderse las relaciones de los Estados y que al ser estas relaciones multilaterales, el mundo es necesariamente multipolar.

El actual proceso de gestación del orden internacional presenta características de un sistema multipolar que facilita la dispersión del poder y la disminución de los problemas a los que pueda aplicarse, de manera única, el uso de la fuerza. Como resultado de este proceso de dispersión de poder, existe una única superpotencia militar hegemónica, la de Estados Unidos, con una multipolaridad económica, cultural y política.

Desde la visión TEl se cree que si una nación es poderosa económicamente también lo será en el aspecto militar. Esta premisa resulta insuficiente, ya que en el actual contexto internacional los mayores competidores, en el aspecto económico, de los Estados Unidos, son Alemania y Japón, países que desde el punto de vista militar no son considerados súper potencias.

En el caso de Estados Unidos sus recursos y capacidades, con respecto al eje de poder estratégico-militar, resultan preponderantes incluso en el marco de la OTAN. Su principal ventaja estratégico-militar se concentra en la rapidez del despliegue de sus fuerzas, en su tecnología y en la superioridad de medios para la recolección e interpretación de información.

Según el pensamiento de la TEl los atributos económicos y militares de Estados Unidos, serían suficientes para que emprendiera de manera autónoma sus intervenciones armadas sin otra justificación que el cumplimiento de sus objetivos económicos, sin considerar las opiniones de los otros actores internacionales involucrados.

Sin embargo, la actuación norteamericana en el "orden internacional" y en especial en el conflicto de Kosovo, despertó sospechas y suspicacias en el resto de los actores internacionales, a causa de su preeminencia en medios y recursos. Esto motivó que el gobierno norteamericano, enfrentara serios cuestionamientos, domésticos e internacionales, a sus acciones en política exterior.

Situación evidenciada en la preocupación de la Casa Blanca por obtener una legitimación internacional a la intervención de sus fuerzas militares en el conflicto.

\footnotetext{
${ }^{10}$ Lenin V. I. "Imperialism: The Highest Stage of Capitalism”. New York. International Publishers, 1939. Pág. 84
} 
Este clima de sospechas y suspicacias con respecto a la actuación norteamericana, se manifestó no sólo en el ámbito internacional, sino también entre los miembros de la Alianza Atlántica, puesto que lejos de conseguir un apoyo unánime a las acciones militares en territorio serbio, surgieron posturas reacias a la intervención armada en el contexto mundial.

Las actitudes de recelo y desconfianza se evidenciaron en el comportamiento de varios países, entre ellos Italia, ya que su primer ministro Massimo d' Alema (simpatizante de izquierda) durante la guerra actuó dubitativamente. Pues por un lado, estaba obligado a cumplir con las obligaciones de la Alianza Atlántica, como el primer Ministro italiano, y por otro lado, tenía que enfrentar la oposición interna causada por la participación de las fuerzas armadas italianas en la guerra. Esta circunstancia, contribuyó a que Italia fuera considerada por los Estados Unidos como un aliado poco fiable. El primer ministro d' Alema insistía en la necesidad de terminar con las acciones bélicas en Kosovo y volver a las negociaciones diplomáticas con Belgrado.

Grecia también demostró su disconformidad con el ataque de la OTAN, ya que siempre tuvo buenas relaciones con Serbia, a causa de sus continuos conflictos con los turcos. Los kosovares representan la presencia turca en la región de los Balcanes.

La oposición griega a los ataques a Serbia fue tan fuerte que el primer ministro, Costas Simitis, tuvo que suavizarlas para recomponer su relación con el resto de los miembros de la Alianza Atlántica.

En relación con los recién ingresados socios a la OTAN: República Checa, Hungría y Polonia, sus motivaciones de pertenencia estaban muy influenciadas por las ventajas que les daba el pertenecer a la Unión Europea.

Los checos reaccionaron de manera indecisa a causa de los lazos históricos que los unen a los yugoslavos, pues los habían apoyado en 1938, cuando se firmo el pacto de Munich y también en la Primavera de Praga cuando fueron reprimidos por las fuerzas soviéticas.

Hungría también titubeó, porque posee una frontera directa con Serbia y además tiene problemas étnicos entre su población. Sin embargo, Polonia estuvo decididamente a favor de las operaciones de la OTAN, en especial por su buena relación con Estados Unidos.

Otro actor internacional que se mostró dubitativo en dar su apoyo a la acción de la OTAN, pese a las supuestas motivaciones humanitarias esgrimida por Estados Unidos, fue el Vaticano; quien reclamaba de manera persistente el fin de los ataques aliados en Yugoslavia. A tal punto que, a través del monseñor Tauran, el Papa hizo llegar una carta a Milosevic, para hablarle sobre la obligación de respetar los derechos y la vida de los kosovares.

Todo este contexto complicó la supuesta actuación hegemónica de Estados Unidos, de manera unilateral y motivada exclusivamente por cuestiones económicas. Lo que evidencia, y que no lo tiene en cuenta la TEI, es que previamente o simultáneamente a sus acciones, la Casa Blanca, debe elaborar un discurso legitimador que permita lograr el consenso internacional a sus acciones en política exterior.

Esta situación pone de manifiesto la importancia de las relaciones entre las unidades ínteractuantes y las relaciones de éstas con la estructura internacional. Evidenciándose en ello los conceptos esenciales del realismo estructural.

La TEl considera que la competencia entre las potencias capitalistas provoca una desestabilización del "orden internacional", y que esa desestabilización es producto de la ambición de ciertos Estados para aumentar su poder. Lo que generaría fricciones entre los actores internacionales.

Ahora bien hay que tomar nota que en la guerra de Kosovo no sólo se dio una alianza entre los países desarrollados, sino que también formaron parte de la misma países emergentes y que pertenecían a distintas culturas y creencias religiosas.

Otro aspecto importante a tener en cuenta, en este análisis del conflicto, es que el mismo fue originado por un Estado no capitalista y por causas que tienen sus raíces en cuestiones religiosas, étnicas, políticas y culturales, además, claro está, de la económica. Aspectos a los que la TEl no les asigna la debida importancia. ( Anexo 2)

La insuficiencia de la explicación basada en la TEI también se evidencia cuando se tiene en cuenta el destino de las principales inversiones de capital norteamericano, dirigidas mayoritariamente a países desarrollados. Situación que no concuerda con el comportamiento esperado de un Estado imperialista. 
La TEI sostiene que una mayor igualdad entre las naciones daría a cada una de ellas la posibilidad de defenderse, y que esto a su vez transformaría al "orden internacional" en más predecible y seguro.

Por el contrario, el neorrealismo cree que pese a las injusticias de la desigualdad entre las naciones no deben obviarse sus virtudes y a diferencia de la TEI, que presupone que un mundo de muchos Estados iguales en sus poderes sería más pacífico, el realismo estructural, considera que la desigualdad entre los Estados, aunque no es garantía absoluta, favorece la paz y la estabilidad.

Las diferencias entre los actores polares y las potencias menores, sumadas a otras circunstancias internas del acontecer nacional (políticas, económicas y sociales) fueron las responsables de que tanto Rusia y China, no dieran un decidido apoyo a Serbia. La causa que pesaron en la actuación de ambos países; para no adoptar una férrea postura de rechazo a la intervención armada de la Alianza, fue la probable escalada y extensión de la guerra.

La teoría neorrealista, a diferencia de la TEI, cree que la característica económica de los Estados no es suficiente para que se la considere como variable determinante, de la política exterior de una nación.

Como, las economías capitalistas poseen un amplio espectro de elecciones y medios efectivos para manejarse internacionalmente, el realismo estructural afirma, que establecer de que, manera actuarán los Estados no puede ser dilucidado por medio del estudio de la característica económica interna exclusivamente.

Al recordar el contexto doméstico de la economía norteamericana, anterior a la crisis en Kosovo, se constató que se hacía hincapié en la necesidad de lograr una recuperación y revitalización económica con la finalidad de devolverle, a Estados Unidos, la capacidad de liderazgo internacional.

El entonces presidente de los Estados Unidos, William Jefferson Clinton, se mostró predispuesto a priorizar los problemas domésticos frente a las amenazas que se planteaban en política exterior. Su actitud se basó en la experiencia del antes presidente George Bush, a quien la opinión pública, en su mayoría, lo hacia responsable del estancamiento y de la disminución del poder adquisitivo por priorizar los asuntos mundiales ante los problemas de la política doméstica.

Para evitar las críticas de las que había sido objeto el anterior presidente Bush, el presidente Clinton adoptó una política que consistía en instrumentar un plan de compensaciones fiscales a las empresas que invirtieran y fomentaran el empleo, promoviendo la competitividad, el ahorro y la inversión interna.

La meta de la Administración Clinton era, de reducir el déficit en 145.000 millones de dólares en un período de cuatro años, lo que necesariamente demandaba reducciones drásticas en todos y cada uno de los sectores de Seguridad Social y en el presupuesto de la Defensa Nacional. Este último aspecto, en especial, no es compatible con un país imperialista considerando el pensamiento de la TEl.

Conforme a los enunciados de la TEl, la intervención de los Estados Unidos en la guerra, tendría que haber sido contundente. Asumiendo, sin inhibiciones, los costos de una posible escalada militar. Sin embargo, la Casa Blanca se mostró, durante el conflicto, cautelosa y hasta dubitativa en ciertas ocasiones, especialmente cuando se trataba el tema del empleo de fuerzas terrestres en la guerra.

Se ve de este modo, entonces, que en la guerra de Kosovo la actuación militarista y autónoma de uno de los miembros de la Alianza Atlántica, como Estados Unidos, no se materializó porque las características de la estructura internacional limitaron su política exterior. Así como también, los límites de la organización de la estructura política interna, le restringió la capacidad de autonomía a los políticos de la Casa Blanca, en los cuales pesaba, y mucho, los cambios en la opinión pública con relación al manejo del conflicto.

Tal fue la importancia de la opinión pública para los funcionarios de la Administración Clinton, que llegó a frenar la iniciación de la invasión terrestre a Kosovo, aunque esta actitud no se corresponde con la estrategia de un país imperialista.

$\mathrm{Si}$ el factor económico hubiera sido el factor determinante de la intervención norteamericana en la guerra, no hubiese habido la indecisión, y tardanzas en los estrategas de la Casa Blanca. Esta actitud le fue reprochada por Gran Bretaña, uno de sus principales aliados 
dentro y fuera de la OTAN, pues le pedía de manera insistente que la invasión terrestre fuera llevada a cabo sin más demoras.

La indecisión del gobierno estadounidense, tiene una posible explicación al reflexionar que la guerra entraña lo irracional y lo imprevisible. Circunstancia que es contraria con el modelo capitalista, que prefiere un escenario predecible y pacífico en consideración a la disminución de los costos.

También es importante destacar que, durante el conflicto, no se produjo el desarrollo del ánimo jingoísta ${ }^{11}$, como sí estuvo presente durante la guerra del Golfo en 1991.

Con respecto a los neo marxistas podrían llegar a justificar la vigencia de la TEl, a través de la Teoría del Neocolonialismo, para dar respuesta al interrogante de ¿cómo es posible convalidar la TEI con la realidad, cuando los Estados capitalistas no siguen políticas coloniales y ninguno ejerce un dominio colonial?

Magdoff $\mathrm{H}$., uno de los principales teóricos del neo marxismo, considera en su tesis sobre el neocolonialismo, que la política internacional está determinada por cuestiones económicas.

Este autor, afirma que la política internacional tiene su fundamento en la política de los Estados capitalistas y que, dentro de estos Estados, los instrumentos económicos privados se desarrollan de tal forma que aún su aplicación informal es suficiente para controlar y explotar efectivamente los recursos de otros países ${ }^{12}$.

Las corporaciones multinacionales tienen tal magnitud, que sus operaciones e influencias variadas, les permitía tener la capacidad de desarrollar poder, y controlar a países débiles económicamente.

La expansión comercial es enorme y su capacidad de preservación es tan sólida que las empresas construyen sus imperios "invisibles", sin el respaldo de políticas gubernamentales o de las fuerzas nacionales.

En la guerra de Kosovo, si la expansión comercial hubiere sido la motivación principal, no hubiese contado, necesariamente, con el apoyo de los gobiernos nacionales. Estados Unidos, junto a los restantes socios de la OTAN, llevaron a cabo, cerca de 35,000 bombardeos que destruyeron gran parte de la infraestructura social e industrial de Yugoslavia.

La OTAN considera que destruyó el 57 \% (por ciento) de las reservas petroleras de Serbia y casi todos los caminos, ferrocarriles y puentes; además de haber logrado la casi paralización de las plantas generadoras de energía, y la destrucción de redes de agua potable de las principales ciudades. El destrozo también llegó a la infraestructura hospitalaria, educativa y laboral.

Sin embargo, el éxito obtenido por los Estados Unidos no mejoró su imagen ante sus socios de la OTAN, ni ante la comunidad internacional. Globalmente, cuando cayó el comunismo soviético el prestigio norteamericano ascendió, porque se pensaba que este país haría posible la instauración de un orden internacional fundado en los valores democráticos de igualdad y respeto a los derechos humanos.

Estados Unidos fue visto con temor y desconfianza por su poder, el cuál no dudó en utilizar para proteger sus intereses, como por ejemplo, su necesidad de permanecer en suelo europeo y de asegurar la vigencia de la OTAN, para ejercer su influencia en el territorio y facilitar así la gobernabilidad en una región tan sensible. Esta percepción se evidenció en el comportamiento del gobierno de China, y de los quince miembros de la OTAN, que el mismo

\footnotetext{
${ }^{11}$ J. A. Hobson: Imperialism: A Study (Ann Arbor, University of Michigan Press, 1965), p. 215. Afirma : "El jingoísmo es simplemente la lujuria del espectador, no justificado por ningún esfuerzo personal, riesgo o sacrificio, que disfruta de los peligros, dolores y matanza de semejantes a quienes no conoce, pero cuya destrucción desea en una ciega y artificialmente estimulada pasión de odio y venganza... La ardua y cansadora monotonía de la marcha, los largos períodos de espera, las duras privaciones, el terrible tedio de una campaña prolongada no juegan papel alguno en su imaginación; los factores redentores de la guerra, el puro sentimiento de camaradería que despierta el peligro personal frecuente, los frutos de la disciplina y la autolimitación, el respeto por la personalidad de los enemigos cuyo coraje se debe reconocer y a los que llega a considerar como semejantes, todos esos elementos moderadores en la guerra real son eliminados de la pasión del "jingo".

${ }^{12}$ The Age of Imperialism, Cap. I y V. New York: Monthly Review Press. 1969
} 
día en que obtenían su triunfo sobre Yugoslavia, anunciaban que convertirían a la Unión Europea en una potencia militar autónoma. Igual preocupación se dio en los políticos norteamericanos que ya avizoraban el coste político internacional.

El ex secretario del Estado norteamericano, Lawrence Eagleburger, declaró en el programa periodístico Nightline, de la cadena de televisión $A B C$, luego de la rendición de Serbia:

“Proyectamos sobre el mundo la imagen del patrón de la vereda que con sólo empujar un botón mata a gente. No nos cuesta nada más que el precio del misil... esa imagen nos perseguirá cuando tratemos de negociar con el resto del mundo."

Otra falencia que tiene la TEl, y también el Neocolonialismo, consiste en la imposibilidad de explicar el tipo de imperialismo ${ }^{13}$ generado por las potencias no capitalistas; como es el caso de la ex Unión Soviética, y por qué no, también la falta de explicación sobre el intento de Milosevic de imponer la idea de la "Gran Serbia" al resto de las repúblicas que integraban la ex Yugoslavia.

La TEI, al priorizar los intereses económicos de los países capitalistas como determinantes de su política exterior, desconoce o resta importancia a otros factores, como lo son las cuestiones étnicas, religiosas, culturales y las de seguridad, cuya trascendencia se dan en un mismo nivel.

En la guerra de Kosovo los intereses nacionales de los Estados Unidos y de los restantes miembros de la Alianza se complementaron con los principios amparados por el lus Cogens. Es por ello, que la Casa Blanca se manifestó a favor del Derecho de Injerencia, en situaciones relacionadas con la depuración étnica, violaciones a los Derechos Humanos Universales, existencia de campos de concentración y asesinatos en masa.

Sin embargo, es preciso destacar que, cuando los intereses vitales de una gran potencia no están en juego, la materialización del compromiso de las potencias polares con la defensa de los Derechos Universales del Hombre, no es contundente ni inmediato.

De todas maneras es preciso puntualizar que en la región de los Balcanes la inacción de las potencias polares, hubiera agravado la guerra, pues esta se hubiera extendido a los países limítrofes. El agravamiento no hubiera respondido solamente a cuestiones económicas, sino que también hubiese obedecido a problemáticas relacionadas a reivindicaciones nacionales y étnicas. A las que son sensibles los países como Macedonia, Hungría, Rumania, Bulgaria, Ucrania y la región del Cáucaso.-

\footnotetext{
${ }^{13}$ Michael W. Doyle: Empires (Ithaca, N.Y., Cornell University Press, 1986), p. 40. El autor señala que lo que caracteriza al imperio es el control tanto de la política exterior como interna. Donde sólo la política exterior se controla, utiliza el término hegemonía.
} 


\section{Capítulo III Insuficiencia del realismo clásico}

\section{Consideraciones y postulados básicos del realismo}

La teoría realista considera que los Estados son actores unitarios que tienen un doble objetivo: el primero obedece a su propia preservación, el segundo, alcanzar el dominio universal.

En la guerra de Kosovo no estaba en juego la propia seguridad de los Estados Unidos ni su supervivencia, así como tampoco su posición de líder internacional.

Estados Unidos se negó a ejercer un dominio universal a pesar de que poseyera la exclusividad nuclear; si bien en una primera etapa de la guerra fría, asumió el compromiso de liderar, aunque con reticencias, la lucha contra el avance del comunismo.

Sin embargo, desde el punto de vista geopolítico, el realista Henry Kissinger dice que:

“...los Estados Unidos son una isla frente a las costas de la gran masa continental de Eurasia, cuyos recursos y población son muy superiores a los suyos. La dominación de cualquiera de las dos principales esferas de Eurasia - Europa o Asia- por una sola potencia sigue siendo una buena definición del peligro estratégico para los Estados Unidos, con Guerra Fría o sin ella". ${ }^{14}$

Pues, desde el punto de vista de la teoría realista, la política interna puede separarse claramente de la política externa, ya que la amenaza de violencia y el uso recurrente de la fuerza es lo que diferencia las cuestiones internacionales de las nacionales.

El neorrealismo, en cambio, considera que el uso de la fuerza o el constante temor de que sea usada, para asegurar la supervivencia o conservación de un Estado, no son suficientes para diferenciar los asuntos internos de los externos. Kenneth Waltz dice al respecto:

“... Si el uso posible y real de la fuerza caracteriza tanto al orden nacional como al internacional, no puede establecerse, entonces, ninguna distinción de la fuerza. Ningún orden humano es una garantía de no-violencia..."

En concordancia con el pensamiento de Kenneth Waltz, el origen de la guerra en Kosovo, constituyó un conflicto de orden interno cuya intensidad involucró a la población civil e implicó violaciones masivas de los derechos humanos. En efecto, esto permite apreciar cómo la línea de lo que separa el ámbito de la política nacional y la política exterior, se desdibuja.

\section{Hacia la legitimación de las intervenciones internacionales}

Las últimas intervenciones de la comunidad internacional se efectuaron por medio de Resoluciones del Consejo de Seguridad, en Yugoslavia, por medio de la Resolución 770-1992, y en Haití, se llevo a cabo en contra del gobierno autoritario que no respetaba la vigencia de los derechos humanos y los valores democráticos ( 1993-1994). La comunidad internacional hace hincapié sobre conflictos de orden interno, que por su intensidad excederían el ámbito nacional lo que confirma la tendencia a una confusa delimitación de la política interior y exterior.

En consecuencia, como ocurrió en Kosovo, la comunidad internacional tuvo que reformular los tópicos que pertenecen históricamente al orden interno, de los que comienzan a ser considerados de responsabilidad internacional.

En este contexto el Consejo de Seguridad por medio de la Resolución 1244 (1999), pone término a la intervención de la OTAN avalando las afirmaciones precedentes, ya que pueden

\footnotetext{
${ }^{14}$ Kissinger Henry (1995). "LA DIPLOMACIA”. México. Fondo de Cultura Económica. Pág. 810

${ }^{15}$ Waltz Kenneth N (1988). “TEORÍA DE LA_POLÍTICA INTERNACIONAL”. Argentina. Gel. Pág. 153.
} 
apreciarse los signos de una eventual reformulación de las relaciones del sistema internacional y la estructura internacional ${ }^{16}$.

En consideración al inciso 4 del Anexo II de la Resolución antes mencionada y que transcribo, se evidencia una reformulación de las relaciones entre la comunidad internacional y las Naciones Unidas:

“...La fuerza de seguridad internacional contará con una presencia sustancial de la Organización del Tratado del Atlántico Norte, que deberá ser desplazada bajo su comando y control unificados y se le ordena y autoriza a establecer un ambiente de salvaguardia para todo el pueblo de Kosovo y facilitar el retorno a salvo a sus hogares de todas las personas desplazadas y refugiadas..." 17

Estados Unidos, al igual que los miembros de la Unión Europea, estaba en desacuerdo en favorecer o incentivar reivindicaciones nacionales, que pudieran romper el delicado equilibrio logrado en los Balcanes. Además, Serbia no rivalizaba ni tampoco aspiraba a competir con la OTAN, porque su meta era consolidar su integridad territorial.

En febrero de 1998, se rompe el equilibrio en la región, por causa del líder serbio Milosevic, quien autoriza a las fuerzas policiales y militares serbias para que lleven a cabo una limpieza étnica en la provincia de Kosovo.

Esta acción generó una crisis humanitaria dado que los Derechos Universales del Hombre y el ejercicio de las libertades fundamentales, defendidas y reconocidas en la Carta de las Naciones Unidas, fueron violadas. Los Estados Unidos y los miembros de la Unión Europea, reaccionaron ante los hechos de violencia.

Teniendo presente los postulados realistas, Estados Unidos y la Unión Europea, debieron intervenir de manera decidida y contundente para restablecer el status quo en la región. La intervención armada a ejecutar se hubiera realizado sin escatimar medios, teniendo en cuenta que el poder de la alianza maximizadora, que constituye la OTAN, era muy superior al poder defensivo y económico de Serbia. Sin embargo, Estados Unidos y los miembros de la OTAN, necesitaron una legitimación internacional. Estados Unidos tuvo que fundamentar y procurar un consenso, ante la mayoría de su población, así como también ante los miembros de la OTAN, Ias Naciones Unidas y la opinión mundial.

El comportamiento obedecía a las características del sistema internacional y a la interacción de éste con la estructura internacional, conceptos, formulados por el realismo estructural y que están en relación con los elementos que, a su juicio, distingue la política nacional de la internacional.

La distinción de dichos ámbitos, nacional e internacional, dentro de la política, no se basa en el uso de la fuerza sino en la diferencia de estructuras.

Siguiendo las premisas enunciados por Kenneth Waltz, la separación de la política nacional e internacional no radica en el uso de la fuerza sino en los diferentes modos de organización destinados a hacer lo que sea necesario al respecto. En palabras de Waltz:

“...Un gobierno, gobernado por medio de algún standard de legitimidad, se arroga el derecho de usar la fuerza es decir, de aplicar una variedad de sanciones para controlar el uso

\footnotetext{
${ }^{16}$ Waltz Kenneth . Op. cit. pp.119-121. “... Un sistema está compuesto por una estructura y por unidades interactuantes. La estructura es el componente sistémico que hace posible pensar en el sistema como un todo... es hallar una definición de estructura que no incluya los atributos y las interacciones de las unidades. Las definiciones de estructura deben dejar de lado, o abstraer, las características de las unidades, su conducta y sus interacciones. De esto se desprenden tres proposiciones. Primero, que las estructuras pueden persistir mientras la personalidad, la conducta y las interacciones sufren grandes variaciones. La estructura se diferencia agudamente de las acciones y las interacciones. Segundo, una definición estructural se aplica a dominios de sustancias muy diferentes en tanto y cuanto tengan disposiciones semejantes de las partes (Cf. Nadel, pp.104-109) Tercero, como esto último ocurre, las teorías desarrolladas para un dominio particular pueden aplicarse, con algunas modificaciones, también a otros dominios. Una estructura se define por medio de la disposición de sus partes. Sólo los cambios de disposición son cambios estructurales. Un sistema está compuesto por una estructura y por las partes interactuantes. Tanto las estructuras como las partes son conceptos, relacionados con, pero no idénticos a, los agentes y las agencias reales..."

${ }^{17}$ Resolución 1244(1999). CONSEJO DE SEGURIDAD DE LAS NACIONES UNIDAS.
} 
de la fuerza de sus súbditos. Si algunos usan fuerza privada, otros pueden recurrir al gobierno. Un gobierno no tiene el monopolio del uso de la fuerza, como resulta evidente..." 18

Es decir que en un Estado-nación, las autoridades formalmente elegidas, poseen el monopolio legítimo del uso de la fuerza. Ello implica que los ciudadanos no están obligados a ejercer por cuenta propia su defensa, ya que las autoridades públicas se responsabilizan de eso.

No obstante, en un sistema internacional, un Estado, por más poder que posea, no cuenta automáticamente con la legitimidad para el ejercicio de la fuerza.

Esta circunstancia explica por qué Estados Unidos a pesar de ser una gran potencia militar, necesita la legitimación internacional de sus intervenciones armadas. Esto es así porque el sistema internacional es de auto-ayuda, por lo tanto se debe tener especial consideración a la interrelación del sistema internacional con la estructura internacional; como quedó demostrado en la guerra de Kosovo.

Los que critican la intervención armada de la OTAN en Kosovo, entre ellos Robin Blackburn, sostienen que la misma fue realizada para establecer un protectorado en Kosovo, sin tomar en cuenta las pérdidas y el sufrimiento de la población, y de manera premeditada ha acumulado problemas para el futuro.

Blackburn, considera que la guerra aérea no fue un error por que existiera otra opción militar, sino que, desde un principio, se pudo haber arribado a un acuerdo para que se retiraran las fuerzas serbias y que las fuerzas de la ONU las sustituyeran.

Este autor, cree, además, que las negociaciones fracasaron porque no permitieron a la OTAN establecer el protectorado que ansiaba. El gobierno yugoslavo estaba presionado, a firmar el acuerdo de Rambouillet, pero se negaba a aceptar las disposiciones militares que en el se estipulaban.

Estas disposiciones militares, rechazadas tanto por Serbia como por Moscú, decían que la fuerza internacional de seguridad, encabezada por la OTAN, tendría el derecho de inspeccionar en la totalidad de la república yugoslava y, además, que sus integrantes estarían exentos de la jurisdicción de la justicia local por sus acciones.

Para Estados Unidos, Europa, constituye un aliado natural, ya que en términos generales comparten el mismo origen étnico y los mismos valores: religiosos y políticos. Así mismo el continente europeo, es vital para la propagación de la democracia mundial. Pero ante todo, como fundamenta Zbigniew Brzezinski:

“...Europa es la principal cabeza de puente geopolítica en el continente euroasiático. Los intereses estadounidenses en Europa son enormes. A diferencia de los vínculos de los Estados Unidos con Japón, la Alianzas Atlántica conduce la influencia política y el poder militar estadounidense directamente al continente euroasiático..."19

La debilidad política y militar de Europa fue puesta de manifiesto por su incapacidad para resolver la crisis de Bosnia y la guerra de Kosovo, dos aprietos que facilitaron la intervención armada de la OTAN y de Estados Unidos en la región.

La participación de Estados Unidos en los conflictos también era una necesidad europea. Asimismo, si los decisores políticos norteamericanos se hubiesen guiado por las premisas realistas, tendrían que haber asumido sin titubeos los costos necesarios para terminar con la amenaza de la actuación de las fuerzas serbias.

Por consiguiente, es posible establecer cómo una de las premisas más importantes de la teoría realista no puede aplicarse en la guerra de Kosovo, pues, si hubo un acuerdo previo entre las principales potencias integrantes de la OTAN, para el establecimiento de un protectorado aliado en Kosovo, es que sí existió una armonía de intereses geopolíticos y estratégicos, al menos, entre los principales miembros de la OTAN; EE.UU., Gran Bretaña, Francia y Alemania.

\footnotetext{
${ }^{18}$ Waltz K. Op. cit. Pág. 153

${ }^{19}$ Blackburn Robin. (2000) “KOSOVO LA GUERRA DE EXPANSIÓN DE LA OTAN”. Revista New Lef .Madrid. Akal. Pág. 135
} 
Esta situación significa, en cierta medida, una coincidencia de intereses geoestratégicos entre Estados Unidos y sus aliados de Europa Occidental, ya que una extensión de la influencia europea hacia el este, hubiera involucrado, también, una extensión de la influencia norteamericana en coincidencia con sus intereses vitales.

\section{Estados Unidos y la necesidad de legitimar intervenciones internacionales}

Estados Unidos necesitó legitimar sus intervenciones internacionales después de la Guerra Fría, tal como se evidenció en el conflicto de Kosovo. Esta circunstancia confirma una de las premisas del realismo estructural que describe al sistema internacional como un sistema de auto-ayuda. Por tal motivo, Estados Unidos debió enfrentar, de modo ascendente, cuestionamientos a su acción en relación con la falta de legitimación internacional.

La India, que constituye la democracia más grande del mundo, consideró la intervención de Norteamérica y de la OTAN como una diplomacia de cañoneras. Israel, principal aliado norteamericano en Medio Oriente, condenó de forma muy áspera al papel de la OTAN. Egipto, otro aliado importante de Estados Unidos, efectuó una fuerte condena a través del diario oficial: Al Ahram..

La Administración Clinton antes, durante y después, del inicio de las acciones militares tomó en cuenta al sistema internacional y, en especial a la estructura internacional, pues la superioridad de medios y recursos, de Estados Unidos, despierta sospecha y temor en el resto de los actores internacionales, inclusive entre sus aliados principales.

Esa situación es contemplada por la teoría neorrealista y, en contraste, no por la realista, dado que la mutua interrelación entre los actores, que afecta tanto a los Estados, como a sus atributos en relación con la incidencia de la estructura internacional sobre las unidades ínteractuantes es un concepto esencial en el realismo estructural.

La guerra de Bosnia, había culminado con la aceptación del acuerdo de Dayton (1995), pero en el mismo no se incluyó el tema de Kosovo, a causa de la intransigencia del presidente Milosevic. Situación que fuera tolerada por Washington y los europeos, pues aquel tenía una participación funcional a sus intereses geopolíticos.

La situación planteada, sin embargo, permitía consolidar la viabilidad del acuerdo de paz para Bosnia a la vez que permitía suponer que se lograría la pacificación y la estabilización de la convulsionada región de los Balcanes. Pero el presidente Milosevic, interpretó esto como una señal de no-injerencia en los asuntos internos de Serbia. La percepción del líder serbio respecto a la conducta de Occidente, lo convenció de la viabilidad de su proyecto de construcción de la "Gran Serbia" y de sus planes con respecto a la provincia de Kosovo. Haciendo resurgir, paralelamente, un profundo nacionalismo serbio.

El comportamiento de los actores internacionales involucrados en la crisis, responde a los postulados realistas, debido a que la situación anteriormente descripta, muestra cómo los actores internacionales antepusieron sus intereses nacionales a los principios Universales del Hombre, es decir el de la autodeterminación de los pueblos contenido en la Carta de las Naciones Unidas; artículo 2.

Este nuevo contexto internacional indicaba una revitalización del concepto de la "raison d" état y del equilibrio de poder", concepto gestado por Armad Jean du Plessis, cardenal de Richeleu, quien fuera ministro de Francia (1624 a 1642)

La meta del Cardenal Richelieu, era impedir que los intentos de gobierno universal de los Habsburgo se concretaran y, lograr, a la vez, una hegemonía francesa en Europa. Del fracaso de sus intentos se gestó un equilibrio de poder.

La trascendencia para Francia en la reformulación de su política exterior, fue que la raison d'état, desplazó al concepto dominante por entonces en política exterior de los valores universales, cuya vigencia se remonta a la época medieval. Contrariamente a lo sucedido por entonces, y durante gran parte de los siglos XIX y XX, en la época de la globalización, los valores universales han sido revitalizados y utilizados como justificación de intervenciones armadas de las potencias polares.

Uno de los instrumentos más utilizados de la política del poder era, y lo sigue siendo, la formación de alianzas que sirvan a los intereses de la potencia que utilice los preceptos 
realistas. Es decir, que para debilitar a sus enemigos, el que gobierna, no debe dudar en hacer alianzas con los enemigos de sus enemigos, apoyar insurrecciones, sobornar, manipular intereses y, sobre todo, sus alianzas, no deben ser permanentes ni rígidas.

Una de las máximas más ejemplificadoras del pensamiento del cardenal Richelieu, en política exterior, es esta:

“...En cuestiones de Estado, el que tiene el poder a menudo tiene el derecho, y el que es débil sólo difícilmente puede no estar en el error, según la opinión de la mayoría..."20

La caída del comunismo soviético marcó el fin del sistema bipolar y puso en evidencia cómo un cambio en la estructura internacional, produjo una dispersión del poder acompañado de una exaltación del nacionalismo.

Si bien es cierto que Estados Unidos mantiene una supremacía militar con respecto a los otros actores internacionales, también es cierto que no pueden hacer cumplir su voluntad de manera inmediata, porque países como Alemania, Francia, Rusia, Japón y China, entre otros, alcanzaron la categoría de grandes y medias potencias lo que les da peso mundial.

Esta situación hace que Estados Unidos diagrame el cumplimiento de sus objetivos en un lapso de tiempo más prolongado y de forma gradual. En ésta diagramación de su política exterior se entrecruza la tradición de los valores nacionales con sus necesidades geopolíticas.

Pero, este contexto internacional, complica la supuesta actuación hegemónica de Estados Unidos como policía encargado de velar por la paz y la seguridad internacional. Por lo tanto, debe previamente o simultáneamente a su accionar, lograr un consenso internacional que lo legitime. Esta situación implica tener en cuenta la estructura internacional.

También se debe tener presente las contradicciones de la política exterior norteamericana, pues por un lado, prevalece la defensa de sus intereses vitales y, por el otro, promueve que la idea de que los valores democráticos deben ser los que rijan en el mundo obligándose, a sí mismos, a defenderlos, pero para ello debe incentivar el espíritu de cruzada internacional.

Esta situación, aparentemente, contradictoria se representó en la guerra de Kosovo, ella muestra, desde un principio, por qué el realismo resulta insuficiente para explicar el conflicto y, por el contrario, por qué el realismo estructural resulta más satisfactorio para justificarlo.

\section{Insuficiencia del realismo clásico para el análisis del conflicto}

Estados Unidos, para cumplir sus objetivos geoestratégicos, necesita de la cooperación de sus aliados europeos para asegurar la vigencia y robustez de la OTAN, y lo requiere a pesar de ser la única súper potencia con alcance global.

Esta necesidad de apoyo y colaboración europea se evidenció por el desvelo de los decisores políticos norteamericanos, ante los cuestionamientos de la opinión pública europea y, norteamericana, sobre la vigencia de la OTAN, aún después de desaparecida la amenaza del comunismo.

La teoría del equilibrio del poder analiza los resultados del obrar no coordinado de los Estados. Formulando premisas acerca de los intereses y objetivos de los Estados, en vez de explicarlos.

El enfoque neorrealista se diferencia de los tradicionales porque no sólo tiene en cuenta la explicación de la política internacional, su incidencia en el sistema internacional, las consecuencias de las decisiones de las unidades ínter-actuantes, sino porque, también, evalúa sobre los actores, en el ámbito sistémico, la influencia de la estructura internacional.

La importancia de la región europea y de los Balcanes para el interés norteamericano fue confirmada por el entonces, ex embajador de Estados Unidos ante la OTAN, Robert E. Hunter (actualmente consultor de la Rand Corporation) quien manifestara con relación a la guerra:

“...Kosovo constituye la puerta de entrada a regiones de interés primordial para los occidentales: El continente árabe -israelí, Irak e Irán, Afganistán, el Mar Caspio y el transcáucaso. La estabilidad de Europa del sur es esencial para la protección de los intereses occidentales y para la reducción de los peligros provenientes de más al Este..."21

\footnotetext{
${ }^{20}$ Brezezinski Zbigniew. (1998) "EL GRAN TABLERO MUNDIAL”. Barcelona. Piados. Pág. 67

${ }^{21}$ Washington Post, 21-4-99.
} 
Demostrada la importancia de la guerra de Kosovo para el desarrollo de la geoestrategia norteamericana, resta explicar por qué la estructura internacional incidió en las decisiones de los actores involucrados en el conflicto y en el comportamiento mismo del gobierno norteamericano.

Desde la finalización del sistema bipolar las Administraciones norteamericanas manifestaban que, con la caída del régimen comunista, se había iniciado un proceso de gestación hacia un nuevo orden internacional. Dicho orden estaría fundamentado en los valores democráticos, el respeto a los Derechos Universales del Hombre y el libre comercio.

La afirmación de que Estados Unidos posee la supremacía militar es aceptada por la mayoría de los analistas de la política internacional, así también existe consenso de que esa superioridad no es tan absoluta en los otros ejes de poder como lo es en el económico, el financiero y en cierta medida en el tecnológico. Esta difusión del poder y su creencia en los valores democráticos, además de las sospechas que despiertan sus acciones en el sistema internacional, obligan, a los estrategas y decisores políticos estadounidenses, a tener en cuenta la opinión de las otras potencias y en especial la de los aliados más importantes que integran la OTAN.

Los estrategas norteamericanos, con la finalidad de lograr los objetivos geopolíticos y, a sabiendas de la oposición de algunos miembros del Consejo de Seguridad como China y Rusia, respecto de la intervención armada de la Alianza Atlántica en Yugoslavia, y ante el debilitamiento del compromiso defensivo de algunos países europeos miembros de la OTAN, como Italia, Grecia, Hungría y la República Checa. Hicieron imperioso conseguir un marco de legitimidad internacional a la intervención armada, más aún cuando se le sumó el cuestionamiento generalizado de la opinión pública, norteamericana y europea, en especial por el costo del mantenimiento de la Alianza Atlántica, en desmedro al presupuesto nacional de asistencia social y educativa.

El fracaso de las negociaciones realizadas en Rambouillet y las consecuencias de la operación "hierro a caballo", puesta en ejecución en febrero de 1999 por el presidente Milosevic, brindaron el marco necesario para el logro de la ansiada legitimación internacional tanto de Estados Unidos como de los aliados más importantes dentro de la OTAN.

El 23 de marzo de 1999 el Secretario General de la OTAN, Javier Solana, ordena al Comandante Supremo Aliado en Europa (SACEUR) iniciar las operaciones aéreas contra la República Federal de Yugoslavia; con el objetivo de que la OTAN frenara una "catástrofe humanitaria".

El 24 de marzo, las operaciones aéreas se iniciaban con el nombre de "Allied Force" (Fuerza Aliada), los objetivos de la OTAN, eran terminar con los ataques de las fuerzas serbias contra los albanos -kosovares, neutralizar la capacidad de las fuerzas serbias para operar en Kosovo y, además, eliminar los sistemas de defensa aéreos serbios para resguardar de posibles daños a los aviones y a las tripulaciones de la OTAN.

La Secretaría de Estado norteamericana, se mostró renuente a brindar información sobre el posible empleo de fuerzas terrestres, no obstante, aseguró a la emisora estadounidense CNN que Estados Unidos estaba preparado para entrar en acción.

La preocupación de la Administración Clinton por la búsqueda de la legitimación de la intervención armada y de la utilización directa de la OTAN, como fuerza era el resultado consabido de que los decisores políticos norteamericanos supieran de antemano que, en el Consejo de Seguridad de la ONU, el mandato autorizando el uso de la fuerza no tenía posibilidades.

China, por múltiples razones, apelaría al veto y Rusia haría lo mismo, tal como quedó reflejado al vetar la permanencia de tropas de la ONU en Macedonia, a modo de castigo, por el inicio de relaciones diplomáticas entre Macedonia y Taiwán.

Estas circunstancias pusieron en evidencia las características del nuevo paradigma y, con ello, las particularidades de la configuración de la estructura internacional.

En el código realista la defensa y la seguridad de los intereses vitales de una nación esta garantizada en forma individual, no en términos de seguridad colectiva. Según el realismo estructural la garantía de la paz esta dada por la vigencia de un sistema de equilibrio del poder, pero en consideración a la interrelación del sistema internacional con la estructura internacional, como quedara demostrado en ocasión del conflicto en Kosovo. 
El realismo estructural sostiene que las partes de los sistemas políticos internacionales se hallan coordinados. Lo que significa que, en términos formales cada una de ellas, es similar a las restantes. Hlo implica que ninguna está autorizada a ejercer el mando sobre otras, así como ninguna está obligada a subordinarse.

Esta presunción determina que, a pesar de la existencia de las organizaciones internacionales y de la supuesta igualdad de los Estados entre sí, los actores supranacionales con capacidad efectiva de actuar tienen las siguientes alternativas: procurar tener algunos de los atributos y capacidades de los Estados, o de los relacionados Estados, o padecer la incapacidad de funcionar efectivamente si es que no cuentan con el apoyo de los principales Estados.

En consecuencia, la autoridad se reduce a una expresión de capacidad, aunque, limitada por las estructuras internacionales. En este sentido la OTAN, al ser una organización defensiva, permite, dentro de su marco organizativo, establecer entre los estados relaciones de coordinación pero, también, de jerarquía en estrecha correspondencia a las capacidades y atributos de cada Estado.

En el caso de Estados Unidos, la OTAN le permite una situación de privilegio (en la UE y entre los miembros de la OTAN) ya que es éste estado quien ejerce la "autoridad" efectiva dentro de la misma. Supremacía alcanzada por sus capacidades y atributos, tanto económicos como militares y tecnológicos; que por otro lado, les da confianza a los miembros socios, pues la organización, en sí misma, implica una limitación y obligación de la soberanía y autonomía de los Estados.

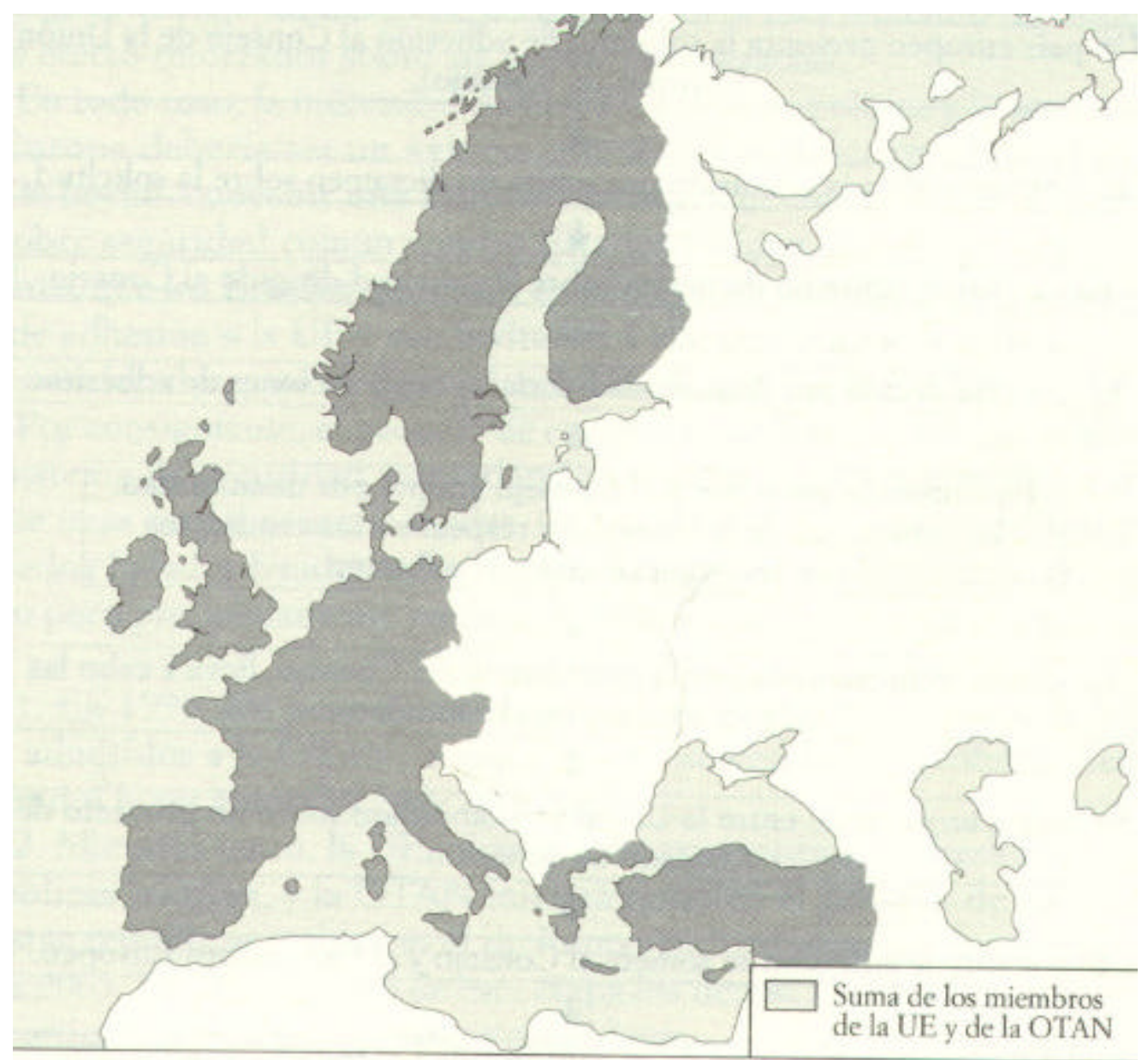

Fuente: Zbigniew Brzezinski, “El gran tablero mundial” 


\section{Análisis de la relación de los intereses nacionales estadounidenses en la conservación del sistema internacional}

La situación planteada en el punto anterior implica para Estados Unidos una relación problemática de orden global, ya que sus intereses nacionales estarían condicionados a la defensa y mantenimiento del sistema internacional.

Esta circunstancia muestra la relación de la política interna con la política externa. Estados Unidos manifestó que el objetivo de la intervención de la Alianza en los Balcanes, era terminar con las violaciones a los Derechos Humanos Universales y promover la defensa y vigencia de los valores democráticos. En consecuencia, entre los diversos objetivos, de la política exterior norteamericana, se halla el intento de modificar las estructuras políticas internas de los diferentes actores internacionales. Prueba de ello, es que los Estados que deseen integrarse a la OTAN, deben ser gobiernos democráticos.

Pero, contrariamente a ello el realismo clásico no está interesado en la transformación de las estructuras políticas internas de los Estados, porque, este enfoque teórico no acepta la creencia de que los sistemas democráticos de dichos Estados constituyan un requisito indispensable para la existencia de un sistema internacional más seguro y pacífico.

En Kosovo confluyeron algunas de las situaciones que constituyen lo que Paul Kennedy denominó nuevas amenazas que afectan al acontecer internacional. Ellas son:

a) la violación a los Derechos Humanos,

b) la desintegración de los Estados-nación

c) el resurgimiento de los nacionalismos y fundamentalismos religiosos.

Tales problemáticas tienen la particularidad de darse a escala mundial. A Estados Unidos, por ser la principal potencia global, le interesa mantener la estabilidad internacional al igual que a sus aliados europeos occidentales.

Kosovo representó la materialización de esta problemática, pues se trató de un problema global que, ante la limitación de los recursos y capacidades norteamericanas y europeas, permitió una solución más sencilla a los problemas porque tales medidas fueron realizadas en coordinación y cooperación de los Estados, dentro del marco de la estructura internacional actual.

Estados Unidos se interesó por la go bernabilidad glo bal ${ }^{22}$, no solo como consecuencia de su posición y jerarquía dentro de la estructura internacional sino también por las características de las amenazas que tienen lugar en el acontecer mundial. Pero, Norteamérica no puede llevar adelante sus objetivos geopolíticos sin contar con niveles aceptables de gobernabilidad global, en consecuencia, cuando la misma es amenazada se pone en marcha la mecánica del poder $^{\mathbf{2 3}}$ para resguardarla.

\footnotetext{
${ }^{22}$ Vale señalar aquí que a partir del año 1995 ha adquirido relevancia la cuestión de la "gobernabilidad Global”. Al respecto Fred Halliday, considera: “... en el actual contexto, se refiere a un conjunto de organismos interconectados, aunque separados, que comparten un propósito común. Por lo tanto, la gobernabilidad cubre las actividades de los Estados, pero también las de los organismos intergubernamentales, destacadamente los de la ONU, y el papel de las organizaciones no gubernamentales (ONG) y los movimientos trasnacionales: todos estos se combinan, influyéndose mutuamente, para producir el sistema de gobernabilidad global. La discusión no es sobre si dicho sistema es deseable o no: ya tenemos un sistema de gobernabilidad global con muchas capas, y por supuesto uno de los problemas principales es el de resolver, a través de reformas, los defectos de un sistema que ha estado vigente durante varias décadas..." Halliday Fred, "Gobernabilidad global: perspectivas y problemas". Revista Internacional de Filosofía y Filosofía Política. Madrid, N 9, junio 1997, p, 23

${ }^{23}$ Dallanegra Pedraza, Ob. Cit. Pág. 45-46. “... Cuando uno habla en términos de "mecánica del poder", lo hace atendiendo a la manera en que quienes utilizan el poder, manejan los principios de aplicación para obtener beneficios según criterios de "verdad" imperantes, que los propios aplicadores desarrollan, con el fin de "convencer" a los que son pasivos de poder, que es el costo que pagan por posibles perjuicios mayores que recibirían; trayendo como consecuencia que esa mecánica, busca
} 
La actitud de Estados Unidos y del resto de las principales potencias, desde la perspectiva del realismo estructural, se debe a que el sistema internacional es un sistema de auto-ayuda, por lo tanto, una de sus metas más importantes es evitar la alianza de las otras potencias menores en contra de su hegemonía, puesto que ello dificultaría el cumplimiento de los objetivos geopolíticos de las potencias polares. ${ }^{24}$

En consecuencia, Estados Unidos no puede comportarse como una potencia que vela de manera unilateral por la paz y la seguridad internacional. Por eso, en el nuevo sistema de seguridad internacional, lo específicamente militar quedó relegado del aspecto políticoestratégico; que es fundamental para la legitimidad.

Esta situación explica por qué, con motivo de la guerra de Kosovo, la OTAN pasa de ser una organización, específicamente militar a una que cada vez se parece más, a una estructura de seguridad con preeminencia político estratégico.

\section{Importancia del acontecer doméstico norteamericano y su relación con la guerra}

La Administración Clinton previó la posibilidad de que se produjera una escalda del conflicto, y con ello, el empleo fuerzas terrestres en la invasión a Kosovo y en otras regiones serbias. Para llevar adelante una política sobre un asunto tan controvertido, como éste, era necesario el apoyo del Congreso; sin este apoyo esa decisión hubiera sido prácticamente imposible.

La estructura política norteamericana está formada por un sistema de gobierno presidencialista, donde la división de poderes actúa como regulador, pues equilibra, entre sí, los poderes ejecutivo, judicial y legislativo.

Los principales críticos de la política exterior presidencialista provinieron del partido republicano, respaldados en el temor de la opinión pública estadounidense por las bajas que pudieran producirse. En el Senado se preguntaban por qué no dar a los europeos un rol más protagónico para que se hicieran cargo de las tareas de pacificación.

El presidente Clinton fue muy criticado por uno de los referentes más importantes del realismo, Henry Kissinger, éste le cuestionaba la forma en que manejaba la crisis y también criticó la excesiva dependencia, de los funcionarios, a las encuestas y opiniones de la ciudadanía.

Con la finalidad de alcanzar el apoyo, doméstico e internacional, a la política externa, los consejeros del presidente Clinton buscaron instrumentos políticos que legitimaran su discurso ante los críticos e indecisos. Esta situación generó una "Expectativa de Legitimidad", concepto que según Habermas Jurgen presupone:

“...que los sujetos solo consideran justificadas las normas que creen poder sostener en un discurso, es decir, en una discusión irrestricta y libre de coacción..."25

Esta dependencia nos indica que la Administración Clinton tuvo en cuenta la estructura interna de la sociedad norteamericana, en especial su estructura gubernamental. Este hecho indica la limitada autonomía de decisión de los estrategas encargados de diseñar la política exterior.

A la presidencia Clinton, también le preocupaba que, a consecuencia de la crisis, se produjera un aumento en el déficit fiscal que le impidiera cumplir con su promesa electoral, la

anular - y anula en la mayoría de los casos- toda conducta de resistencia, y posterga -o destruye toda posibilidad- los procesos que pueden llevar a una mayor autonomía.

“...La mecánica tiene que ver con el intervensionismo directo o indirecto; la utilización de la ayuda económica; el favorecer golpes de Estado para tener y mantener gobiernos funcionales, o gobiernos civiles dictatoriales que son funcionales a los intereses hegemónicos; el control de mercados; el control sobre los flujos financieros; el control sobre el desarrollo y/o la transferencia tecnológica, especialmente en áreas estratégicas; etc.,..."

${ }^{24}$ Cada actor internacional debería asegurarse la supremacía y seguridad en un sistema de auto-ayuda. Ello se debe a la ausencia de un gobierno central que regule al contexto internacional.

25 Habermas Jurgen, (1998) "PROBLEMAS DE LEGITIMIDAD EN EL CAPITALISMO TARDÍO". Argentina Grupo Editor Latinoamericano. Pág. 10 
que consistía en aumentar el presupuesto del área asistencial. Razón por la cual la guerra, se utilizó para lograr dicho aumento permitiendo cumplir con esta expectativa así como con las exigencias militares.

En el realismo clásico, esta circunstancia, no es trascendente porque la política interior está separada de la política exterior. Por el contrario en el realismo estructural, la interrelación de la política doméstica con la política exterior, es vital.

El argumento de la Administración Clinton, que con mayor frecuencia utilizó, fue manifestar públicamente que su intervención en la crisis respondía exclusivamente al compromiso asumido con la defensa y vigencia de los valores democráticos y del respeto a los Derechos Humanos, violados por el accionar de las fuerzas serbias.

En tal sentido, los funcionarios norteamericanos manifestaban, tanto a los medios de comunicación como al Congreso, que no sólo el prestigio de la Administración se encontraba en juego, sino también, la validez de los valores democráticos norteamericanos y su credibilidad internacional.

Lo expresado anteriormente se debió a que, en la participación norteamericana, se puso en juego tanto en las negociaciones como en las acciones armadas, el prestigio nacional y la capacidad de liderazgo internacional, pues Estados Unidos desempeñaba un papel muy importante en el effuerzo por lograr una solución a la crisis. Por ello, se enfatizó que, más que disminuir el posible coste del fracaso, la prioridad del Congreso debiera ser maximizar el éxito.

La incertidumbre sobre la escalda de la guerra era el producto de la desconfianza de los políticos y en especial de los militares a que, los civiles, interfirieran "en la esfera de sus asuntos". Los comandantes de las fuerzas armadas preferían que, los civiles, les encargaran una misión clara y bien definida, para luego decidir su implementación.

Esta impresión sobre las crisis, que conducirían a "misiones pantanosas", llevó a un duro debate en el Congreso entre sus integrantes y los militares, sobre cuál sería el papel de las fuerzas armadas norteamericanas en el mundo de la post guerra fría, el Pentágono no quería dividir sus fuerzas en objetivos primarios y secundarios, a causa de la limitación presupuestaria. Por ello, los comandantes plantearon, a la Administración Clinton y al Congreso, que no creían poder cumplir con objetivos secundarios y al mismo tiempo satisfacer sus misiones prioritarias.

A este planteo se sumó las opiniones del General retirado, Colin Powell, quien reclamaba un aumento del presupuesto militar. Este, en sus memorias, dejó en claro el pensamiento de los altos jefes militares:

“...Muchos de los de mi generación, capitanes, mayores y tenientes coroneles profesionales, madurados en esa guerra, juramos que cuando llegara el momento en que tuviéramos el mando no consentiríamos en silencio una guerra que no levantara entusiasmo y por motivos poco claros que el pueblo estadounidense no pudiera comprender 0 apoyar..."26

Los civiles se oponían a los despliegues militares, por ello la Casa Blanca evitaba confrontar a los militares, porque si éstos se oponían a un despliegue, aumentarían las dificultades del presidente Clinton. Dicho de otra manera, se necesitaba el respaldo mayoritario de los militares, para alcanzar el apoyo del Congreso y de los ciudadanos, para conseguir la intervención.

Según lo postulados de la "Realpolitikit", un verdadero practicante, hubiera alentado las acciones terrestres, sin importarle sus consecuencias humanitarias, y hubiese contado con un alto grado de autonomía doméstica para llevar adelante esas decisiones.

La Administración Clinton tuvo en cuenta en su decisión la política nacional, internacional, y los condicionamientos estructurales. Fue por eso que el planteo que utilizaron los estrategas políticos para vencer la oposición del Congreso y del Pentágono, fue un argumento que involucró objetivos íntimamente relacionados con los intereses norteamericanos nacional e internacional, como el tema de la OTAN.

\footnotetext{
${ }^{26}$ Powell Colin, con Joseph E. Pérsico (1994). "MY AMERICAN JOURNEY". Nueva York: Random House. Pág. 149
} 
La necesidad de coherencia, del apoyo a la intervención, radicaba en que Estados Unidos no podía adoptar una postura ambivalente, de apoyo y desinterés, en el accionar de la Alianza. Por otro lado, para lograr el apoyo de la opinión pública, se resaltaron, a través de los medios de comunicación, las implicancias del concepto de limpieza étnica y de otros crímenes de guerra.

Asimismo, ésta maniobra política, además de perseguir un fin doméstico, tenía el efecto de incrementar la presión sobre Milosevic, para que terminara con tales violaciones. Durante las negociaciones, y simultáneamente a las acciones armadas, el Tribunal Internacional para los crímenes de guerra, con sede en La Haya, resultó ser vital, aunque imperfecto.

El Tribunal constituyó un importante instrumento político que permitió a Estados Unidos y sus aliados, impedir que, Milosevic y otros acusados por crímenes de guerra, pudieran salir de Serbia y participar en negociaciones internacionales, ya que si éstos eran capturados en el extranjero serían sometidos a juicio.

Esta situación era muy útil a la estrategia norteamericana, porque contribuía a conseguir el aislamiento diplomático de Milosevic, como paso con Saddam Hussein durante la Guerra del Golfo 1990-1991.

La participación, decidida y coherente, de Estados Unidos en la guerra tendría la ventaja de lograr el control material y psicológico del proceso, además de reforzar el convencimiento en los europeos de que su presencia era necesaria en Europa. Y con ello, reafirmar, ante las potencias polares, su supremacía internacional.

\section{Tensión entre los intereses nacionales y las necesidades exteriores Norteamericanas}

El problema planteado al gobierno norteamericano consistía en responder satisfactoriamente a la siguiente pregunta:

\section{¿ Cómo puede conciliarse la tensión existente entre los intereses nacionales y la necesidad de actuar para la supervivencia del sistema?}

Los que creían y creen en la "realpolitik", como George Kennan, Richard Nixon, Henry Kissinger, manifestaron que, la defensa de los derechos humanos por parte de los EE.UU., no era conveniente, pues, además de intervenir en los asuntos internos de otras naciones, causaba fricción con los intereses de la seguridad nacional de Estados Unidos y debilitaba sus intereses estratégicos y comerciales.

Sin embargo, desde la perspectiva del realismo estructural, Estados Unidos no puede comportarse como si fuera un Estado "común" porque no lo es. Sus extraordinarias capacidades y su posición dentro del sistema le imponen asumir el rol protagónico que otros Estados no pueden llevar a cabo, teniendo en cuenta que estos últimos carecen de capacidad y de incentivo.

Kenneth Waltz, considera que las tareas que deben llevar adelante un Estado poderoso, en orden decreciente de importancia, son las de transformar o mantener el sistema, preservar la paz y el manejo de la economía entre otros problemas comunes.

La desaparición de la Unión Soviética, permitió a Estados Unidos alcanzar una supremacía global. Poder que manifiesta el carácter pluralista de la sociedad estadounidense y de su estructura política, cuyo diseño es propio de Norteamérica y que da cuenta de la experiencia doméstica del país. Sin embargo, la opinión pública estadounidense, con respecto a la proyección externa del poder norteamericano, fue dubitativa. Las encuestas de opinión pública, realizadas en 1995 y 1996, reflejaron que la mayoría de los ciudadanos aspiraban a que su gobierno distribuyera las obligaciones del poder global con otros, en lugar de ejercerlo como monopolio.

Los partidarios del realismo consideran que una Europa unida sería contraproducente. Henry Kissinger así lo afirmó en su libro "Troubled Partnership", sobre la Alianza Atlántica. Él creyó que una Europa unida habría de ser un bastión en contra de la Unión Soviética, pero que una Europa de Estados separados sería más proclive a negociar con el líder de una alianza. 
Ahora bien, desde el punto de vista de la teoría neorrealista las partes débiles tienden a combinarse para establecer un equilibrio $y$, de este modo, tratar de igualar el poder del más fuerte.

Según esta teoría, entonces; Rusia procuraría lograr una alianza con Europa y, esta última, se beneficiaría porque, en la supuesta alianza, los europeos serían los socios más fuertes, pues habría incrementado su poder para rivalizar con el liderazgo norteamericano.

Esto no escapa de los analistas políticos, es decir, los temores ante la posibilidad de un arreglo bilateral entre Alemania y Rusia. O bien, un acercamiento oportunista de Francia con Moscú lo que traería una preocupación geopolítica en Europa.

Un retraimiento de la participación americana en Europa provocaría, como reflexiona Zbigniew Brezezinski, en su libro "El gran tablero mundial", que Europa deje de ser cabeza de puente euroasiática para los estadounidenses, puesto que pasaría a ser el potencial trampolín, de la expansión de Eurasia dentro del sistema global democrático ${ }^{27}$.

El ejercicio del poder global norteamericano trajo como consecuencia que, el interés de seguridad de Estados Unidos, se vinculara con el sostén de un determinado orden internacional. Situación que se corresponde con el pensamiento de Kenneth Waltz, quien dice al respecto:

“...Para los países que se hallan en la cima, ésta es una conducta predecible. Necesariamente mezclan sus exageradas preocupaciones por la seguridad con la preocupación por el estado del sistema. Una vez que los intereses de un Estado alcanzan determinado grado, se tornan auto-estimulantes. Al intentar el logro de un orden de seguridad internacional, Estados Unidos promovió al mismo tiempo sus intereses económicos y dio expresión a sus aspiraciones políticas..."28

La crisis de Yugoslavia fue útil a la geoestrategia norteamericana, pues le permitió conciliar sus intereses nacionales con su necesidad de sostener el orden internacional. Entonces:

¿Cómo hacer para que las cargas globales de Norteamérica fueran compartidas por la Unión Europea, luego de que ésta se transformara en un tercer gran poder?

Para tratar de responder esta cuestión habría que considerar las implicancias de un fracaso norteamericano en el conflicto de Kosovo.

En la guerra de Kosovo, a diferencia de la guerra de Vietnam (1965-1973), había algo más en juego que el honor y la credibilidad norteamericana, tal como fuera manifestado en las declaraciones oficiales sobre el conflicto asiático. Para el análisis de éste hay que tener presente el concepto de estructura internacional de Kenneth Waltz.

El desastre norteamericano en Vietnam, fue aceptado porque ni el éxito ni el fracaso hubieran generado grandes cambios en el plano mundial. Un triunfo no hubiera convertido al mundo en una hegemonía estadounidense, así como tampoco aquella derrota transformó al mundo en una hegemonía soviética. Por el contrario una derrota o fracaso norteamericano en la guerra de Kosovo hubiera sembrado dudas sobre su capacidad de liderazgo en el ámbito mundial y sobre todo ante sus principales aliados europeos, porque ello hubiera ocurrido en momentos en que se discutía la ampliación de la OTAN, a lo que se hubieran sumado las constantes críticas sobre la efectividad de la existencia de la Alianza Atlántica luego del derrumbe del comunismo.

Un fracaso de los Estados Unidos y una perdida del prestigio de la OTAN, sin duda ocasionarían la imposibilidad del reforzamiento y ampliación de la Alianza Atlántica. Consecuentemente, se pondría en grave riesgo a los grupos democráticos de la dirigencia política moscovita y a las relaciones entre Estados Unidos con Rusia y los países musulmanes.

A partir de este proceso de racionalización vemos cómo, los estrategas de la Casa Blanca, recrearon un discurso práctico que instituyó, en los miembros del Congreso y la opinión pública, la creencia en la legitimidad de la intervención armada norteamericana.

\footnotetext{
${ }^{27}$ Brezezinski Zbigniew, mentor de la Secretaría de Estados Unidos, Madeleine Albrigh.

${ }^{28}$ Waltz K. Op. cit, Pág.. 291
} 
Esta creencia de legitimidad, se fundamentó en una estructura de comunicación y propaganda que también abarcó el ámbito internacional. La estrategia discursiva en pro de la legitimación tuvo efectos positivos.

En tal sentido, puede destacarse que el 23 de marzo de 1999, el presidente Bill Clinton, recibió a los integrantes del Congreso en la Casa Blanca para pedirles que apoyaran "cualquier acción militar". Con este hecho logra que los senadores republicanos renunciaron a presentar una enmienda contra las incursiones aéreas en Yugoslavia y dieron su apoyo a la resolución, autorizando al presidente a iniciar una acción militar y aprobando el presupuesto militar que excedía las necesidades operativas, fue así que el 20 de mayo, el Senado de los Estados Unidos dio su aprobación a un paquete de $\mathbf{1 5 . 0 0 0 ~ m i l l o n e s ~ d e ~ d o ́ l a r e s ~ p a r a ~ f i n a n c i a r ~ e l ~ b o m b a r d e o ~}$ contra Yugoslavia y mejorar la capacidad militar del país.

Dinero que casi duplica la suma solicitada por el presidente Bill Clinton para financiar la operación lanzada por la OTAN. Esta circunstancia llevó a manifestar al mandatario, que:

“Dará a nuestros militares lo que necesitan para culminar su misión, a la vez que mantendrá la preparación de nuestras fuerzas en todo el mundo.."29

Pero también, se dirigió a los ciudadanos estadounidenses para persuadirlos de la urgencia de los ataques militares contra objetivos serbios para impedir un genocidio en la provincia serbia de Kosovo.

Como el presidente Clinton tenía objetivos geopolíticos a favor de la intervención armada, argumentó que la misma era necesaria para los valores más sustanciales del pueblo norteamericano y de las democracias occidentales, describiéndola como la defensa de los valores universales del Hombre y de la cultura occidental.

La violencia un instrumento viable para alcanzar los objetivos políticos

Cuando se produjo la escalada de la crisis, la Casa Blanca resolvió hacer uso de la fuerza armada, y como máximo responsable político impuso en el análisis de la situación la pregunta que sigue:

\section{¿Es la violencia el instrumento más viable para la resolución de la crisis y el camino más directo para alcanzar los objetivos políticos, cuando los medios diplomáticos han fracasado?}

En la situación planteada puede apreciarse una contradicción, aparente, pues la solución de la crisis, para el presidente Milosevic, estribaba sobre la utilización de la fuerza, lo que Estados Unidos y la Unión Europea, en teoría, querían evitar porque temían que el conflicto se extendiera a los países limítrofes. Sin embargo, tanto los Estados Unidos como los miembros principales de la Unión Europea, no dudaron en hacer uso de la fuerza con la finalidad de imponer su ley.

Una vez planteado, el cuestionamiento anterior, como ajeno a la política del poder, a la dirigencia norteamericana le fue difícil la definición de objetivos prácticos en la guerra; pues las metas de la OTAN, declaradas públicamente junto con los ataques, consistían en detener la acción de las fuerzas serbias y debilitar la capacidad de reacción de los sistemas de defensa aéreos de los militares serbios en Kosovo, para evitar bajas entre los efectivos de la Alianza.

El objetivo político establecido, por los funcionarios de la Administración de Clinton, era terminar con el genocidio, del que era victima la minoría albano-kosovar, lograr la detención de los culpables de los crímenes, en especial la de Milosevic, y favorecer la instauración de un efectivo sistema democrático pro-occidental en Belgrado.

Jean-Baptiste Duroselle en su libro "Todo imperio perecerá", establece que todo líder, encargado de tomar la decisión de ir a la guerra, debe dar cuenta de una serie de interrogantes antes de pronunciarse a favor de ella. Dichos interrogantes, en términos generales, dan cuenta:

${ }^{29}$ La Nación. 21-5-99. Pág. 2 
1. fuerzas militares disponibles de inmediato

2. duración del conflicto

3. el potencial

4. los riesgos eminentes de la acción. ${ }^{\mathbf{3 0}}$

Las fuerzas serbias habían sido gravemente dañadas, sin embargo, su capacidad de lucha no había sido del todo destruida puesto que en el caso de una invasión terrestre de la Alianza Atlántica las bajas aliadas podían ser considerables.

Estados Unidos estaba en una posición sin retorno pues su intervención armada había sido producto del análisis de factores internos y externos, solo entendible desde la perspectiva del neorrealismo..

La Casa Blanca era consciente de que, en el ámbito de las Naciones Unidas y, específicamente, en el del Consejo de Seguridad, la prosecución de las acciones militares se toparía con las negativas de Rusia y China, quienes podrían ejercer el derecho de veto y acabar con las hostilidades.

Si las negociaciones de la crisis se trasladaban, del ámbito de la OTAN, al de las Naciones Unidas, se hubiera decretado el alto al fuego. Situación que hubiese expuesto a Estados Unidos tanto en el ámbito de la escena política doméstica como en el internacional, destruyendo su liderazgo y afectando la vigencia misma de la OTAN. Pero a pesar de ello, la mayoría de los miembros de la Alianza Atlántica así como los de la Naciones Unidas se mostraron reacios porque temían una escalada de la guerra.

El presidente Clinton, para demostrar la eficacia de sus fuerzas y el de la OTAN, y a la vez lograr el cumplimiento de sus objetivos políticos debía castigar a Serbia, pero sin provocar una guerra mayor. Por eso Washington, se esforzó en convencer a los actores internacionales, con capacidad de agravar el conflicto como Rusia, China e Irán, de que los objetivos de la OTAN eran limitados. Igual esfuerzo puso, para lograr lo mismo en el ámbito nacional.

Los consejeros políticos y militares de la Casa Blanca advirtieron al presidente Clinton, que una escalada en la guerra aumentaría los costos de la intervención. Si bien la opinión pública norteamericana estaba a favor de evitar las violaciones a los derechos humanos de la minoría albano-kosovar, su apoyo mermaba significativamente si ello implicaba verse comprometidos en "una misión pantanosa".

A pesar de los cálculos, del análisis de los riesgos implícitos de la acción y de haber adoptado una estrategia de acción ejecutada por la Fuerza Aérea de la OTAN, la misma fue muy criticada porque se consideraba a dicha estrategia como la responsable de la dilatación de una rápida victoria. Aunque esa dilatación, fue el producto de la preocupación del presidente Clinton por la seguridad de los soldados estadounidenses y por las consecuencias políticas internas.

Según los postulados de la teoría realista, esta situación refleja una contradicción, puesto que la guerra misma pone en riesgo la integridad de los combatientes. Además, la posibilidad de una escalada del conflicto siempre se halla implícita en la decisión de intervenir.

La teoría del poder enuncia que, en una guerra, la nación que participa debe estar dispuesta a utilizar todo su potencial para la consecución de sus objetivos políticos y militares.

Esta argumentación la utilizaron figuras como Henry Kissinger y Colin Powell para criticar a la estrategia de Clinton, como la responsable de la prolongación de la guerra y de la resistencia del gobierno del presidente Milosevic.

Según estos críticos el presidente Milosevic conocía las declaraciones de los funcionarios de la Administración Clinton; en otras palabras que aquél sabía que los estadounidenses no estaban dispuesto a escalar operaciones terrestres que pondrían en riesgo la vida de los soldados norteamericanos.

La cuestión que se le planteaba a la Administración Clinton, no se reducía a ofrecer un argumento convincente para lograr el despliegue de las tropas estadounidenses en Kosovo, porque la mayoría de los norteamericanos así como el Congreso, se encontraban muy sensibilizados por las imágenes de los cadáveres de los soldados americanos, arrastrados por

\footnotetext{
${ }^{30}$ Dada la importancia de los conceptos vertidos en este libro y del análisis realizado sobre la base de los mismos, para el caso de Kosovo, se invita a los interesados al Anexo $\mathrm{N}^{\circ} 1$ al final de esta tesis.
} 
las calles de Somalia y por el peligro inminente de verse inmersos en un conflicto sin salida. Lo que implicaba una predecible imposibilidad política en Kosovo. Entonces:

¿ Cómo revertir esta percepción en los ciudadanos sobre los riesgos de la intervención; cuándo las enseñanzas de las guerras de Vietnam y Kuwait, habían demostrado que el uso del poder aéreo no era efectivo, a menos que estuviera complementado con el uso de fuerzas terrestres?

Un pensamiento manifestado por el coronel de US Army, John Weeks, hace bastante años, decía:

“...Ustedes pueden guardarse sus armas atómicas y sus aviones, pero todavía habrán de tener un chico con un fusil y bayoneta que saque al otro bastardo de su pozo de tirador y le lleve a firmar el tratado de paz..." ${ }^{31}$

Reflexión que la mayoría de los analistas compartían sobre la actitud de la OTAN y de la inhibición de Estados Unidos para comprometer las tropas terrestres en su ataque a Serbia.

\section{Estrategia de Estados Unidos para la intervención armada en Kosovo}

\section{Características:}

Del análisis de la evolución del conflicto y del comportamiento de la Administración Clinton, se deduce que la estrategia estuvo orientada a incentivar y regular, dos fenómenos sociales, el espíritu jingoísta y la pulsión social.

Con el propósito de cambiar la percepción de la opinión pública y tratar de influir en su conciencia, fue necesario una presión psicológica, en otras palabras realizar una manipulación de los medios de propaganda y de comunicación desde el gobierno.

El jingoísmo consiste en propiciar la sensación de placer ante el peligro virtual en el espectador, sin esfuerzo personal, riesgo o sacrificio. El sentimiento jingoísta evita toda referencia de sacrificios y de duras privaciones que forman parte de una campaña militar prolongada. En el desarrollo de este espíritu los riesgos de la guerra parecen hasta imposibles, dicho de otra manera, el espíritu jingoísta, actuaría como un factor redentor de la guerra. A través de él, el soldado profesional adquiere magnificencia. Y ello exige en forma implícita que las guerras sean de corta duración, para no recurrir al reclutamiento masivo.

Esta circunstancia, nos permite comprender la contención de los Estados Unidos hacia la utilización de las fuerzas terrestres y entender la lógica de basar la intervención en la fuerza aérea y en las fuerzas especiales; motivo por el cual se daba a conocer imágenes en tiempo real de cómo los mísiles inteligentes destruían los blancos con una precisión casi "quirúrgica", y sobre todo para que se vea que no había riesgos para los pilotos y que se ocasionaba pocas victimas inocentes.

Esto también explicaba por qué casi toda la confrontación terrestre estuvo a cargo del Ejército de Liberación de Kosovo (ELK), el cual aumentó su número de efectivos pasando de 5000 hombres, a principios de 1998, hasta alcanzar una cifra cercana a 15.000, en 1999.

EI ELK era una fuerza guerrillera, que no disponía de una potencia de fuego capaz de oponer una resistencia efectiva a las fuerzas serbias.

El otro fenómeno social que fue necesario regular e instrumentar era la pulsión social. Ella hace referencia a una "fuerza profunda", que surge del conjunto de los individuos que forman una sociedad, y que es expuesto por situaciones que van más allá de lo tolerable por las pautas culturales y los valores sociales imperantes en una sociedad dada.

En palabras de Jean Baptiste Duroselle, la pulsión consiste en:

“...Ante todo, es masiva, difusa, oscura, profunda. Ciertamente, diversos organismos van a tratar de adueñarse de ella, de esforzarse por recuperarla..." 32

\footnotetext{
${ }^{31}$ Garcia Dionisio, (1999) “Ataque contra Yugoslavia. El dispositivo terrestre”, Revista Soldiers Raids, Número 46. Madrid, julio.
} 
La táctica de los estrategas políticos de la Casa Blanca, consistió en manejar los medios de comunicación y de propaganda para lograr una manipulación social y lograr una presión sobre la conciencia de los ciudadanos y de la opinión pública mundial.

Al incentivar un sentimiento de ira generalizada por las violaciones de las fuerzas serbias, a los Derechos Humanos Universales y al ejercicio de las libertades fundamentales, sobre la etnia albano-kosovar, se buscó catalizar el fenómeno de pulsión social para facilitar el apoyo de los ciudadanos en favor de la causa aliada.

En consecuencia, puede verse cómo, el desarrollo del espíritu jingoísta y el intento de regulación de la pulsión social, estuvieron interrelacionados para facilitar la estrategia de intervención aliada.

\section{Opciones entre el estancamiento y la escalada de la guerra}

Antes que analizar las recomendaciones dadas para el inicio de las operaciones terrestres, es necesario plantear el siguiente interrogante:

\section{¿Existía alguna opción entre el aparente estancamiento y la escalda de la guerra?}

Las críticas sobre la ineficiencia de la guerra aérea y la necesidad de ser completadas con operaciones terrestres causaron temor entre los miembros de la OTAN. Ello dio un mayor margen de maniobra y tiempo a Milosevic.

Iniciar una invasión terrestre sobre territorio serbio hubiera sido interpretado como una declaración de guerra total contra el pueblo serbio, no ya contra un "tirano genocida" como fuera llamado Milosevic por los funcionarios de la Casa Blanca y de la OTAN, aunque éste fue elegido democráticamente.

La invasión terrestre de la Alianza involucraría a Estados Unidos, en un conflicto prolongado y costoso. Asimismo, resulta dudoso suponer una actitud pasiva de Rusia y de China, ante una invasión terrestre de la OTAN sobre Serbia.

Según los críticos, desde el concepto del realismo y de la teoría del poder, las precauciones de la Administración Clinton mostraban un efecto negativo, ya que la moderación del empleo de la fuerza permitió a Serbia aliviar la situación de deterioro que estaban sufriendo su ejército e infraestructura; como consecuencia de la superioridad técnica y material de los aliados y en especial de Estados Unidos.

Durante este período de indecisión, los militares serbios construyeron posiciones casi invencibles a través de un difícil terreno montañoso que brindaba obstáculos naturales como defensas. Lo que eliminaba la posibilidad de que la OTAN obtuviera una rápida victoria.

Desde la perspectiva del realismo estructural, que explica la relación entre política interna y externa, además de la mutua interrelación de las unidades ínter-actuantes con la estructura internacional, es posible comprender las indecisiones e inhibiciones de la Casa Blanca para escalar la guerra.

Un gran número de bajas de la OTAN, produciría la pérdida del espíritu jingoísta en la opinión pública, esta situación acarrearía el efecto indeseado de la "pulsión social", pues un costo excesivo de la guerra generaría un profundo descontento en la sociedad.

\footnotetext{
${ }^{32}$ Duroselle Jean Baptiste. Op. cit., pág. 175
} 


\section{Capítulo IV Las dudas del enfoque Interdependentista}

\section{Supuestos básicos de la teoría de la interdependencia}

La teoría de la interdependencia en cascada, según James $\mathrm{M}$. Rosenau, se basa en modelos de interacción en rápido cambio, entre fenómenos tales como "escasez de recursos, subagrupamiento, la eficacia de los gobiernos, los temas transnacionales y la actitud del público. La interacción de estos fenómenos ha dado lugar a lo que este autor denomina "tensiones entrelazadas, que, al estar entrelazadas, sacan fuerza y dirección la una de la otra y se derraman en cascada a través de todo el sistema global" 33

Este autor cree, que la aparición de subgrupos significa que la lealtad de los individuos ha cambiado de una entidad mayor a una menor, lo que ha producido un debilitamiento de la autoridad del estado-nación establecido. Como consecuencia de ello, la interdependencia en cascada, tiene el efecto de distribuir poder de manera errática y entre entidades estatales y numerosos subsistemas en varios niveles. ${ }^{34}$

La teoría de la interdependencia concibe al sistema internacional como la combinación de distintos segmentos de los Estados nacionales con intereses específicos. Habla de un mundo transnacionalizado y de la interdependencia que se establece entre las partes. El je del poder es multipolar y la agenda internacional es compleja, amplia y desjerarquizada. Coexisten nuevos y múltiples agentes y la relación que se establece entre ellos es de fluida cooperación. Los Estados-nación estarían predispuestos a estimular la cooperación, en instituciones y regímenes del sistema global, para facilitar la regulación de un comportamiento multilateral.

En consecuencia, la estructura anárquica del mundo es vista como un sistema de contrastes balanceados, que permite la cooperación y limita el interés a todos los Estados, de alcanzar metas nacionales.

Aunque; el crecimiento de la interdependencia tenga el efecto de debilitar el poder y la soberanía de los Estados, permite el surgimiento en la escena internacional de otros actores que se caracterizan por la tendencia a la cooperación; cuyo resultado es un nuevo contexto internacional que se diferencia por la existencia de Organizaciones no gubernamentales (ONG), corporaciones especializadas multinacionales, movimientos sociales, Organizaciones especializadas en el Medio Ambiente o Humanitarias que se inclinan hacia las soluciones cooperativas, como una forma de participar de un "gobierno global".

Autores, como James M. Rosenau, que adhieren al enfoque de la interdependencia, creen que a finales del siglo XX, el sistema internacional ha ingresado a una época que lo identifica como "interdependencia en cascada".

En consecuencia, quienes adhieren al concepto de "interdependencia en cascada" creen que la misma aporta un fundamento para el estudio de las relaciones de poder. Las fluctuantes circunstancias sociopolíticas y los mecanismos de adaptación de los sistemas, sobre los que esté presente el uso de la fuerza o la posibilidad de una conducta cooperativa, encuentran su explicación en dicho concepto.

\section{Análisis de la interdependencia, desde la perspectiva del realismo estructural}

El realismo estructural, sostiene que la política mundial no está formalmente organizada, pero que posee instituciones y procedimientos ordenadores. Esta situación provoca en los estudiosos de la interdependencia una percepción disminuida de la anarquía durante la producción de alianzas, en los intercambios comerciales internacionales y cuando se multiplican las agencias internacionales.

\footnotetext{
${ }^{33}$ Dougherty James E. y Pfaltzgraff Robert L. (1993) “Teorías en pugna en las relaciones internacionales”. Buenos Aires, Grupo Editor Latinoamericano, pág.. 152.

${ }^{34}$ Rosenau James M. “A Pre-Theory Revisited: World Politics in an Era of Cascading Interdependence”, International Studies Quarterly, Vol. 28, N²8, (September de 1984), pág. 264.
} 
Los seguidores de la interdependencia, según Kenneth Waltz, confunden estructura con proceso, ya que creen que los elementos jerárquicos de las estructuras internacionales limitan y restringen el dominio de la soberanía. Pero ello ocurre sólo de manera condicionada a causa de la anarquía del sistema mayor, pues la anarquía de ese orden afecta con firmeza las probabilidades de cooperación, la profundidad de los acuerdos de desarme y la jurisdicción de las organizaciones internacionales.

El neorrealismo crítica el mito de que la interdependencia promueve la paz, es decir, cree que oscurece las realidades de la política internacional.

Desde el punto de vista económico, significa que los costos y las posibilidades de una ruptura de Estados Unidos con sus socios comerciales europeos no producirían efectos catastróficos; ya que las otras naciones dependen más de los norteamericanos, que estos de aquellos países.

Similar punto de vista se puede aplicar sobre la seguridad, si bien la OTAN es importante para la geoestrategia norteamericana en la guerra de Kosovo, la incapacidad de los europeos para resolverla sin la participación estadounidense, puso de manifiesto la dependencia europea de los Estados Unidos; y ello a pesar de que la Unión Europea representa un poderoso polo económico y de que aspira serlo también desde lo militar, finalizada la guerra fría.

La hegemonía norteamericana se manifiesta de diferentes formas, ya sea a través de la concesión de facilidades a otros países, o bien por medio del ejercicio de presiones comerciales, negándose a otorgar préstamos o a dar tecnológica con propósitos pacíficos o de seguridad. Todo ello dependerá de la predisposición de los otros países para cumplir con las políticas diagramadas por los Estados Unidos.

El neorrealismo considera que esta circunstancia de privilegio de los Estados Unidos, se debe a que sus capacidades le permiten un mayor margen de control y que, al mismo tiempo, los protege de los otros actores internacionales.

Sin embargo, los partidarios del realismo estructural sostienen que, las desigualdades entre las naciones, producen una situación de equilibrio con bajo nivel de interdependencia. Esta es una descripción del mundo muy distinta a la que adscriben los simpatizantes de la interdependencia.

La promesa de establecer una geografía europea donde prevalecieran los valores democráticos y la vigencia de las libertades fundamentales que faciliten una auténtica integración continental luego de la guerra fría, chocó con la guerra en los Balcanes.

\section{Valorización del Derecho Internacional Público}

Desde el pensamiento de la interdependencia la conducta a implementarse en Kosovo tendría que haberse basado en el seguimiento y respeto del Derecho Internacional Público (DIP) Sin embargo, su implementación presentó contradicciones sobre estas cuestiones básicas.

Una primera cuestión a establecer, basados en los postulados del DIP, es identificar claramente a quiénes de los actores intervinientes asiste el derecho en sus reclamos territoriales, es decir, a los albano-kosovares que eran mayoría o los serbios que representaban a la minoría.

El presidente Milosevic declaró que tenía derecho a ordenar la intervención de sus fuerzas armadas en Kosovo para evitar una secesión de una fracción del territorio perteneciente a una provincia de la República Federal de Yugoslavia (RFY). Los portavoces de la RFY, por su parte, sostuvieron que el conflicto consistía en una insurrección armada con el propósito de formar un Estado independiente dentro del territorio serbio.

Los albano-kosovares, a su vez, argumentaron que constituían una nación subyugada y dominada por el Estado serbio, un poder extranjero y que, por lo tanto, los asistía el legitimo derecho de reclamar y luchar por su independencia.

A partir de la situación planteada se evidencia la complejidad del caso, ya que, desde el DIP, a ambas partes del conflicto, les asiste la razón.

Así el gobierno de Belgrado tiene derecho a defender su soberanía sobre la provincia de Kosovo, ya que desde el año 1300 forma parte del territorio de Serbia. Cuando el uso de la 
fuerza fue reconocido por el D.I.P en 1912, los serbios guerrearon contra los turcos y al conquistar la región, Kosovo formó parte de la RFY hasta la Constitución de 1992. Donde, el derecho al reclamo del Estado, se halla amparado por el Artículo 2. inciso 1 de la Carta de la ONU, que establece la "igualdad soberana" de los países firmantes y, en el Artículo 2 inciso 4, reconoce como un principio fundamental la "integridad territorial y la independencia política de cualquier Estado".

Sin embargo, los reclamos albano-kosovares también tienen basamento jurídico, pues argumentaron que tenían el derecho de luchar por su independencia, por haber padecido el dominio del Estado serbio y por haber sido ocupantes del territorio permanente.

Por estas razones, los albano-kosovares, consideran que su causa es justa y que está amparada por la Carta de la ONU que, en su Artículo 1 inciso 2, establece que las naciones deben promover relaciones amistosas entre sí "basado en el respecto de derechos y autodeterminación de los pueblos".

La misma posición es reforzada por la Resolución 1514 (XV) de la Asamblea General de la ONU, donde se establece que "todos los pueblos tienen el derecho a la autodeterminación... y el derecho a determinar libremente su estatus político" sin importar su situación "política, económica, social o educacional".

En consecuencia, la guerra de Kosovo pone en evidencia la ambigüedad de las normas del DIP, ya que brindó las fuentes para elaborar argumentaciones a ambos beligerantes, para lograr la legitimación internacional. Ambigüedad que quedó reflejada en la Resolución 1160 (1998), aprobada por el Consejo de Seguridad el 31 de marzo de 1998, donde establece:

"Concuerda, sin prejuicio de los resultados que arroje ese diálogo, con la propuesta formulada en las declaraciones del Grupo de Contacto de fechas 9 y 25 de marzo de 1998 en el sentido de que los principios relativos a una solución para el problema de Kosovo deberían basarse en la integridad territorial de la República Federativa de Yugoslavia y ajustarse a las normas de la OSCE, incluidas las establecidas en el Acta Final de Helsinki de la Conferencia sobre la Seguridad y la Cooperación en Europa de 1975 y en la Carta de las Naciones Unidas, y de que esa solución debe también tener en cuenta los derechos de los albaneses de Kosovo y de todos los que viven en Kosovo, y expresa su apoyo a un mejoramiento de la condición jurídica de Kosovo que entrañe un grado sustancialmente mayor de autonomía y de administración propia satisfactoria; ..." ${ }^{35}$

Pero, a su vez, también ambos actores han violado el DIP. Por un lado, los serbios masacraron y provocaron el éxodo masivo de los albano-kosovares. Por otro lado, los albanokosovares por medio del ELK cometieron crímenes de lesa humanidad, pues mujeres, niños y ancianos también fueron víctimas en sus ejecuciones sumarias.

\section{Conducta de Estados Unidos y de la OTAN en el conflicto}

Otro actor internacional importante en el conflicto es la OTAN, organismo liderado por los Estados Unidos, Gran Bretaña, Francia y Alemania quienes han justificado su intervención militar en Kosovo, en la necesidad de poner fin a la violación de los derechos humanos.

La estrategia de justificación de la OTAN fue diagramada principalmente por los norteamericanos, quienes se basaron en el compromiso asumido en el acuerdo de Dayton (nov. 1995), por el gobierno de Belgrado; en el que se comprometían a respetar los derechos humanos y a permitir que observadores internacionales y una fuerza militar denominada “Fuerza de Implementación" velara por el cumplimiento de lo pactado.

Esta "Fuerza de Implementación" pertenecía a la Alianza Atlántica pero su control estaba ejercido por la ONU. Es decir, que el órgano que poseía la máxima autoridad era el Consejo de Seguridad (CDS) para velar por el cumplimiento del acuerdo.

Ahora bien, ello no fue un impedimento para que la OTAN decidiera su participación, aunque esta decisión significara una clara violación al DIP, norma que decía defender. La Carta de la ONU, en su Artículo 24-1 establece:

\footnotetext{
${ }^{35}$ RESOLUCIÓN 1160 (1998) Aprobada por el Consejo de Seguridad en su 3868 a sesión, celebrada el 31 de marzo de 1998.
} 
“Los miembros de las Naciones Unidas le confieren al Consejo de Seguridad la responsabilidad primaria para el mantenimiento de la paz y seguridad internacional..." ${ }^{36}$

Es evidente que el derecho internacional fue violado por los miembros de la OTAN de manera consciente con la fnalidad de poner en práctica la estrategia que le posibilitaría conseguir sus objetivos geopolíticos.

La situación descripta resalta la conducta dual de la OTAN, pues por un lado, no dudó, en apartarse de la normativa establecida por la ONU, para el uso de la fuerza armada, que debe ser autorizada por mandato expreso del Consejo de Seguridad. Por otro lado, utilizó al DIP, para justificar su intervención armada y la violación de su tratado constitutivo.

La Secretaria de Estado, de Estados Unidos, Madeleine Albright, manifestó que la OTAN debía comprometerse, no tan sólo en las cuestiones de defensa colectiva de carácter territorial, sino también en la defensa de los "intereses y valores compartidos". De ahí la importancia que tienen los derechos humanos en la nueva doctrina estratégica, entendidos como valores compartidos, que facilitan la legitimidad internacional para futuras intervenciones de las potencias polares.

El tratado de la Alianza Atlántica, en su Artículo 3, establece la "capacidad colectiva de resistir un ataque armado" y, en el Artículo 5, afirma su "capacidad defensiva colectiva", la argumentación tiende a legitimar una modificación a lo estipulado por los artículos mencionados, aunque se basó principalmente, en el Artículo 51 de la Carta que le consagra el derecho a repeler cualquier agresión y a ejercer el derecho de la autodefensa.

Sin embargo, las circunstancias previstas en el Artículo 51 de la Carta no se corresponden con la acción armada ordenada por Milosevic, ya que no tuvo como objetivo atacar a ningún Estado integrante de la Alianza así como tampoco amenazó o atacó a ningún país de la región. Sino que atacó una parte de una provincia de la RFY, es decir que el conflicto se inició como una crisis intra-estatal.

\section{Críticas a la interdependencia desde el neorrealismo.}

El realismo estructural postula que los seguidores de la interdependencia y los transnacionalistas se identifican con la versión económica de la teoría del dominó, donde se establece que:

\section{"cualquier cosa que pase en cualquier parte del mundo puede dañarnos directamente o por repercusión, y, por lo tanto, debemos reaccionar ante cualquier hecho..." ${ }^{37}$}

La actitud de los europeos, de tratar de solucionar las crisis de Bosnia y Kosovo por sí solos, se evidencia en el estudio efectuado por analistas internacionales, de nacionalidad norteamericana, especializados en los Balcanes. Tal es el caso del ex diplomático estadounidense, Richard Holbrooke, que considera que la prolongación de la crisis en los Balcanes, se debió a la "errónea creencia de los europeos de que podrían gestionar por sí mismos el primer reto de la posguerra fría". 38

En su libro "Para acabar una Guerra" afirma que la Unión Europea, en su proceso de toma de decisiones, pone de manifiesto la ausencia de una política exterior y de seguridad en común.

El efecto dominó, al que también hace referencia la teoría de la interdependencia en opinión del realismo estructural, tendría validez si las naciones políticamente importantes estuvieran en estrecho vinculo; hecho que quedara demostrado que en la guerra de Kosovo no ocurrió, puesto que existe una discrepancia entre la homogeneidad sugerida por la interdependencia y la diversidad de la realidad internacional.

El neorrealismo entiende que un mundo compuesto por unidades muy desiguales no puede denominarse interdependiente, en otras palabras en un contexto internacional, en el que un

\footnotetext{
${ }^{36}$ Carta de las Naciones Unidas (1945) Artículo 24-1.

${ }^{37}$ Waltz Kenneth, op. cit. pág. 235

${ }^{38}$ Holbrooke Richard (1999) "Para acabar una Gu erra”. Madrid: Biblioteca Nueva, pág. 13.
} 
reducido número de actores poseen la capacidad de defenderse a sí mismos y en el que la generalidad de los países no tienen las posibilidades de hacerlo, no puede clasificarse de interdependiente.

Teniendo en cuenta que la Unión Europea fue incapaz de resolver por sí sola un conflicto de origen esencialmente europeo, es posible afirmar la insuficiencia de la perspectiva de la interdependencia, para explicar la participación norteamericana en la guerra de Kosovo.

La participación estadounidense no puede comprenderse siguiendo los preceptos de la teoría de la interdependencia, ya que la estrategia de la intervención de la OTAN obedeció a los lineamientos y dirección de Estados Unidos con la complacencia aceptada o resignada de los países miembros de la Unión Europea.

La Casa Blanca puede justificar sus acciones en el exterior de diferentes formas, incluso exagerando la amenaza de los nacionalismos y fundamentalismos pues ello le permitiría hasta reaccionar de forma excesiva.

Según los postulados del realismo estructural, la teoría del dominó es necesaria si se desea ofrecer una justificación racional, en términos de seguridad, para acciones militares periféricas.

Otra forma de justificar la intervención en el exterior puede realizarse con el pretexto de ayudar al otro pueblo. El fundamento radicará en estos casos en que, las potencias polares, se ven obligadas a cumplir con una "obligación moral" que las hace acudir en auxilio de otros países más débiles. Además de demostrar la veracidad del compromiso con los valores que protegen las potencias líderes, que posibilitarían la construcción de un mundo mejor.

Estados Unidos, a pesar de ser la única potencia con alcance global, no puede"reordenar"el sistema internacional por sí solo, para esa tarea deben lograr el apoyo de las otras potencias polares, sobre todo de los principales miembros de la Alianza Atlántica, sólo así consolidaría su liderazgo mundial.

A través de dicha alianza los Estados Unidos pueden ejercer una disuasión poderosa con la intención de evitar futuras crisis. Para lograr un consenso internacional, la Casa Blanca y sus principales aliados, elaboran un discurso legitimador como el de la defensa de los Derechos Humanos Universales y la Libertad Comercial. Así, dan lugar, según la teoría de la interdependencia, a un mundo más pacífico y sin coerción.

La guerra de Kosovo fue útil a los intereses Estados Unidos, ya que permitió convalidar su liderazgo internacional, aunque está muy lejos de querer una verdadera interdependencia global. Porque si ésta fuese su meta, hubiese basado su intervención humanitaria en Kosovo a través de las Naciones Unidas, específicamente, con la autorización del Consejo de Seguridad.

Motivo por el cual es importante recordar las manifestaciones del secretario general de las Naciones Unidas, Kofi Annan, quien en ocasión de celebrarse la Cumbre del Milenio, hizo referencia acerca de no renunciar al derecho a la intervención humanitaria, pero siempre bajo los auspicios del Consejo de Seguridad. Este es, precisamente, el argumento que utilizaron muchos opositores a la intervención armada de la OTAN en Kosovo.

Estados Unidos, junto a los principales miembros de la OTAN, a causa de la iniciativa de intervenir en Kosovo fuera del marco legal de las Naciones Unidas, puso en evidencia la debilidad de la ONU para ejercer una efectiva autoridad internacional. Aunque en teoría, son ellas las potencias polares encargadas de proteger y estimular la vigencia institucional de la ONU.

El presidente serbio, Milosevic, comenzó la guerra, argumentando que los albaneses de Kosovo habían decidido declarar su independencia y formar un Estado paralelo. El surgimiento del ELK y la determinación de obtener la independencia, fueron los responsables de la escalada de la violencia en 1998.

\section{Justificación de la intervención armada y su inconsistencia}

Estados Unidos legitimó su intervención en razones humanitarias, dado que la limpieza étnica llevada a cabo por las fuerzas serbias sobre los albanos kosovares, era un crimen de lesa humanidad que no podía tolerarse. Pero esta justificación, era inconsistente. Ello se evidencia con la pregunta: 


\section{¿ Por qué es aceptable una intervención humanitaria en Kosovo y no una operación similar en apoyo a la minoría Kurda que estaba sufriendo la agresión y violencia de uno de los miembros integrantes de la Alianza Atlántica, como es el caso de Turquía?}

Sin embargo, si se trata de encontrar una explicación desde la perspectiva de la teoría neorrealista se puede apreciar su lógica, ya que, Estados Unidos para poder llevar adelante su geoestrategia, no podía descuidar las características de la estructura internacional. Pues en los planes geopolíticos de la Casa Blanca, Turquía, es muy importante a causa de su proximidad con las fronteras rusas y con la región de Medio Oriente e Irán. Esta relevancia geopolítica de Turquía, se evidenció en las presiones de los norteamericanos para que la Unión Europea, aprobara en 1995, una importante unión aduanera con Estambul.

Estados Unidos, con su provisión de armas y asesoramiento a los militares turcos, contribuyó al éxito de la limpieza étnica de Estambul, destruyendo casi 3500 ciudades de origen Kurdo y logrando expulsar entre dos o tres millones de personas.

Esta política de limpieza étnica emprendida por los turcos, que incluyó el asesinato de miles de personas, fue más intensiva que la realizada por el gobierno de Milosevic en Kosovo.

Sin embargo, en 1999, Turquía recibió ayuda militar norteamericana, ayuda que también recibieron aunque en menor escala Israel y Egipto. A pesar de ello, la Unión Europea y la OTAN no intervinieron para finalizar las atrocidades que sufrían los Kurdos.

Esto indica que la política de la Casa Blanca y de los principales miembros de la Alianza Atlántica es permisiva y hasta sostiene violaciones a los Derechos Humanos cuando es en apoyo a sus intereses vitales.

En esta línea de razonamiento, es evidente la contradicción y el doble mensaje de las potencias polares, no sólo en su discurso sino también en su conducta internacional, todo depende de la importancia e interés geopolítico del país en cuestión.

Uno de los postulados del realismo estructural, consiste en considerar que, en un dominio formalmente organizado, se beneficia a cada unidad que logra especializarse con el propósito de aumentar su valor, dentro de un sistema donde existe la división del trabajo.

En tal sentido, es común escuchar a muchos políticos y economistas que se lamentan porque los recursos de los Estados se destinan a sectores improductivos como son su propia defensa, en detrimento de una mejor calidad de vida de estos pueblos.

La participación de Estados Unidos, en el conflicto con perspectivas ilimitadas de posibles complicaciones, no tiene correlación con las premisas de la interdependencia. Basta como muestra que la mayor parte de los inversores y de los ciudadanos estadounidenses se oponen a iniciar "aventuras" militares en el extranjero. Aunque, de todas maneras, podría considerase que existe en los políticos norteamericanos la idea de especializar internacionalmente a Estados Unidos en el eje estratégico - militar. La que se halla avalada por el lobby del complejo económico-tecnológico que fomenta el complejo industrial militar.

Suponiendo que ese fuera el caso, Estados Unidos se convertiría en el líder mundial indiscutido o, por el contrario, en el "matón global". Pero como se vio en el análisis de la estructura interna desde la perspectiva del neorrealismo, el menos indicado es Estados Unidos. Y ello se debe a la estructura organizativa de su sistema político, muy vulnerable a los grupos de intereses y a la opinión pública. El riesgo que involucra asumir el rol internacional, en lo que respecta a la supuesta cantidad de bajas que debería afrontar el ejército norteamericano, representa un alto costo y es motivo de cautela de los decisores políticos.

La correlación de los postulados neorrealistas con la conducta del gobierno norteamericano en la guerra de Kosovo es evidente en la relación que existió, entre la política interna y externa, durante el desarrollo del conflicto, por que, al considerar las ventajas de los efectos de la guerra sobre la implementación de la política presidencial, puede verse que permitió al presidente Clinton, cambiar el foco de atención sobre cuestiones alarmantes que estaban presionando su administración.

Dicho de otra manera, el aumento de la delincuencia, los costos de la ampliación de la OTAN y el gasto del mantenimiento de efectivos militares en el extranjero, son cuestiones que pudieron haber afectado el saldo positivo de la Balanza comercial, además, del presupuesto 
que posibilitó a la política del presidente Clinton subsanar el problema de los fondos de jubilación en el área de seguridad social. Entonces, nos cabe preguntarnos

\section{¿La seguridad de los Estados-nación puede ser totalmente interdependiente?}

Porque uno de los postulados del realismo estructural establece que en un dominio desorganizado el incentivo de cada unidad es el logro de una capacidad que asegure la autoprotección, ya que no se puede contar con la ayuda de otro, tal como afirmara K. Waltz el imperativo internacional es "cuídese a sí mismo", premisa que se opone a los principios de la interdependencia.

Durante la guerra de Kosovo la insistencia de Estados Unidos provocó que Rusia no desempeñara un papel más significativo. A pesar de que los funcionarios rusos llevaran a cabo los contactos diplomáticos antes y durante la conferencia de Rambouillet.

La concepción estratégica de que las operaciones aéreas serían suficientes, inclusive sin el apoyo de Rusia para derrotar a Serbia, fue impuesta a los aliados menores de la Alianza Atlántica por Estados Unidos.

Sin embargo, los estrategas norteamericanos tuvieron presente la estructura interna e internacional durante todo el conflicto, lo que los llevó a pensar que la mejor manera, para llevar adelante su geoestrategia, era restarle importancia a la geopolítica moscovita y rodear, a la vez, a Rusia de bases militares, de Estados influenciados y protectorados por la OTAN.

La exclusión manifiesta de Rusia de esta crisis, a excepción del papel negociador directo con Milosevic, representó un cambio respecto al lineamiento proclamado anteriormente. Javier Solana, secretario general de la OTAN, en su discurso del 23 de junio de 1998, manifestó, que era esencial que "Rusia estuviera a bordo si Occidente tenía que enfrentar la grave situación en Kosovo" 39 .

Ocasión en la que fuera de suma importancia que la dirigencia moscovita participara. En otras palabras, para el secretario de la OTAN, la participación rusa permitiría lograr un consenso, caso contrario, es decir, la exclusión supondría una ofensa estratégica colosal.

El realismo estructural considera que ningún Estado acepta voluntariamente una situación de alta dependencia, porque en un sistema de auto-ayuda, "la consideración de la seguridad subordina los beneficios económicos al interés político" $" 40$

El 24 de mayo de 1999, el presidente Clinton declaró, en el New York Times, que Estados Unidos estaba decidido a terminar con las violaciones a los Derechos Humanos que el gobierno de Milosevic estaba llevando a cabo. Pero, también, realizó un reconocimiento indirecto a las críticas sobre la estrategia adoptada.

El presidente Clinton después de confirmar que la fuerza de seguridad en Kosovo debía "tener un mando de la OTAN, con medidas especiales para los países no pertenecientes a la OTAN, al igual que nuestra fuerza en Bosnia", agregaba, "Nuestra campaña militar continuará hasta que se cumplan estas condiciones, no porque seamos obstinados 0 arbitrarios sino porque son las únicas condiciones bajo las que los refugiados podrán retornar a salvo y el ELK tendrá incentivos para desarmarse: se trata de los requisitos mínimos para que la resolución se haga efectiva".

Estas afirmaciones, sobre la efectividad de la estrategia de la OTAN realizadas por Clinton, reflejaban que la participación de Estados Unidos, en Bosnia y Somalia, no se correspondía con la realidad.

Una gran cantidad de refugiados no solo no regresó a Bosnia ni a Somalia, sino que las fuerzas desplegadas, bajo el mando de Estados Unidos, no fueron efectivas para remediar la situación. A pesar de ello el presidente Clinton decía:

\footnotetext{
“...esta estrategia nos proporciona la mejor oportunidad de cumplir nuestros objetivos, para fortalecer, en vez de debilitar, nuestro interés fundamental en una relación a largo plazo con Rusia. En la actualidad, Rusia está colaborando para lograr que Belgrado acepte nuestras
}

\footnotetext{
${ }^{39}$ Tariq Ali, Springtime for Nato, NLR, 234, marzo-abril de 1999

${ }^{40}$ Waltz K. Op. cit, pág. 158
} 
condiciones. Las tropas rusas deberían participar en la fuerza que mantendrá la paz en Kosovo, transformando una fuente de tensión en una oportunidad para la cooperación, tal y como sucedió con nuestros esfuerzos conjuntos en Bosnia..."11

Este cambio de postura, respecto de la participación restringida de la diplomacia moscovita conforme a los parámetros establecidos por la Alianza Atlántica, evidenciaba la relativa dependencia del gobierno de Yeltsin a la Casa Blanca así como mostraba su decisión de restar el respaldo a su canciller Primakov.

La dependencia económica de Rusia hacia Estados Unidos y la Unión Europea, evidencia una correlación, aunque relativa, con los postulados de la Interdependencia. Esta relatividad está dada por el acatamiento a los lineamientos de la OTAN, obediencia, que no se materializó con el desarme convencional y no convencional, tema que no trataremos aquí.

En un artículo de la primera plana del Herald Tribune (24-3-99) se informó que el acuerdo para el desarme START-2 se había estancado porque la Duma (Parlamento Ruso) no estaba dispuesta a aprobarla. Circunstancia que se corresponde con la premisa neorrealista, que dice que, " en un mundo desorganizado, el incentivo de cada unidad es el de ponerse en la situación de cuidarse a sí misma, ya que no se puede esperar que alguien más lo haga" ${ }^{2}$

En consecuencia el comportamiento de las potencias, que intervinieron en la guerra, se relaciona con el hecho que los países no buscan situaciones de gran dependencia; pues en un sistema de auto-ayuda, la seguridad subordina los beneficios económicos al interés político, tal como lo afirma el realismo estructural y como de hecho quedó demostrado durante el conflicto.

\section{Insuficiencia de la interdependencia}

Luego de finalizado el sistema bipolar, Estados Unidos y sus aliados europeos, manifestaron que la globalización profundizó la interdependencia. La cual posee asimetrías que beneficiaron, en especial, a las potencias polares.

La teoría de la interdependencia sostiene que la expansión de los valores democráticos y de la libertad económica se promoverá con mayor eficacia a través de la creación de instituciones internacionales. Estos, a su vez, ayudarían a dominar las conductas mezquinas de los Estados y los alentarían a descubrir las ganancias inmediatas de la cooperación.

Sin embargo, como sostiene el realismo estructural, los Estados se preocupan más por la posible división de ganancias, de decir, por los beneficios que pueden fortalecer más a otros que a sí mismos. También sostiene que un Estado procura no convertirse en dependiente por medio de empresas cooperativas y del intercambio de bienes y servicios. Estas preocupaciones son dos maneras con que, la estructura de la política internacional, limita la cooperación entre los Estados ${ }^{43}$.

Un mundo interdependiente exige unidad de criterio, considerando que hay ciertas conductas que no pueden llevarse a cabo si los Estados no la siguen, y los Estados no pueden seguirlas si no están seguros de que los otros también lo harán. De esto surge que Estados Unidos hablara del nuevo orden mundial.

La interdependencia necesita de un conjunto de reglas, las que se basan en la defensa y cumplimiento de normas jurídicas, como lo son, por ejemplo, los Derechos Humanos Universales. Pero su falta de cumplimiento nos demuestra la insuficiencia de sus postulados, para explicar la conducta de Estados Unidos en la guerra de Kosovo.

$\mathrm{Si}$ queremos reflexionar sobre los valores que rigen a la sociedad, tanto norteamericana como de la Unión Europea, y sobre la forma en que se ejerce el poder en ellas, debemos interpretar su concepción jurídica.

Con el estudio del poder y su desarrollo en Occidente, comprobamos que su crecimiento se produjo en gran medida, a su amparo en las instituciones jurídicas y judiciales. Es decir que,

\footnotetext{
${ }^{41}$ BLACKBURN R. Op. cit, pág. 146

${ }^{42}$ Waltz K. Op. cit, pág. 158

${ }^{43}$ Waltz K. Ibídem, pág. 157
} 
con el desarrollo de estas instituciones, se logró reemplazar la antigua solución de litigios privados, mediante la guerra civil, por un procedimiento de arreglo en tribunales, con leyes que le otorgaban al Estado la posibilidad de solucionar él mismo las controversias.

Del mismo modo, el Derecho Internacional, fue manipulado por Estados Unidos y demás potencias polares occidentales, tal como quedó demostrado en la guerra de Kosovo, para asegurar su supremacía internacional definió las formas y los mecanismos de su propio poder, a costa de la libertad y soberanía de otros Estados.

En otras palabras, la supremacía norteamericana y de la Unión Europea se halló garantizada por el desarrollo de un pensamiento jurídico universal.

Estados Unidos fundamentó y legitimó su intervención en la Defensa de los Derechos Humanos Universales, lo que, al mismo tiempo, benefició a los grupos económicos y empresariales, pues el incremento del poder estatal norteamericano a costa de la disminución de las capacidades de otros Estados les produjo ganancias.

Las empresas norteamericanas tuvieron un alto interés en desarrollar ese sistema de derecho global, porque le permitía dar forma a las transacciones económicas fundamentando y garantizando su propio desarrollo económico social.

El modo en que fuera manipulado el derecho internacional, tanto por los funcionarios norteamericanos como por los principales miembros de la Alianza Atlántica durante el conflicto, demuestra cómo el derecho se transformó en un sistema de representación social del poder funcional a las potencias polares.

Las propuestas del Grupo de Contacto internacional para el futuro de Kosovo, estudiadas en las conversaciones de París/Rambouillet en febrero de 1999, propiciaban la formación de una misión de supervisación internacional en Kosovo. Ellas se basaban en las resoluciones de Paz de Dayton.

En Dayton se acordó una separación de poderes, entre la implementación militar del tratado de paz a cargo del mando de la OTAN y la aplicación civil, bajo la responsabilidad de un alto representante internacional, al que se llegaría por medio de elecciones, control mediático quedaría bajo el mando de la Organización para la Seguridad y la Cooperación en Europa (OSCE).

En esa ocasión se previó una misión por el lapso de tiempo de un año, tanto los poderes civiles del alto representante como para la OSCE, en cambio, los planes para Kosovo establecieron, supuestamente, para un período de tres años, pero no estipularon fechas fijas para su implementación.

El cambio que tuvo lugar en Rambouillet, sobre los poderes limitados de una administración de transición al de un protectorado internacional, evidencian la dinámica entre la implicación norteamericana y la Alianza en los Balcanes. Esta situación refleja que los efectivos de la OTAN, funcionarios y administradores internacionales son más indispensables para alcanzar la estabilidad en los Balcanes; lo que equivale a decir que la población nativa empezaba a desempeñar un rol de menor importancia en las decisiones sobre su propio futuro.

El acuerdo de Rambouillet fue impuesto por Estados Unidos junto con los miembros del Grupo de Contacto internacional, de los países con mayores intereses en la temática de los Balcanes como Gran Bretaña, Alemania, Francia, Italia y Rusia y; por el Consejo de Aplicación de la Paz. Estos últimos cooperaron en su diagramación y luego lo describieron como un paso adelante hacia la soberanía y la autonomía.

La diplomacia norteamericana al igual que la de Europa Occidental tuvo la libertad de convalidar sus mandatos en Bosnia, porque los acuerdos de Dayton como los de Rambouillet, comprometían sólo a las fuerzas y partidos balcánicos, y a las organizaciones internacionales únicamente se responsabilizarían de la implementación.

En las reuniones internacionales ad hoc, efectuadas por el Grupo de Contacto internacional, se organizó la política a implementar en programas. Posteriormente participaron también las instituciones internacionales, como la ONU, la OTAN, la OSCE, la Unión Europea (UE), el FMI y el Banco Mundial, para que también ellos elaboren sus propios programas. 
Sin embargo ninguno de estos foros ad hoc $u$ organismos internacionales se comprometieron por cláusula en cumplir con el acuerdo de Bosnia o Kosovo ${ }^{44}$.

En teoría, el control de las Organizaciones Internacionales tendrían que estimular y favorecer el desarrollo de la práctica democrática para facilitar la transición hacia un gobierno autónomo y representativo. Sin embargo, la realidad en Bosnia como en Kosovo demuestra lo contrario. En lugar de fortalecer las instituciones democráticas en estos lugares así como en Serbia incentivando el compromiso y la negociación, la Administración Internacional perjudicó la política en instituciones bosnias, kosovares y serbias. Como consecuencia el odio étnico se robusteció aún más.

El rol, en expansión, de las diferentes Organizaciones Internacionales fue reduciendo, cada vez más, la capacidad de debatir, implementar y decidir sobre temas de intereses vitales de los pueblos de los Balcanes.

El acuerdo alcanzado en Dayton incluía la descentralización del poder político y la creación de administraciones multiétnicas en Bosnia, para unificar a las instituciones del Estado, dar seguridad a las minorías étnicas y proteger la autonomía. Todos sabemos que ello no ocurrió.

Las negociaciones de Rambouillet también establecieron la descentralización, la defensa de las comunidades nacionales y los poderes de las autoridades comunales locales; sin embargo, teniendo presente la experiencia de Dayton, cabían dudas sobre el cumplimiento de lo prometido.

Robin Blackburn afirma:

“La promesa de protección de las minorías, hecha en Dayton a los tres pueblos integrantes, no se ha cumplido bajo la administración internacional. En los diversos ámbitos del Estado, de las entidades federadas, de las ciudades y de los municipios, se ha hecho patente un claro modelo, según el cual apenas se otorga control a las mayorías electas sobre el diseño político. Sin embargo, el poder no se ha descentralizado para ofrecer a los grupos minoritarios seguridad e interés por las tareas de gobierno, sino que más bien se han transferido a las instituciones internacionales y recentralizado en las manos del alto representante..." 45

Lo que pone de manifiesto que la supuesta interdependencia, afianzada en los valores democráticos y la libertad económica, que favorecerían un mundo pacífico, en realidad incentiva democracias vacías, impuestas artificialmente por la comunidad internacional y para que dependiera de ella.

En opinión de John Pilger, analista internacional, la solución para Kosovo, impuesta en Rambouillet, es que los albanos kosovares sólo recibirán una falsa autonomía con menos libertad de la que tenían bajo la antigua Constitución yugoslava ${ }^{46}$

Estas limitaciones, al desarrollo de una sana democracia, se contraponen con los postulados de la teoría de la interdependencia. A su vez, esta situación, perjudica a los serbios, porque los acuerdos logrados en Rambouillet debilitan la influencia serbia sobre Kosovo y, también, afectan a la soberanía serbia y a la yugoslava.

En tal sentido, el Apéndice B dice de qué concede a los efectivos de la OTAN "el libre tránsito sin ningún tipo de restricciones y el acceso sin obstáculos por toda la República Federal Yugoslava", además de que "se garantiza a la OTAN el uso de aeropuertos, carreteras, vías ferroviarias y puertos sin el pago de cuotas, aranceles, derechos, peajes o tasas", por otra parte, los efectivos de la OTAN tienen inmunidad ante posibles acusaciones por delitos civiles o penales ${ }^{47}$.

\footnotetext{
${ }^{44}$ Szasz P. "Current Developments: The Protection of Human Rights Through The Dayton/Paris Peace

Agreement on Bosnia”, Aemrican Jorunal of International Law, Vol. 90. 1996, pág. 304.

45 Ibídem. Pág. 161

${ }^{46}$ Pilger J. "War in Europe", New Statesman, 2 de abril de 1999.

47 Appendix B: Status of Multi-National Military Implementation Force. Interim Agreement for Peace and Self-Government in Kosovo.
} 


\section{Capítulo V La explicación neorrealista}

\section{Opciones fundamentales y amenazas potenciales}

Si Kosovo, en teoría, no representaba amenaza a Estados Unidos:

\section{¿Por qué debía intervenir en este conflicto?}

El principal objetivo en este punto es hallar una respuesta que satisfaga las expectativas, por ello comenzaré a responder invirtiendo el interrogante:

\section{¿Qué peligros representaba la inacción de los Estados Unidos?}

El presidente Clinton, en un mensaje pronunciado en Los Ángeles, dijo que se empeñaría en hacer que Estados Unidos fuera "el catalizador de una reacción mundial contra la agresión". "En un mundo de cambios", dijo, "la seguridad emana de la iniciativa, no de la inercia". Nada de lo dicho tuvo demasiado efecto sobre los votantes norteamericanos, que estaban más interesados en las propuestas económicas de los demócratas, sin embargo, en Europa causó un impacto profundo.

La Administración Clinton sabía que, en el caso de no involucrarse en la guerra de Kosovo, se exponía a que las relaciones de Estados Unidos y la Unión Europea se resintieran y comenzase un proceso de debilitamiento que podía repercutir en la solidez de la OTAN, esta situación que tendría el efecto de agravar la tensión existente entre Grecia y Turquía, lo que, a su vez, provocaría una respuesta Rusa.

Otro tema importante a considerar fue la presencia, y crecimiento de influencia en la región, de musulmanes radicales apoyados logísticamente por Irán, similar a lo ocurrido durante la Guerra de Bosnia.

Existen pruebas sobre la acción de grupos de mujahidines (luchadores por la libertad) que operaban apoyando al ELK, un peligro latente y real, que residía en que los fundamentalistas radicales del Medio Oriente, sumaran para sí a los musulmanes seculares de la región para ser más fuertes.

Ello no sucedió, pero si se hubiera dado no sólo hubiera puesto en peligro la fágil estabilidad alcanzada en Bosnia-Herzegovina, sino que también, hubiera acercado a las puertas de Europa Occidental al fundamentalismo islámico.

El resquebrajamiento del acuerdo de paz alcanzado en Dayton, debido a un aumento del poderío bélico de los musulmanes en la región, podía romper el equilibrio entre los croatas, eslovenos, serbios, macedonios y griegos. Por ello la OTAN se negaba a armar al ELK con armamento pesado.

No obstante la no-injerencia de Norteamérica, hubiese perjudicado su propia geoestrategia en relación con su necesidad de ampliar a la OTAN, de promover una política común junto con los europeos hacia Rusia, Oriente Próximo e Irán, el terrorismo, los Derechos Humanos, el crimen organizado y el Medio Ambiente.

La supremacía global norteamericana según el realismo estructural

Según la historia de las intervenciones armadas de Norteamérica en el exterior, a partir de la Segunda Guerra Mundial actuaron en regiones distantes y en hechos que podrían alterar sólo la situación de los países próximos. 


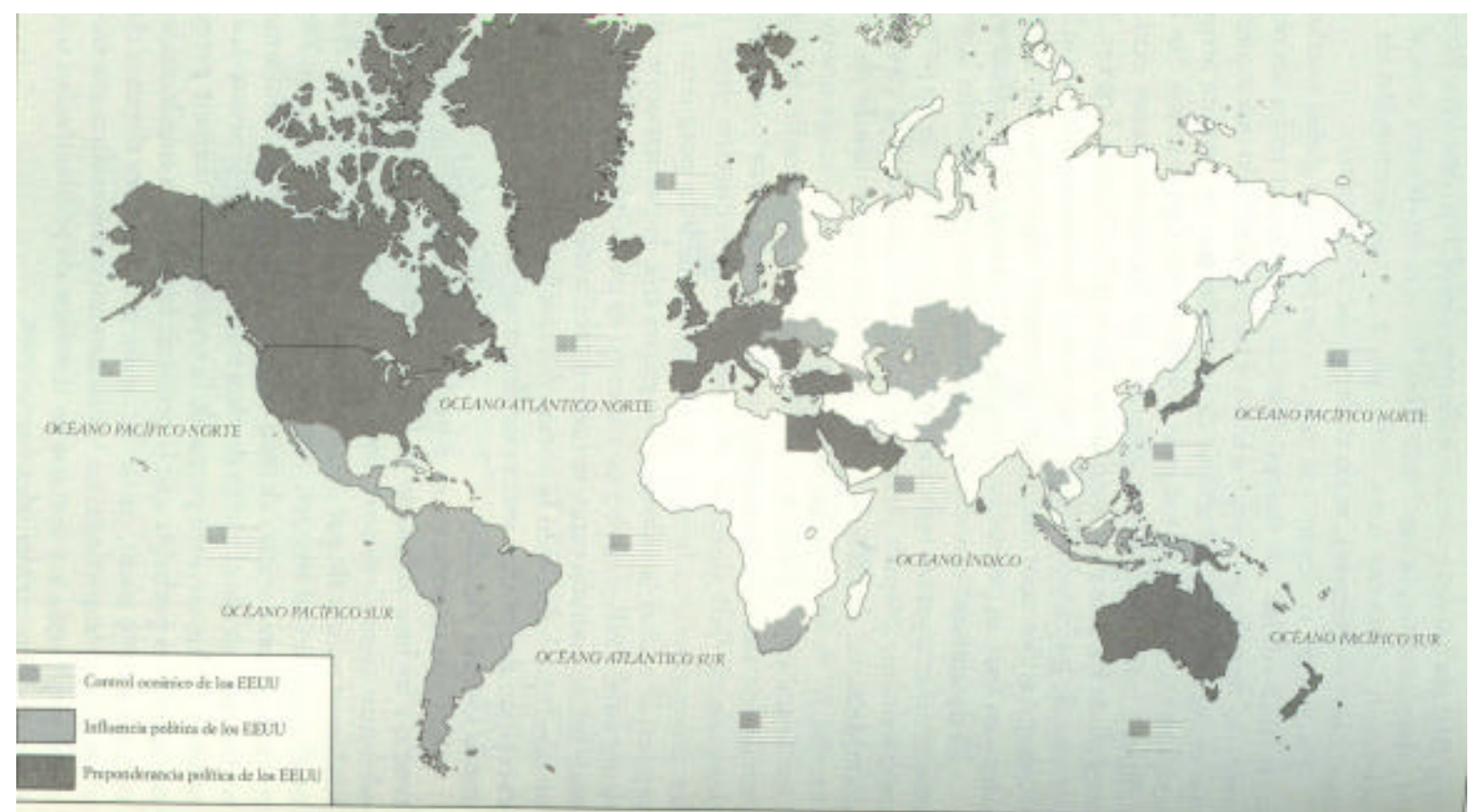

Fuente: Zbigniew Brzezinski, “El gran tablero mundial”

Para el caso en que los encargados de la política exterior, deban decidir realizar intervenciones en el extranjero, donde se encuentre en riesgo su supremacía global (ver mapa), el realismo estructural plantea el siguiente interrogante:

\section{¿Qué es peor: el error de cálculo o el exceso de reacción?}

Este dilema es el que se le presentó a los asesores del presidente Clinton, quienes se decidieron por la intervención, pues consideraron los factores históricos; como lo especificó la Secretaria de Estado, Madeleine Albright, cuando señaló que las democracias no debían ser indiferentes ante los crímenes en Kosovo.

La Secretaría de Estado fundamentó que su decisión estaba basada en el error que incurrieron las democracias en Munich(1939), puesto que permitieron que una crisis limitada saliera de control, a causa de la pasividad e indecisión de las democracias occidentales.

Los analistas norteamericanos se convencieron de que la experiencia de Munich reflejaba el precio que, tarde o temprano, las democracias pagaron por dejarse presionar y chantajear por gobiernos autoritarios.

Cuando se adoptó la política de concesión, ante un Estado belicoso y expansionista como fue el Estado alemán bajo el régimen nazi, las democracias se comprometieron a una política de apaciguamiento, con la esperanza de que el líder nazi pusiera fin a su política de fuerza al lograr que todos los de origen alemán volvieran a su patria.

El 24 de abril de 1987 en Prístina, capital de Kosovo, Milosevic decía: “Nadie se atreverá a golpearlos nuevamente" sus manifestaciones eran recibidas con entusiasmo por un público serbio exaltado, puesto que eran objeto de discriminaciones por parte de la mayoría albanesa.

Las manifestaciones de Milosevic estaban en contra del principio establecido y defendido por el mariscal Tito de "hermandad y unidad", que había sido seguido en toda Yugoslavia durante el período comprendido entre 1945 y 1980; en ese tiempo no se discutía sobre asuntos étnicos en la vía pública, ya que toda manifestación en público estaba prohibida, pues ello podía incentivar las divisiones sociales. Pero, con Milosevic este tipo de manifestaciones era permitido, porque con ello incentivaba el rencor étnico de los serbios hacia los albaneses en Kosovo, lo que le permitiría ser visto como el defensor de esa cultura. Pues allí se encuentran las iglesias, monasterios y símbolos de la cultura serbia.

La coalición conformada por el partido de Izquierda Yugoslava, el Partido Socialista de Milosevic, y por el Partido Radical del ultra nacionalista Vojislav Seselj aseguró no sólo el 
triunfo de Milosevic sino su permanencia en el poder, tan necesarios para llevar adelante el proyecto de construcción de la Gran Serbia, porque Kosovo no sólo es una provincia fértil y rica en minerales, sino también un objetivo geopolítico europeo siempre presente en los estrategas norteamericanos. Es importante recordar que Yugoslavia, con su comunismo flexible, oscilaba sus simpatías políticas tanto con Occidente como con la Unión Soviética.

Sin embargo, nunca permitió que ninguna potencia occidental ejerciera su influencia sobre ella, negativa que se materializaba en el constante rechazo de Yugoslavia de formar parte de la OTAN.

Milosevic reafirmó su promesa de campaña, luego de las elecciones y se dirige a Kosovo, para manifestar que usaría la fuerza y las armas, con el propósito de revertir la injusta situación de los serbios en la provincia.

En febrero de 1999, Milosevic comenzó a actuar contra la población étnica albanesa, agravando el contexto regional para los europeos y norteamericanos. La supuesta despreocupación europea y estadounidense sobre la provincia serbia se debía a que, luego del acuerdo alcanzado por el diplomático estadounidense Richard Holbrooke para la guerra en Bosnia, estos países, trataban de evitar todo intento de desestabilización de los Balcanes.

Esa premisa que dejaron de lado, cuando la comunidad internacional debió enfrentarse con la necesidad de responder a la crisis humanitaria que se desencadenó y que amenazaba con propagarse. Los aliados de la OTAN decidieron solucionar la crisis de manera política y efectuar una presión, sustentada en la amenaza del uso de la fuerza, para la búsqueda de un acuerdo entre las partes.

No obstante, un acuerdo, entre los serbios y los líderes independentistas, se iba tornando cada vez más difícil, ya que el odio y la venganza se profundizaban cada vez más en ambos bandos. Pero la matanza del 15 de enero de 1999, en la aldea de Rack alejó toda esperanza de acuerdo entre los beligerantes.

En general, la población albanesa sólo aceptaba para la solución del conflicto un retiro total de las fuerzas serbias de Kosovo. Asimismo Milosevic, tampoco estaba dispuesto a permitir una solución de compromiso. A la Unión Europea y, en especial, a Estados Unidos se le planteó el dilema sobre cómo intervenir en un conflicto armado interno y, con qué objetivo.

El agravamiento del conflicto, la violación de Milosevic al acuerdo de octubre, pactado con Richard Hobrooke, y la inutilidad evidente de las presiones de los aliados europeos, determinó que Estados Unidos cambiara su política de apaciguamiento.

Con la determinación de neutralizar la violencia y evitar una propagación del conflicto en la región, la Administración Clinton optó por señalar al presidente Milosevic como culpable de la violencia.

El error de la diplomacia norteamericana fue no comprender que era casi imposible obtener un compromiso de Milosevic, como el que si se había alcanzado en Dayton, porque la sola idea de un Kosovo autónomo dentro de Serbia, que continuara aumentando la densidad de población albanesa, no podía ser aceptada por Belgrado.

El ajuste estratégico de los Estados Unidos

Cuando el presidente Clinton se refirió a los conflictos de origen intraestatal manifestó:

"Los conflictos locales tienen consecuencias mundiales. El propósito de la pacificación, ya sea mediante la diplomacia o la fuerza, debe ser resolver conflictos antes de que aumenten y perjudiquen nuestros intereses vitales..." ${ }^{48}$

La imposibilidad de Washington de seguir presionando a Milosevic para que cooperara con la estabilidad en los Balcanes, se visualizó más a partir de la masacre en Racak y de la manifiesta negativa del ELK de renunciar a la resistencia armada, y determinó que los norteamericanos cambiaran de estrategia.

\footnotetext{
${ }^{48}$ Clinton William Jefferson "POLÍTICA EXTERIOR PARA LA ERA GLOBAL". Casa Blanca. Secretaría de Prensa. Omaha, Nebraska 08-12-00. Pág. 3
} 
Según el neorrealismo un país con desorden interno y con falta de coherencia, carece de gobernabilidad, y ningún cuerpo extranjero, por grande que sea su fuerza militar, puede ejercerla. Si el problema es la insurrección, no puede esperarse que ningún ejército extranjero pacifique al país que es incapaz de gobernarse ${ }^{49}$.

La geopolítica norteamericana demostró de manera consistente, aunque con disimulo para no perjudicar su relación con Moscú, que se propiciaba el crecimiento de la influencia estadounidense sobre regiones del espacio europeo que pudieran permitir, al menos en teoría, que la Federación Rusa aspirara a lograr el estatus de segunda potencia, en política internacional.

Esta evidencia está demostrada en el proceso de redefinición del espacio europeo, pues la consolidación de Estados nacionales nuevos se realiza a cambio de la aceptación de la influencia de Occidente, materializada en su cooperación o su inclusión a la OTAN o a la Comunidad Europea.

Teniendo presente tanto la necesidad norteamericana de establecer una presencia militar efectiva en la región de los Balcanes -declaraciones del ex embajador Robert E.Hunter (ver página 10)- como la renuencia de Belgrado de permitir bases de la OTAN en suelo serbio, se hace más clara la intencionalidad geopolítica de la Casa Blanca luego de la supuesta intervención humanitaria.

Desde el principio del conflicto los críticos de la intervención armada de la OTAN, habían manifestado que la verdadera motivación norteamericana, para intervenir en la crisis, era el establecimiento de un protectorado en Kosovo. Lo que también explicaría la estrategia militar adoptada por la OTAN en la guerra y su negativa para iniciar una invasión terrestre. Esto refleja una correlación con la premisa neorrealista puesto que considera que la fuerza militar, usada internacionalmente, es un medio de establecer control sobre un territorio, no de ejercerlo.

La intervención norteamericana, demostró, sin embargo, que buscaba ampliar su influencia y lograr un efectivo control en la región; con ello deseaba promover un orden político efectivo, es decir, alcanzar la “compelencia", término inventado por Thomas C. Schelling ${ }^{50}$.

Los Estados Unidos en Vietnam sí querían obtener la "compelencia", ya que no sólo trató de derrotar al Vietcong y al ejército norvietnamita, sino que también su intención era la de establecer un orden político competente.

La campaña aérea de la Alianza, masiva e intensa, no solamente logró debilitar la capacidad de reacción de las fuerzas militares serbias, sino también destruyó infraestructuras en toda Serbia. El acuerdo de Rambouillet, no concretó las aspiraciones de los albanos kosovares, pero consiguió a la OTAN un emplazamiento estratégico más favorable en la región.

Otro aspecto importante a tener en cuenta es el hecho de que las fuerzas militares, extranjeras o domésticas, nunca fueron efectivas para implementar la tarea de pacificación. Esta situación se complica más, si un país se encuentra dividido por el partidismo y con ciudadanos comprometidos políticamente. ${ }^{51}$

Los estrategas norteamericanos consideraron que la necesidad de intervenir surgió del peligro estratégico y moral, que se tradujo en un agravamiento del conflicto. Los civiles albaneses de kosovo hubieran huido masivamente buscando refugio en países limítrofes de Europa con economías más débiles. Y con regímenes democráticos aún no consolidados, con la consiguiente escalada de una guerra que hubiera representado la inminencia de la generalización del conflicto, y hubiese incrementado las tensiones con Rusia y China. Si ello hubiere ocurrido la Alianza habría sido desprestigiada y ridiculizada por ser incapaz de garantizar los valores que rigen a sus socios miembros y cuya defensa fomentaron su creación.

\footnotetext{
${ }^{49}$ Waltz K. Op. cit, p. 276

${ }^{50}$ Schelling Thomas, “Arms and Influence”. New Haven: Yale University Press. 1966, pp. 70-71.

${ }^{51}$ A manera de ejemplo puede mencionarse el intento frustrado de Estados Unidos al tratar de pacificar Vietnam, la infructuosa lucha de Francia en Arg elia (1830 y 1847) y la costosa guerra de los boers (1898 y 1903) emprendida por Inglaterra que contaba en esa época con la marina más poderosa del mundo.
} 
El gobierno de Milosevic estaba compuesto por xenófobos y nacionalistas, características contrarias a la expansión de la influencia norteamericana. Esta influencia se basaba en una presión indirecta sobre los sectores dependientes, y estaba propiciada, a su vez, por el atractivo que generan los principios democráticos y sus instituciones.

La dominación indirecta de Estados Unidos estaba favorecida por el manejo que poseían sobre los medios de comunicación global, la cultura de masas y por su liderazgo en tecnología de punta, como reflexiona Amin Samir, estas capacidades facilitan supremacía internacional y ayudan en el intento de lograr la persuasión cultural sobre la opinión mundial. Es por esto, que el intento de Milosevic de construir la Gran Serbia, sobre la ideología nacionalista y xenófoba generara el rechazo norteamericano y europeo, ya que las ideologías no sólo contribuyen al desarrollo de objetivos nacionales ilimitados, sino que, en ocasiones, incentiva a los Estados a plantearse metas que pueden hacer peligrar el sistema internacional ${ }^{52}$.

El crecimiento y fortalecimiento de un Estado con tales características políticas hubiera sido un mal ejemplo, además de un acontecimiento contrario a la tendencia que se venía dando en Europa del Este, puesto que la adopción de una política con supremacía civil sobre lo militar de los países ex comunistas era un prerrequisito para el ingreso a la OTAN.

La política norteamericana de propagar los valores democráticos en los estados de Europa del Este, es útil a su geoestrategia y, además, facilitan la aplicación efectiva de una hegemonía indirecta mediante la aceptación aparentemente voluntaria de los países que ingresan en la orbita de influencia de los Estados Unidos; situación que les facilita el consenso doméstico e internacional a la política exterior norteamericana, lo que es muy importante para una democracia sometida, en su concepción y ejecución, ya que está expuesta al escrutinio constante, tanto de la opinión de sus ciudadanos como de la opinión pública mundial.

La guerra en Kosovo significó para Estados Unidos, un reto al desarrollo de su hegemonía en Europa sur-oriental, porque la política del presidente Milosevic amenazaba el crecimiento de la democracia y la estabilidad regional. La defensa de los intereses nacionales estadounidenses se hallaba en juego en una región remota para la mayoría de los norteamericanos que lo consideraban como un conflicto ambiguo, que estaba originado en un Estado supuestamente soberano.

La Administración Clinton buscó la ayuda y el apoyo de los miembros del Congreso, y de la mayoría de los ciudadanos norteamericanos, para la protección de esos intereses y para asegurar los recursos del éxito de la intervención.

Nuevamente, se aprecia la relación con los principios neorrealistas en la diagramación estratégica de Clinton.

A pesar que la participación directa y unilateral, no deseada, tanto en el ámbito doméstico como en el escenario internacional de Estados Unidos, éste se pudo involucrar de manera indirecta y en forma eficaz mediante la acción de la imposición de la paz encabezada por la OTAN.

La justificación de la Casa Blanca de que sus fuerzas militares debieron intervenir para detener la limpieza étnica y la inestabilidad regional, no sólo logró la legitimación ante sus ciudadanos sino, también, ante el conjunto de la comunidad internacional y, principalmente, ante sus socios de la Alianza Atlántica. A pesar de que se manejó fuera del procedimiento vigente, establecido por la Carta de las Naciones Unidas en el Capítulo VIII.

En Kosovo no sólo la OTAN neutralizó la limpieza étnica y la inestabilidad regional, sino que también obligó la retirada de las fuerzas serbias y, además, posibilitó el despliegue de una presencia militar internacional en la zona, bajo el control y responsabilidad de la Alianza Atlántica, que da seguridad a la región.

La estrategia que la Casa Blanca implementó en el conflicto, no resolvió el problema entre los serbios y los albanos kosovares, porque tal como lo dice el neorrealismo: si un país a causa de su desorden interno y de su falta de coherencia, no es capaz de gobernarse, ninguna fuerza militar extranjera pude lograrlo.

El presidente norteamericano era consciente de la insuficiencia de la intervención armada para la solución del conflicto en Kosovo. Clinton manifestó al respecto:

\footnotetext{
${ }^{52}$ Amin Samir, (1997). "Los desafíos de la mundialización”. México. Siglo XXI.
} 


\begin{abstract}
“...debemos recordar que la revocación de la depuración étnica en Kosovo no es suficiente para acabar con los conflictos étnicos en los Balcanes y establecer una estabilidad duradera. La Unión Europea y Estados Unidos deben hacer por Europa suroriental lo que hicimos por Europa occidental después de la Segunda Guerra Mundial y por Europa central después de la guerra fría..." 53
\end{abstract}

Uno de los objetivos norteamericanos era lograr de manera indirecta, es decir, a través de la OTAN, el control sobre una región que durante el gobierno de Tito y luego de Milosevic se le había negado, aunque su intención no era gobernar la región y solucionar las causas del conflicto.

La persistencia de la amenaza de que resurja un agravamiento de la crisis entre los albanos kosovares y serbios, brindó a los estrategas estadounidenses la justificación necesaria para la presencia militarizada de la OTAN en la región; la que legitima la intromisión en asuntos internos por medio del principio de injerencia coercitiva para la defensa de las minorías afectadas por las violaciones a los derechos humanos. Como queda establecido en la ya mencionada, Resolución 1244 (1999)

\title{
Ventajas de la implementación del poder militar norteamericano
}

La teoría agustiniana de la "guerra justa" sostiene que los medios deben ser proporcionados a los fines. La decisión de comenzar una guerra debe adoptarse una vez que se ha terminado con todas las posibilidades de negociación y como consecuencia de un acto de autoridad legítima.

El presidente Clinton había justificado la presencia militar estadounidense y de la OTAN manifestando:

“...Estamos en Kosovo con nuestros aliados para apoyar a una Europa que, por primera vez a nuestro alcance sea pacífica, unida y libre. $Y$ estamos allí para ombatir la mayor amenaza que aún queda contra esa visión: la inestabilidad en los Balcanes, acrecentada por una cruel campaña de depuración étnica..." ${ }^{14}$

Los críticos sobre la estrategia implementada por los Estados Unidos argumentaron que la misma era insuficiente, porque no solamente era incapaz de solucionar la situación de los kosovares, sino que agravó el conflicto, ahondó la limpieza étnica puesto que comenzó a realizarse de manera sistemática y masiva. Circunstancia, que incentivó la idea que el poder militar estadounidense era insuficiente para resolver la crisis, ya que la guerra causaba graves prejuicios a los que supuestamente se quería defender. Y que además, impedía una efectiva negociación diplomática, porque se violó los tratados y no se respetó a los organismos internacionales encargados de tomar las decisiones.

Según la premisas neorrealistas, la afirmación sobre la no-efectividad del poder militar en la resolución de los conflictos intra-estatales, en especial, desde las perspectivas de las teorías de la interdependencia y del materialismo dialéctico es inconsistente. Aunque la perspectiva del realismo estructural se considera que es erróneo decir que los Estados militarmente fuertes son débiles solo porque no pueden imponer un orden en los Estados menores, pues ello implicaría confundir el propósito de los instrumentos y los medios del poder externo, con las agencias del gobierno interno. La incapacidad de establecer control político sobre otros no indicaría debilidad militar ${ }^{55}$.

Así mismo, otra premisa neorrealista dice que los Estados fuertes no pueden hacer todo con sus fuerzas militares, pero son capaces de hacer cosas que los Estados militarmente débiles no pueden.

\footnotetext{
${ }_{53}^{53}$ Clinton W. J. "UNA GUERRA JUSTA Y NECESARIA". The New York Times 23-05-99. Pág. 2

${ }^{54}$ Clinton W. J. Ibídem, pág. 1

${ }^{55}$ Waltz K. Op. cit., pág. 277.
} 
La realidad internacional se ha presentado cada vez más compleja, política y económicamente, en el transcurso de las últimas décadas, pero a pesar del desgaste relativo de su posición dentro de la economía global, Estados Unidos, sigue teniendo a "groso modo" una proporción mayor en la carga de seguridad estratégico-militar internacional.

Luego de la caída del comunismo, los norteamericanos se planteaban si Estados Unidos debía reducir sus compromisos de seguridad internacional y pasar una parte de la responsabilidad a sus aliados.

El surgimiento de una Europa unida requería de la participación constructiva y decidida de Estados Unidos, para evitar el error en el que incurrieron las democracias occidentales en Munich (1939) al no intervenir decididamente ante gobiernos expansionistas y xenófobos. Pero este acontecimiento requeriría de un cambio significativo en la estructura y en los procesos de la Alianza Atlántica, principal vínculo entre Estados Unidos y Europa. Porque la Alianza Atlántica no sólo brinda los medios efectivos para el ejercicio de la influencia europea, sino que a su vez posibilita una legitimación de la presencia militar estadounidense.

Lo dicho antes, significaba, en cierta manera, disminuir la hegemonía internacional norteamericana puesto que daría un mayor margen de autonomía a sus aliados, los que estarían cada vez más incentivados para actuar en forma autónoma.

El otro camino a seguir por los decisores de la política exterior norteamericana fue generar un cambio de percepción sobre la diplomacia y la fuerza militar, dos extremos opuestos del acontecer de la política nacional, a los que se recurre indistintamente cuando uno de los dos no da el resultado esperado. Lo novedoso del cambio consistió en reconocer que una de ellas sostiene a la otra.

La situación antes planteada significó, para los estrategas de la Administración Clinton, la búsqueda de un equilibrio entre los intereses de política exterior, la defensa y la consolidación de la hegemonía norteamericana a través de la instrumentación de una política exterior compatible con los valores y creencias domésticas, que posibilitara alcanzar la legitimación y confianza internacional.

Dichos objetivos fueron alcanzados indirectamente, por la Casa Blanca, a través de recursos más flexibles. Es decir, mediante, la conciliación de la política exterior y la defensa, con la seguridad internacional; en otras palabras, por medio de la intervención directa, en programas de educación y capacitación militares y, en acuerdos de seguridad multilaterales.

Todos estos esfuerzos multiplican los instrumentos que aseguran la hegemonía internacional estadounidense, y también brindan relaciones de seguridad más fuertes con los aliados y con los otros Estados, tal como quedara demostrado en el conflicto de Kosovo.

\section{Lógica norteamericana: "ni dominio ni autoexclusión"}

Estados Unidos mantiene su hegemonía, utilizando los Estados menores. Estos le sirven de propaganda y como medio para la propagación del sistema democrático cosmopolita ${ }^{56}$, además, son un medio para la universalización de los valores de la cultura occidental, porque incentivan la sensación de interdependencia e igualdad de derechos de las naciones.

Los analistas de la política internacional, en especial aquellos partidarios de la interdependencia, tienden a creer que las guerras no permiten a Estados Unidos alcanzar metas positivas mediante la aplicación de su poder militar.

Desde el neorrealismo esta creencia es vista como errónea, pues ignora los éxitos norteamericanos, obtenidos gracias a su poder, y confunden la utilidad de la fuerza con su uso.

La utilidad de la fuerza para asegurar el status quo se incrementó en la era de la globalización, constituye uno de los propósitos más importantes de las potencias polares. Pero, es necesario tener en cuenta que la utilidad de la fuerza disminuye en forma notable, si se la implementa con la intención de cambiar el sistema.

La guerra de kosovo, a los estadounidenses, les permitió, demostrar la incapacidad y debilidad que poseen los europeos para llevar a cabo operaciones militares tendientes a

\footnotetext{
${ }^{56}$ Ver Held D. (1995), “Cosmopolitan Democracy An Agenda for New Wold Order”. Cambrige Plity Press
} 
asegurar la estabilidad regional. Y a la vez le sirvió para frenar el proyecto de Seguridad Europea encabezado por Francia.

En segundo lugar les permitió, fortalecer la seguridad europea occidental, y sur oriental. En tercer lugar, la campaña aérea sobre Kosovo y Serbia, confirmaron la dominación tecnológica, militar y política de Estados Unidos sobre la OTAN. Pues logró que ésta operara como una fuerza de ataque ofensiva. En cuarto lugar, la utilización del poder militar limitado, le posibilitó reforzar el nuevo orden político, social y económico en Europa, favoreciendo la globalización neoliberal.

La intervención armada, de Estados Unidos y de la OTAN, promovió la desintegración de Serbia y de la ex Yugoslavia socialista, lo que produjo un incremento de la influencia norteamericana y de los aliados de la Alianza en la región. Al respecto es importante tener en cuenta las declaraciones del presidente Clinton:

“...la estabilización en Europa Suroriental mediante la terminación de una década de represión y limpieza étnica en Kosovo. Llevó a la dianza de la OTAN a la victoria en una campaña aérea y llevó hasta allí a las fuerzas Internacionales de mantenimiento de paz.. Inició el Pacto de Estabilidad para fortalecer la democracia, el desarrollo económico y la seguridad en toda la región, y acelerar su integración en el resto de Europa y librar a Europa de una crisis de refugiados y fuente de conflictos permanentes..." 57

Lo que equivaldría a decir que el poder militar ya no posibilitaba el control político, ello, no es algo nuevo para los neorreal istas que inclusive sostienen que nunca lo hizo.

Sin embargo, algunos analistas internacionales y funcionarios sostienen que, la dificultad real para la utilización efectiva de la fuerza, "ésta obsoleta" y "que las estructuras internacionales" ya no pueden establecerse a través de la distribución de las capacidades de los Estados.

Si tenemos presente la idea de que, un actor, es poderoso si sus políticas afectan a otros, más de lo que éstos lo afectan a él, se demuestra no sólo la vigencia sino, también, a importancia de las capacidades de los Estados en la era de globalización. La distribución de las capacidades establece el poder, y el grado de poder, no puede clasificarse a partir de los resultados que se obtienen. En consecuencia el poder de las capacidades norteamericanas, tiene un impacto enorme en la política mundial, aunque ese no fuera el fin buscado, sus consecuencias inciden en el comportamiento de los otros Estados.

Estas capacidades hacen que Estados Unidos sea el único país más poderoso e influyente del planeta. Esta posición de privilegio, es consecuencia tanto de la desaparición de la Unión Soviética porque ya no existe como país, o grupo de países, con la capacidad de disputar la primacía norteamericana.

Estados Unidos no sólo cuenta con la supremacía estratégico-militar y con el liderazgo en tecnología científica, sino que, la hegemonía estadounidense, abarca los aspectos económicos, medios de comunicación, entretenimiento y cultura.

La superioridad del poder norteamericano hace que su participación, en el contexto internacional, sea necesaria como un requisito previo para mantener de su hegemonía. Circunstancia que es evidente, en especial, en el ámbito de lo estratégico militar y de la seguridad internacional.

La participación norteamericana en la guerra de Kosovo constituye una prueba de ello, ya que, sin su participación como líder, ningún otro país, incluyendo a la OTAN, estaba dispuesto a emprender la acción.

Esta circunstancia plantea una elección a los Estados Unidos y, además, evidencia la relación que existe entre la política interna y la política exterior. Decidir entre la asunción de la responsabilidad con el compromiso de velar por la seguridad internacional, o, si se presta mayor atención al ejercicio de un liderazgo que sea funcional a sus intereses vitales y alcanzar la legitimación internacional, es algo que tiene difícil solución.

\footnotetext{
${ }^{57}$ Clinton W. J. Ibídem, pág. 3
} 


\section{El compromiso internacional norteamericano}

Desde la perspectiva neorrealista se cree que la necesidad de control aumenta en proporción al grado de interdependencia que tienen los Estados. Cuanto más interdependencia exista entre los actores internacionales mayor será la necesidad de contar con los actores polares del sistema internacional.

“...En un mundo multipolar, los Estados a menudo reúnen sus recursos con el objeto de llevar a cabo sus intereses. Miembros más o menos iguales abocados a empresas cooperativas deben buscar un común denominador para sus políticas. Se arriesgan a hallar el común denominador más bajo y terminar así en el peor de los mundos posibles. En un mundo bipolar, los líderes de las alianzas elaboran sus estrategias según sus propios cálculos de interés. Las estrategias se planean más para enfrentar al adversario que para satisfacer a los aliados..." 58

El presidente Clinton, al principio de su mandato presidencial, fue criticado por postergar la política exterior deliberadamente, pues concentró sus recursos en materializar su promesa sobre cuestiones internas principalmente de economía, de sistema de seguridad social y de salud.

Sin embargo esta actitud cambió, a causa de las constantes criticas recibidas en el sentido por no alentar una política exterior resuelta a cumplir con los compromisos tomados en materia de seguridad. Por eso sus principales aliados juzgaban su política exterior como débil.

La percepción, de los aliados europeos, sobre la conducta exterior norteamericana, cambió a partir de Dayton y Kosovo. A partir de allí la Casa Blanca se mostró resuelto a asumir el liderazgo en política exterior. Los estrategas creyeron prioritario: 1) lograr una ampliación de la OTAN, 2) solucionar o neutralizar la inestabilidad de los Balcanes, 3) profundizar la relación con Rusia. Todas, cuestiones que presentaban serias dificultades para el diseño de una estrategia que les permitiera atenderlos de forma simultánea. El presidente Clinton manifestó al respecto:

"Mientras América se ocupa de su reconstrucción interior, no debemos retroceder ante los retos de este nuevo mundo, ni desperdiciar sus oportunidades. Junto con nuestros amigos y aliados, trabajaremos para configurar el cambio, al que de otro modo sucumbiremos. Actuaremos cuando se produzca un desafío a nuestros intereses vitales, 0 a la voluntad y conciencia de la comunidad internacional: con la diplomacia pacífica cuando sea posible, con la fuerza cuando sea necesario." 59

Pero la guerra de Kosovo permitió que se pudiera aplicar una estrategia capaz de articular y controlar las tres cuestiones básicas planteadas por la Administración Clinton para Europa, eran, también, cuestiones que hacían cada vez más viable la implementación de su geoestrategia en el extremo sur-oriental de Europa del Este.

En consecuencia, es posible establecer que, en la guerra de Kosovo, hubo una convergencia entre el interés nacional y la necesidad de control de la región que protegen los Estados Unidos, y que son resultado de las obligaciones que surgen como consecuencia su posición privilegiada en el sistema internacional $y$, de los niveles aceptables de control tan indispensables para concretar su geoestrategia.

Si se analiza la conducta oficial de la Administración Clinton, se puede establecer una interrelación ente las cuestiones domésticas y la política exterior; interrelación que se confirma por las manifestaciones del vicepresidente Al Gore, al definir las pautas para asegurar la prosperidad dentro del país:

\footnotetext{
${ }^{58}$ Waltz N. Kenneth. Op. cit., pág. 24

${ }^{59}$ Clinton W.J. "Extracto del discurso de toma de posesión”. Enero 1993
} 
“...lo más importante sería asegurar la continuidad de la prosperidad dentro del país mediante el mantenimiento de la estabilidad en el exterior. Para ello, establecía, por un lado, la exigencia de seguir ayudando a los aliados a resolver sus dificultades financieras internacionales y, por otro, la obligación de mantener la seguridad de Estados Unidos y velar para que las fuerzas militares siguieran siendo fuertes y capaces..."'"60

El liderazgo norteamericano, en política exterior $y$, en especial, dentro de la OTAN, es producto de la ventaja que le brinda una alta concentración de poder, que en términos de seguridad hace que en la Alianza Atlántica no exista una verdadera interdependencia entre sus miembros asociados y que, en general, sean los europeos quienes dependan más del respaldo y garantías norteamericanas.

Por otro lado, esta desproporcionada concentración de poder junto con la desigual interdependencia entre las potencias aliadas occidentales generó, en los Estados Unidos, un interés encumbrado en el ejercicio del control y una capacidad superior para llevarlo a cabo sobre asuntos internacionales.

Esta situación preocupó a sus aliados de la OTAN, que a pesar de una proclamada solidaridad, el mismo día en que se rindió Milosevic, anunciaron sus intenciones de convertir a la Unión Europea en una potencia militar independiente. Oficialmente declaraban:

“...la Unión debe tener la capacidad de actuar con autonomía, apoyada con creíbles fuerzas militares, los medios para decidir usarlas, y la disposición de hacerlo, los medios para responder a crisis internacionales, sin prejuicio de las acciones de la OTAN..."

La preocupación de las principales potencias europeas evidenció que la confianza y cooperación con Estados Unidos tenía límites, y que, para asegurar niveles aceptables de autonomía, debían tener un poder defensivo estratégico poderoso, capaz, no sólo, de defender sus intereses internacionales, sino de permitirles competir con los norteamericanos.

En la situación descripta precedentemente existe una correlación con la visión del siguiente axioma del neorrealismo:

"Si los miembros de un reino anárquico están en una situación de interdependencia escasa, la concentración del esfuerzo destinado a lograr los propósitos comunes resulta menos necesaria. Las operaciones de importancia clave son las de control, y no las de regulación precisa, y las de prevención, más que las de coordinación..." ${ }^{62}$

\section{Estados Unidos y Kosovo: ¿Un modelo de decisión para conflictos similares?}

En la guerra de Kosovo el supuesto sistema multilateral se halla controlado por los Estados Unidos y por las principales potencias polares occidentales y no por las Naciones Unidas, esencia de un verdadero sistema multilateral.

Los Estados Unidos y sus principales aliados, quienes intervinieron militar y económicamente y, además, establecieron los términos del cese de las hostilidades con Serbia durante la guerra, y sólo una vez que se acordó la forma y las condiciones para el acuerdo, se dio intervención al Consejo de Seguridad de la ONU; que sirvió, lisa y llanamente, para legitimar la actuación militar de la Alianza.

“Dada una distribución del poder mundial muy desigual, algunos Estados, por medio de la manipulación de a amenaza de la fuerza, son capaces de moderar internacionalmente el uso de la fuerza de otros....63

\footnotetext{
${ }^{60} \mathrm{Al}$ Gore, Dannheisser, 2000

${ }^{61}$ North David "DESPUÉS DE LA MATANZA: LECCIONES POLÍTICAS DE LA GUERRA DE LOS

BALCANES”. WSWS.ORG. 1999. Pág. 4

${ }^{62}$ Waltz. K. Op. cit., pág. 305

${ }^{63}$ Waltz N. Kenneth. Ibídem, pág. 305
} 
Las premisas neorrealistas que demostraron su validez en el conflicto de Kosovo, ya que sirven para reconocer y gestionar conflictos de similares características por parte de Estados Unidos y de las potencias polares, son las siguientes:

Lograr la legitimación del intervensionismo justificándolo en nombre de causas justas, mediante la utilización de los Derechos Universales del Hombre.

Manipulación del sistema multilateral de las Naciones Unidas por parte de las potencias polares, revalorizando las potencialidades de jurisdicción de la OTAN, en detrimento del Consejo de Seguridad.

Promover ayuda y asistencia a los Estados que acepten los ideales y valores democráticos, proveyéndolos de recursos tales como servicios, equipos y entrenamiento militares, especialmente, estadounidenses.

Acceder de manera más fácil y económicamente más beneficiosa en regiones de accesos críticos, a través de programas de ayuda en seguridad, promoviendo, a la vez, alianzas funcionales a su geoestrategia.

Asistir a los países necesitados con programas sólidos de seguridad internacional fortalece su liderazgo en política exterior y aumenta la confianza y cooperación de sus aliados y amigos.

Estas premisas conforman el modelo de intervención de las potencias polares y seguirá vigente mientras continúen las crisis, en los Estados débiles y periféricos y, persistan los debates jurídicos, morales, políticos y militares, dentro de las Naciones Unidas para reaccionar ante conflictos intra-estatales.

En definitiva lo que puso en evidencia el conflicto de Kosovo, fue que a partir de la finalización de la Guerra Fría; y con el surgimiento de conflictos étnicos y religiosos produjo un retroceso en el sistema multilateral. Lo que parecería revitalizar la siguiente creencia neorrealista:

"Prohibir el uso de la fuerza por medio de la amenaza de usarla, oponer la fuerza a la fuerza, influir sobre políticos de los Estados por medio de la amenaza o el uso de la fuerza: éstos han sido y siguen siendo los más importantes medios de control en asuntos de seguridad ..." ${ }^{64}$

${ }^{64}$ Waltz N.Kenneth. Ibídem., pág. 305 
Relaciones Internacionales, número 23/2002

Insituto de Relaciones Internacionales (IRI). U N LP

\section{Conclusión:}

Cuando nos preguntamos sobre la motivación de Estados Unidos para su intervención en el conflicto, debemos cuestionarnos sobre su necesidad de comprometerse en la guerra.

Desde la guerra fría tuvo lugar una estrecha interdependencia entre Estados Unidos y las principales potencias de la OTAN, lo que ha llevado a Norteamérica, a considerar los acontecimientos de otros Estados, como si sucedieran dentro de su jurisdicción. Más aún, si en la región se hallan comprometidos sus intereses vitales.

Simultáneamente, se produjo una concentración del poder, que permitió a las potencias polares, ubicadas en el extremo, tener un mayor anhelo de ejercer el control y una mayor capacidad para realizarlo. Pero, también, surgió una necesidad constante, en los estrategas y funcionarios estadounidenses por lograr un consenso doméstico e internacional, para alcanzar la legitimación y establecer una sólida política exterior de intervención.

Cuando se trata de hallar una explicación razonable sobre la participación norteamericana, basada en las premisas de distintas teorías analizadas, comprobamos que la TEl resulta insuficiente, considerando que:

A pesar de ser Estados Unidos una de las potencias económicas importantes, no fue suficiente, para lograr establecer el margen de libertad político necesario que le evitara recurrir a la cooperación y a la legitimación internacional.

Los atributos económicos y militares de Estados Unidos hubiesen sido suficientes para que emprendiera de manera autónoma la intervención armada, sin otra justificación que el cumplimiento de sus objetivos económicos, sin considerar las opiniones de los actores internacionales involucrados.

La superioridad de las capacidades económicas, tecnológicas y militares norteamericanas, despertaron sospechas y suspicacias en el resto de los actores internacionales. Esta situación motivó que, la Administración Clinton, enfrentara serios cuestionamientos domésticos e internacionales a sus acciones en política exterior.

Una de las circunstancias que complicaron la supuesta actuación imperialista de Estados Unidos de manera unilateral fueron las cuestiones económicas. Lo que evidencia, y no tiene en cuenta la TEI, es que previamente o simultáneamente a sus acciones, la Administración Clinton, debió elaborar un discurso legitimador que permitiera obtener un consenso interno e internacional a su política exterior.

La TEl, considera que la competencia entre las potencias capitalistas provoca una desestabilización del "orden internacional", y que ésta es un producto del deseo de los Estados para aumentar su poder. Pero, en la guerra de Kosovo, se dio una alianza entre los países emergentes que pertenecían a distintas culturas y religiones.

El conflicto no fue originado por un Estado capitalista y, además, sus causas tienen que ver con cuestiones religiosas, étnicas, políticas y culturales.

Respecto a la teoría del realismo clásico, se observan las siguientes falencias, puesto que:

En la guerra de Kosovo no estaba en juego la propia seguridad de Estados Unidos ni su supervivencia, así como tampoco su hegemonía. Los cuales son, según el realismo, los objetivos básicos que explican la conducta de los actores internacionales.

Esta crisis constituyó un conflicto de orden interno que involucró a la población civil, y ocasionó la injerencia de otros actores internacionales. Circunstancia que permite ver cómo la línea, de lo que divide al ámbito de la política exterior, se diluye y se confunde.

Las diferencias entre la política doméstica y exterior no se basan en el uso de la fuerza sino en las diferencias de sus estructuras, lo que permite comprender las razones por las cuales una gran potencia militar, necesita de la legitimación internacional para sus intervenciones armadas.

En esta guerra hubo armonía de intereses entre las potencias polares, lo que contradice al realismo, que considera que ella no puede existir entre los actores internacionales.

Estados Unidos y la Unión Europea deberían haber intervenido de manera decidida y contundente para reestablecer el status quo en la región. La intervención armada se hubiera realizado sin escatimar medios, teniendo en cuenta que el poder de la Alianza maximizadora, 
que constituye la OTAN, era superior al poder defensivo y económico de Serbia. Sin embargo, Estados Unidos y los miembros de la OTAN, necesitaron una legitimación internacional. Estados Unidos tuvo que fundamentarla para procurar un consenso ante la mayoría de su población, así como también ante los miembros de la OTAN, las Naciones Unidas y la opinión mundial.

La Administración Clinton, tuvo en cuenta la estructura interna de la sociedad norteamericana, en especial la de su estructura gubernamental. Este hecho indica la limitada autonomía de decisión de los estrategas encargados de diseñar la política exterior.

Al presidente Clinton también le preocupó que, a consecuencia de la crisis, se generará un aumento en el déficit fiscal que le impidiera cumplir con su promesa electoral, la que consistió en aumentar el presupuesto del área asistencial.

Un verdadero practicante de la "Realpolitikit" hubiera alentado las acciones terrestres, sin importarle sus consecuencias humanitarias, y hubiese contado con un alto grado de autonomía doméstica para llevar adelante sus decisiones.

Estados Unidos fundamentó su intervención armada en la defensa de los valores universales del Hombre y de la cultura occidental, según los partidarios del realismo, la defensa de los derechos humanos universales, no es conveniente, pues, además de intervenir en los asuntos internos de otras naciones, causa fricción con los intereses de la seguridad nacional y debilitan los intereses estratégicos y comerciales.

En cuanto a las premisas de la interdependencia, no logran responder satisfactoriamente los siguientes hechos:

No hubo durante la guerra en Kosovo un cumplimiento riguroso del Derecho Internacional Público (DIP), y su implementación presentó contradicciones, pues tanto albanos-kosovares y serbios, se sirvieron del mismo para fundamentar y legitimar sus reclamos.

Estados Unidos junto con los restantes miembros de la OTAN, justificaron su intervención armada, en la necesidad de poner fin a la violación de los derechos humanos. Sin embargo, la Alianza Atlántica, llevo a cabo la intervención violando los mecanismos y procedimientos amparados por el DIP, norma que decía defender (Carta de la ONU, Artículo 24-1)

A pesar de existir una confluencia entre los objetivos y la cooperación de los principales miembros de la OTAN y de los restantes actores internacionales, la guerra, también reflejó la ausencia de un estrecho vinculo entre los miembros de la Alianza Atlántica, puesto que existieron discrepancias entre la presunta homogeneidad impuesta por la interdependencia y la diversidad internacional.

La participación estadounidense no puede comprenderse siguiendo los preceptos de la interdependencia, ya que la estrategia de la OTAN obedeció a los lineamientos de Estados Unidos, con la complacencia aceptada o resignada de los países miembros de la Unión Europea.

La intervención norteamericana en Kosovo, estuvo lejos de querer una verdadera interdependencia global, porque si esta fuese su meta, hubiese basado su intervención humanitaria a través de las Naciones Unidas, específicamente, con la autorización del Consejo de Seguridad.

Durante la guerra la insistencia de Estados Unidos provocó que Rusia no desempeñara un papel más significativo. A pesar de que los funcionarios rusos llevaron a cabo los contactos diplomáticos antes y durante la conferencia de Ramboullet.

Contemporáneamente a la guerra se produce un estancamiento en el acuerdo para el desarme START-2, porque el Parlamento ruso no estaba dispuesto a aprobarlo.

La crisis demostró cómo los efectivos de la OTAN, funcionarios y administradores internacionales, son más importantes para alcanzar la estabilidad de los Balcanes que la misma población nativa.

Si bien, existe la creencia de que no puede comprenderse la realidad internacional a través de una única teoría, sino que, por el contrario, dicha comprensión se facilita más si se utilizan como herramientas las categorías primordiales de cada una de ellas. Sin embargo, en esta tesis se considera que, el neorrealismo, posibilita una explicación más completa del conflicto, por las siguientes razones:

El realismo estructural describe al sistema internacional como constituido por dos niveles: en el primero, está la estructura internacional y en el segundo, las unidades interactuantes. La 
estructura internacional condiciona las relaciones políticas que se dan entre sus miembros. Por esta razón, el enfoque de Waltz, permite llegar a una interpretación más acertada sobre lo que sucedió y sucede en Kosovo.

El neorrealismo propone que la política internacional sea mas que la suma de las políticas exteriores de los estados. Ello puede apreciarse en la conducta de Estados Unidos y de los restantes actores que intervinieron en el conflicto ya que, en la guerra, hubo una correlación entre las siguientes categorías de investigación, que a continuación se detallan:

\section{Sistema y decisión, que implica, interés y poder:}

La Administración Clinton creyó que, si no se involucraba en la guerra, se exponía a que las relaciones de Estados Unidos y la Unión Europea se resintieran iniciándose un proceso de debilitamiento que podía repercutir en la fuerza de la OTAN, esta situación hubiera profundizado la tensión existente entre Grecia y Turquía, provocando una intervención rusa.

La no-injerencia norteamericana, hubiera perjudicado su geoestrategia en relación con la necesidad de ampliar a la OTAN, además de no lograr una política junto con los europeos hacia Rusia, Oriente Próximo e Irán, el terrorismo, los Derechos Humanos, el crimen organizado y el Medio Ambiente.

El liderazgo norteamericano fue ejercido no sólo en el eje estratégico-militar, sino también en el tecnológico y económico, así como también en las comunicaciones, los entretenimientos y la cultura. La superioridad del poder norteamericano hizo que su participación fuera un requisito previo en la guerra, ya que, sin su liderazgo la OTAN, no hubiera estado dispuesta a emprender la acción.

Percepción y realidad:

La percepción, de los aliados europeos, sobre la conducta exterior norteamericana, cambió con Dayton y Kosovo. A partir de allí la Casa Blanca se mostró más resuelta a asumir el liderazgo en política exterior. Lo que se tradujo en: 1) ampliación de la OTAN, 2) solucionar o neutralizar la inestabilidad de los Balcanes, 3) profundizar la relación con Rusia.

Estrategia de comportamiento entre los miembros de la Alianza Atlántica:

"Cooperación y conflicto".

Cooperación: El liderazgo norteamericano en política exterior y, en especial, dentro de la OTAN, es resultado de una alta concentración de poder, que en términos de seguridad hace que en la Alianza Atlántica no exista una verdadera interdependencia entre sus miembros.

Conflicto: La alta concentración de poder por parte de los Estados Unidos preocupó a los demás miembros de la OTAN, pues a pesar de una proclamada solidaridad, anunciaron el mismo día de la victoria sobre Milosevic, su intención de convertir a la Unión Europea en una potencia militar independiente.

Norma y ventajas:

La guerra de Kosovo demostró que el supuesto sistema multilateral fue controlado por los Estados Unidos y por las principales potencias occidentales y no por las Naciones Unidas, esencia de un verdadero sistema multilateral.

Estados Unidos y sus principales aliados, intervinieron militar y económicamente, establecieron los términos del cese de las hostilidades con Serbia, y sólo después que se acordó la forma y las condiciones para el acuerdo, se dio intervención al Consejo de Seguridad de la ONU, que les sirvió, para legitimar la actuación militar de la Alianza Atlántica.

Las consideraciones estratégicas fueron vitales para decidir la intervención armada de Estados Unidos y la OTAN, pero, para que la participación directa fuera legitimada y deseada no sólo por los ciudadanos norteamericanos sino también por la opinión pública mundial, la misma fue justificada con el argumento de que Estados Unidos y sus aliados actuaban en defensa de valores morales y humanitarios.

La propaganda en los medios masivos de comunicación contribuyó a reforzar esta creencia, ya que las imágenes transmitidas por la televisión, acerca del destino de miles de Kosovares, horrorizaron, y generaron una pulsión positiva, en la mayoría de los ciudadanos estadounidenses, pulsión que supo ser canalizada por los funcionarios políticos a favor de la estrategia de intervención propiciada por el presidente Clinton. 
Relaciones Internacionales, número 23/2002

Insituto de Relaciones Internacionales (IRI). U N LP

Finalmente, Kosovo ha permitido conocer, en términos generales, la forma en que Estados Unidos instrumentó sus capacidades, ideando los medios más eficaces: diplomáticos, culturales, económicos y militares, para asegurar sus intereses geopolíticos.- 


\section{Bibliografía}

Amin Samir, (1997) “Los desafíos de la mundialización”. XXI. México.

Blackburn Robin, (2000) "Kosovo: la guerra de expansión de la OTAN". New Left Review. Akal, Madrid.

Brzesinski Zbigniew, (1998) “El gran tablero mundial”. Barcelona. Piados.

Chandler David,(2000) "El protectorado bosnio y las implicaciones para Kosovo" Madrid. New Left Review. Akal.

Cohen, S. W., (1999) "Prevención de conflictos- Operaciones militares en tiempo de paz". Department of State, IIP, U. S. Foreign Policy Agenda, December .

Cleland, Max. (1999) “Mantener nuestras prioridades al mismo tiempo que mantenemos la Paz". Departament of State, IIP, U.S. Foreign Policy Agenda, December,

Clinton, W.J., "Una guerra justa y necesaria". Traducción de un ensayo publicado originalmente en el The New York Times, el 23 de mayo de 1999.

Dallanegra Pedraza L., (1998) “El Orden Mundial del Siglo XXI”. Bs. As. De la Universidad.

Dougherty James E. - Pfaltzgraff Robert L., (1993) “Teorías en pugna en la Relaciones Internacionales". Bs. As. Grupo Editor Latinoamericano.

Doyle Michael W. (1965) "Empires". Ithaca, New York, Cornell University Press, Duroselle Jean-Baptiste, (1998) "Todo imperio perecerá. Teoría sobre las relaciones internacionales". México. Fondo de Cultura Económica. mayo.

Fernández de Loaysa, (1999) "La OTAN y la crisis de Kosovo". Revista Defensa, N²53:

Fisk Robert, "La discutible labor de los periodistas en Kosovo", El País, 30-6-99.

García, Dionisio, (1999) "Ataque contra Yugoslavia. El Dispositivo Terrestre". Revista Soldiers Raids, $\mathrm{N}^{\circ} 46:$ Julio.

Gilpin Robert (2000) "The Challenge of Global Capitalism. The world Economy in the XXI century". Princenton: Princenton University Press.

Granell Francesc, (1997) "Conflicto y cooperación entre Europa y Estados Unidos". Revista Exterior. 60, XI- noviembre / diciembre.

Habermas Jurgen, (2000) "El Estado-nación europeo y las presiones de la globalización". Madrid. New Left Review. Akal.

Habermas Jurgen, (1988) "Problemas de Legitimidad en el Capitalismo Gardío". Buenos Aires. Grupo Editor Latinoamericano.

Halliday Fred, (1997) "Gobernabilidad global: perspectivas y problemas". Revista Internacional de Filosofía Política. Madrid, N 9, junio.

Held D. (Comps.), (1995) "Cosmopolitan Democracy An Agenda for New Wold Order". Cambrige Plity Press. 
Hobson J. A. (1965) "Imperialism: A Study". Ann Arbor, University of Michigan Press.

Lenin V. I., (1939) “Imperialism: The Highest Stage of Capitalism". International Publishers, New York.

Kennan George, (1989) "La Guerra Fría Ha Terminado". Conferencia de G. Kennan ante el Comité de Relaciones Exteriores del Senado de los Estados Unidos.

Kennedy Paul, (1994) “Auge y Caída de las grandes potencias” Barcelona. Plaza \& Janes.

Keohane Robert, "Instituciones Internacionales y Poder Estatal". Bs As. Argentina. . Gel 1997.

Kissinger Henry, (1995) “La Diplomacia”. México, Fondo de Cultura Económica. Krasner Stephen, (1989) "Conflicto Estructural: El tercer mundo contra el Liberalismo Global". Buenos Aires, Gel. Pres.

Magdoff, Harry, (1969) “The Age of Imperialism”. Cap. I y V. New York: Monthly Review

Morgenthau H.,(1963) “La lucha por el Poder y la Paz". Buenos Aires. Sudamericana.

Morgenthau H., (1986) "Política entre las naciones. La lucha por el poder y la paz". Buenos Aires, Grupo Editor Latinoamericano.

Powell Colin, con Joseph E. Pérsico, (1994) "MY AMERICAN JOURNEY". Nueva York: Random House.

Pérez Llana Carlos, (1998) “El Regreso de la Historia: La Política Internacional durante la Post Guerra Fría 1989-1997". Buenos Aires. Sudamericana.

Raymond Aron, (1985) “Paz y Guerra entre las Naciones”. Buenos Aires, Sudamericana.

Resolución 1160 “Consejo de Seguridad de las Naciones Unidas”. 1998

Resolución 1244 “ Consejo de Seguridad de las Naciones Unidas”. 1999.

Rosenau James, N. (1999) “Acerca de la Frontera interna y externa: El gobierno en un mundo turbulento". Cambridge University Press.

Rosenau James N., (1984) “A PRE-THEORY REVISITED: WORLD POLITICS IN A ERA OF CASCADING INTERDEPENDENCE", Internacional Studies Quarterly, Vol. 28, Número 3, septiembre.

Sohr Raúl, (2000) “Las Guerras que nos esperan”. Santiago de Chile.

Sorel Albert, 1997 "Europe under the Old Regime", Trad. Por Francis H. Herrick. Los Angeles: Ward Ritchie Press.

Waltz Kenneth, (1998) "Teoría de la Política Internacional".Buenos Aires. Grupo Editor Latinoamericano.

Waltz Kenneth, (1970) “El Hombre, el Estado y la Guerra”. Buenos Aires. Nova.

Waltz Kenneth, (1994) "El nuevo orden mundial". Buenos Aires. Revista América Latina Internacional. Vol. $1 \mathrm{~N}^{\circ}$ 2, Otoño. Área de Relaciones Internacionales de FLACSO. 


\section{Anexos}

\section{Anexo 1}

Las categorías de análisis especificadas por Jean-Baptiste Duroselle (1998), en su obra “Todo imperio perecerá" . México. Fondo de Cultura Económica, pp. 142 a 145. Es posible eval uar las cuestiones mencionadas para el caso Kosovo.

\section{Fuerzas militares disponibles de inmediato:}

El libro no detalla información sobre el poderío militar disponible en la guerra de Kosovo; las inferencias se extrajeron de fuentes periodísticas especializadas (Revista "Soldiers Raids" Madrid julio $1999 \mathrm{~N} \circ 46$ p.p. 19-22) desde donde se describen tentativamente las fuerzas norteamericanas que se hallaban en Europa, serían las disponibles para su empleo inmediato junto con los efectivos de la OTAN. Las que conformaron la Fuerza Kosovo o KFOR, integrada por unos 50.000 hombres hacia finales de mayo.

En los setenta y nueve días, que duró la guerra de Kosovo, se utilizaron 1.055 aviones, de los que 730 correspondían a Estados Unidos. Antes del comienzo de la ofensiva aliada, la OTAN, ya tenía instalado en Macedonia 12.000 efectivos que formarían parte de la KFOR; cifra suficiente, si Milosevic hubiera autorizado su ingreso en Kosovo.

En Macedonia estaba la Fuerza Preventiva de Naciones Unidas o UNPREDEP, que contaba con personal norteamericano. Estados Unidos con la finalidad de preparar la invasión terrestre ejerció una presión sobre Serbia, instalando en Albania la denominada Fuerza Táctica "HAWK"(Halcón) integrada por unos 2000 hombres junto con 24 helicópteros AH - 64 Apache y $26 \mathrm{UH}-60$ Blackhawk.

En la fuerza de tarea "HAWK" también formaba parte un batallón de Artillería, integrado por 19 lanzacohetes, para atacar las posiciones serbias en Kosovo junto con los helicópteros Apache.

La OTAN formó la Fuerza Albania o AFOR integrada por efectivos de los distintos países miembros de la Alianza, que sumaban cerca de 7.000 hombres.

\section{Duración estimada de la Guerra}

La prolongación en el tiempo está directamente relacionada al poderío de los beligerantes. Si la guerra es breve se debe, en teoría, al poderío superior de los atacantes y a la incapacidad de la nación más débil de conseguir aliados en el exterior.

Las fuerzas serbias, en Kosovo, ascendían a 40.000 efectivos, pero dicho número había aumentado al sumarse las fuerzas paramilitares. La cifra estimada de efectivos serbios movilizados ascendería a los 100.000 hombres.

\section{El potencial}

El concepto de potencial refiere al tiempo de disposición del incremento del poderío bélico y, en este sentido, los Estados Unidos y sus aliados de la OTAN, superaban ampliamente al potencial de Serbia. Tanto en los aspectos financieros, logísticos, demográficos, como en el industrial y el tecnológico.

Sin embargo, Serbia aventajaba a los miembros de la OTAN en lo referido a la disposición de los ciudadanos, de aceptar un alto costo en vidas humanas. 


\section{Los riesgos eminentes de la acción}

Las fuerzas serbias de Kosovo estaban principalmente desplegadas en torno a las fronteras de Albania y Macedonia, donde habían establecido posiciones defensivas y minas en sus accesos. Las tropas regulares serbias de 40.000 hombres, habían preparado, meses antes del ataque, diversas maniobras para la defensa de las fronteras.

Luego del comienzo de la operación Fuerza Aliada, se efectuaron ataques intermitentes contra poblaciones en el interior de Albania, en persecución de guerrilleros kosovares. A las unidades serbias, hostigadas por aviones de la Alianza, se le cortó la comunicación por tierra, para aislarlos del resto del país. La logística serbia fue afectada por la OTAN, que le había destruido numerosos vehículos de combate, tanques y piezas de artillería.

Como consecuencia, la capacidad de resistencia y operatividad del ejército serbio quedó muy disminuida, con la circunstancia agravante, de que más de la mitad de su tropa eran reservistas, es decir, con escaso entrenamiento militar. 


\section{Anexo 2}

Principales diferencias entre serbios y albano Kosovares

Albano Kosovares

\section{Población}

En Kosovo existía dos millones de personas. Antes de la salida masiva de refugiados, los albano kosovares superaban el $90 \%$ de la población.

\section{Idioma}

El idioma de los albano-kosovares tiene raíces indoeuropeas.

\section{Política}

En 1974, Kosovo poseía autonomía y derecho a voto en el Consejo Federal de Yugoslavia.

\section{Religión}

La mayoría de la población albanoKosovar son musulmanes.

\section{Historia}

Los albano-kosovares descienden De losilirios, que habitaban Kosovo desde tiempos remotos.
Serbios

Antes de la II Guerra Mundial la población serbia en Kosovo, ascendía aproximadamente a la mitad. Pero las migraciones internas del campo a la ciudad y el crecimiento de la tasa de natalidad albano-kosovar incidieron en la densidad de la población de la provincia.

La lengua serbia tiene origen eslavo.

Slobodan Milosevic suprime la autonomía de Kosovo en 1989, imponiendo un régimen militar en la provincia.

Gran parte de los serbios profesan la religión cristiana ortodoxa.

Los serbios recuperan Kosovo en 1912, durante la I Guerra Mundial, cuando Turquía es vencida por los Aliados, dándose fin a 500 años de dominación del Imperio Otomano. 


\section{Anexo 3}

\section{Acuerdo de Paz de la Guerra de Kosovo: “Exigencias y condiciones más relevantes"}

- Cese inmediato y veificable de la violencia y la represión en Kosovo.

- Retirada verificable de Kosovo de todas las fuerzas militares, policiales y paramilitares (siete días para una retirada total y 48 horas para las armas de defensa antiaérea)

- Despliegue en Kosovo, bajo bandera de la ONU, de una presencia internacional eficaz, civil y de seguridad, que actuará como se decida según el capítulo VII de la Carta de la ONU.

- La presencia internacional de seguridad, con una participación fundamental de la OTAN, se desplegará bajo un mando unificado y facilitará el regreso de los refugiados y desplazados de la RFY.

- Instauración de una Administración provisional en Kosovo, como parte de la presencia internacional civil, bajo la cual el pueblo kosovar podrá gozar de una autonomía sustancial dentro de la RFY.

- Tras la retirada, cierto número de personal yugoslavo cientos y no miles podrá regresar para : a) coordinarse con la misión civil internacional y la fuerza de seguridad internacional; b) localizar los campos de minas; c)mantener la vigilancia del patrimonio histórico serbio; d)controlar los pasos fronterizos. 